University of Rhode Island

DigitalCommons@URI

Open Access Master's Theses

1981

\title{
AN INDUSTRIAL DEVELOPMENT STRATEGY FOR CENTRAL \\ FALLS, RHODE ISLAND
}

Donald Silverson

University of Rhode Island

Follow this and additional works at: https://digitalcommons.uri.edu/theses

\section{Recommended Citation}

Silverson, Donald, "AN INDUSTRIAL DEVELOPMENT STRATEGY FOR CENTRAL FALLS, RHODE ISLAND" (1981). Open Access Master's Theses. Paper 497.

https://digitalcommons.uri.edu/theses/497

This Thesis is brought to you for free and open access by DigitalCommons@URI. It has been accepted for inclusion in Open Access Master's Theses by an authorized administrator of DigitalCommons@URI. For more information, please contact digitalcommons-group@uri.edu. 


\author{
AN INDUSTRIAL DEVELOPMENT STRATEGY \\ FOR CENTRAL FALLS, RHODE ISLAND \\ BY \\ DONALD SILVERSON
}

A THESIS-PROJECT SUBMITTED IN PARTIAL FULFILLMENT OF THE REQUIREMENTS FOR THE DEGREE OF MASTER OF ARTS

IN

COMMUNITY PLANNING AND AREA DEVELOPMENT 


\section{MASTER OF ARTS THESIS-PROJECT \\ $\mathrm{OF}$ \\ DONALD SILVERSON}

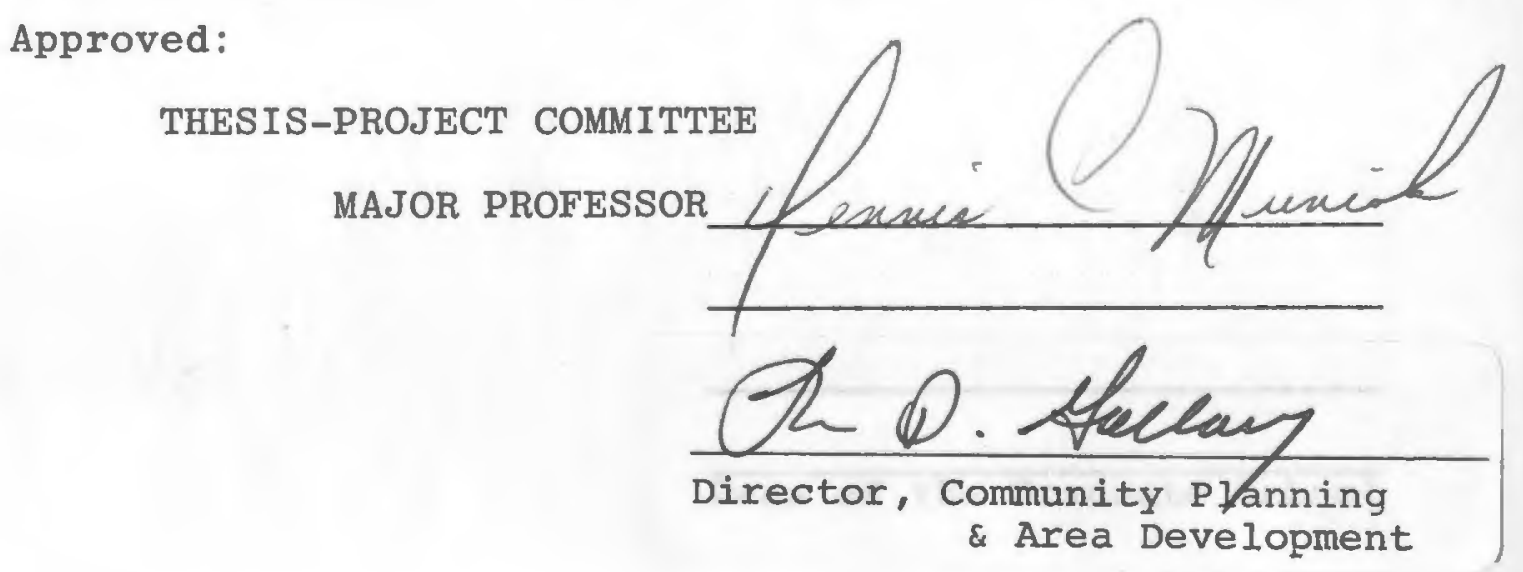

UNIVERSITY OF RHODE ISLAND

1981 
TABLE OF CONTENTS

Chapter

I. HISTORICAL DEVELOPMENT AND DESCRIPTION

OF LOCAL ECONOMY . . . . . . . . . . . . . . I

Early Development

Economic Decline

Description of Local Economy

Manufacturing

Market Area for Products

Current Trends in Local Industry

II. PUBLIC INVOLVEMENT IN ECONOMIC DEVELOPMENT . . . , 21

Federal and State Programs

Financial Assistance

Technical Assistance

Summary

III. LOCAL INDUSTRIAL DEVELOPMENT . . . . . . . . . 37 Purpose and Scope of Program

Goals and Objectives

Elements of the Program

Research

Organization

Technical Support

Operational

Financial

Promotion

IV. OPPORTUNITIES FOR INDUSTRIAL DEVELOPMENT . . . . . 77

Market Analysis

Project Identification

Site Acquisition 


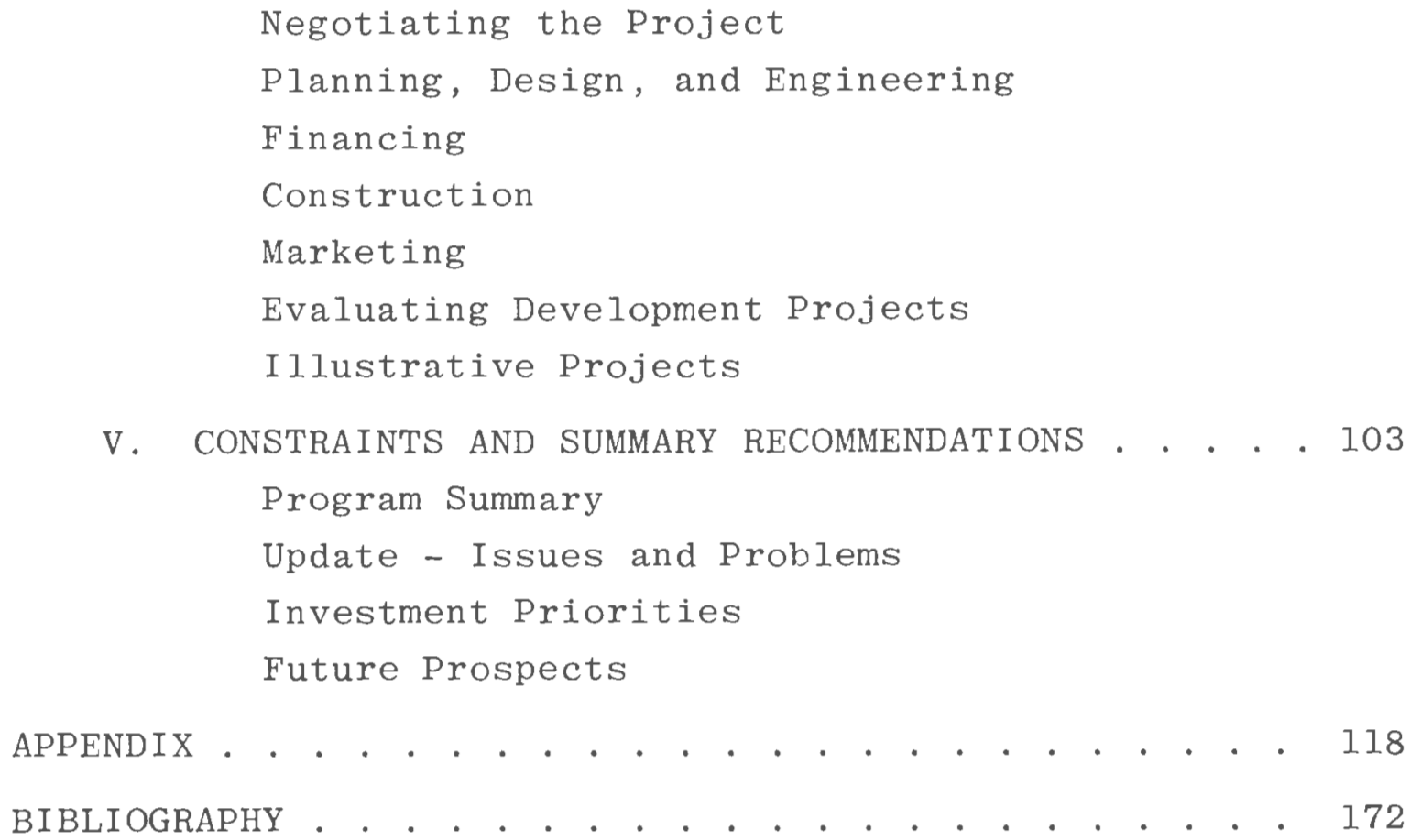




\section{LIST OF ILLUSTRATIONS}

Figure

3.0 Industrial Areas in Central Falls........ . Il

3.1 Vacant Land Zoned Industrial . . . . . . . . .57 December, 1980

3.2 Potential Expansion and Renovation Projects . . 58 August, 1980

3.3 Elements of Central Falls Industrial Development Program . . . . . . . . . . . . 


\section{LIST OF TABLES}

1. Covered Employment and Payrolls in Central

Falls Subject to Employment Security . . . . . .6

2. Major Products . . . . . . . . . . . . . . 8

3. Analysis of Land Zoned for Industry . . . . . . . 12

4. Central Falls: Number of Firms, Manufacturing Employment, and Payrolls . . . . . . . . 16

5. New Construction for Manufacturing in Central Falls - 1955-1977. . . . . . . . . . . 18

6. Wages and Taxes Per $\$ 100$ of Business Profit, By State............... . . . . . . 1

7. Index of Construction Costs for Major SMSA's . . .65

8. Average Cost of Electric Power, By Regions . . . .70

9. Public Assistance Used by New Plants . . . . . . .72

10. Manufacturers Survey Results - Question No. 1, Major Products . . . . . . . . . . . . . .137

11. Manufacturers Survey Results - Question No. 2, Sales Volume. . . . . . . . . . . . . . 139

12. Manufacturers Survey Results - Question No. 4 Number of Employees - Full or Part-Time . . . . 142

13. Manufacturers Survey Results - Question No. 4, Number of Employees VS Type of Firms . . . . . . 143

14. Manufacturers Survey Results - Question No. 5, Percentage of Employees by Municipality . . . . . 144

15. Manufacturers Survey Results - Question No. 6, Percentage of Employees per Shift . . . . . . . 144

16. Manufacturers Survey Results - Question No. 8, Age of Buildings. . . . . . . . . . . . . 146

17. Manufacturers Survey Results - Question No.9, Occupant Own/Lease . . . . . . . . . . . . . .147

18. Manufacturers Survey Results - Question No. 12, Needed Building Improvements . . . . . . . . .150

19. Rank of Needed Building Improvements . . . . . . . 151

20. Manufacturers Survey Results - Question No. 13, Operating Problems . . . . . . . . . . . . . 153

21. Manufacturers Survey Results - Question No. 15, Suggestions for City Support....... . . . 156 


\section{LIST OF TABLES (Continued)}

22. Average Annual Total and Manufacturing

Employment in Central Falls 1960 - 1980 . . . . 163

23. Central Falls Employed Workers by Broad

Occupational Category (1970 Census) . . . . . 164

24. Central Falls Manufacturing Firms . . . . . . . 164

25. Percent Distribution of Manufacturing

Employment by Industry Types in

Central Falls - March, 1980 . . . . . . . .165

26. Average Hourly Earnings of U. S. Production

Workers on Manufacturing Payrolls, By

Major Industry Group - 1977. . . . . . . . 166 


\section{ABSTRACT}

The City of Central Falls has approximately seventy (70) firms engaged in the manufacture and processing of raw materials into finished products. These firms represent a significant resource to the city in the form of jobs, tax revenues, and potential economic growth. The majority of the city's firms rely on export markets, with $74 \%$ of all products manufactured in the city being marketed outside Rhode Island. Therefore, Central Falls' industry brings new money into the Blackstone Valley and contributes to its stability and growth.

Recognizing the importance of this sector of the local economy, Mayor Richard B. Bessette enlisted his Division of Planning and Community Development (DPCD) to study the needs and concerns of the manufacturing community. A 1978 Survey of Manufacturers revealed that Central Falls has a diversified economic base due to a large number of small and medium-sized firms. The results of the survey also indicated that a significant portion (44\%) of the factories are over fifty (50) years old. Antiquated design and deterioration require that these buildings be renovated to reduce energy consumption, meet modern day shipping and receiving demands, and to solve space problems. 
Based on these results and other research on the condition of local industry, Central Falls must address the needs of the manufacturing community by identifying vacant and underutilized space in the city, assisting in the rehabilitation of existing industrial buildings, and improving streets, parking facilities, and traffic circulation in its industrial districts. In this report I have outlined an industrial development strategy to accomplish these improvements. The strategy consists of the following elements: technical and financial assistance, organizational development, special projects, and marketing and promotion.

Central Falls' Division of Planning and Community Development (DPCD) will play a significant role in the implementation of this strategy. DPCD will provide staff support, coordinate the allocation of public resources, including financing, and represent the city's interests in any negotiations. The strategy recommends the city increase involvement in local economic development through the Special Task Force for Industrial Development, The Blackstone Valley Chamber of Commerce, and the Second Pawtucket Industrial Foundation.

In addition to the elements mentioned above, the report recommends both short and long term investment strategies the city can adopt to pursue its economic 
development goals. Short term strategies include continued work with the Task Force, traffic circulation and parking improvements, educational and promotional efforts, and a feasibility study of a vacant industrial site. For the long term, the city should develop an Industrial Reinvestment Program, plan a development project with the Second Pawtucket Industrial Foundation, examine tax policies, formulate a more aggressive marketing effort, and establish a more formal development mechanism within municipal government.

A number of problems will act as constraints on the implementation of this strategy. These include a scarcity of suitable land, a poor image, and local government's inexperience and lack of commitment toward economic development. Given its fiscal problems and the importance of industry to the local economy, Central Falls should adopt a sound and consistent strategy to strengthen local industry. This is a necessary first step toward building a productive partnership with the private sector. 
CHAPTER I.

HISTORICAL DEVELOPMENT AND DESCRIPTION OF LOCAL ECONOMY 


\section{EARLY DEVELOPMENT}

Central Falls can trace its real beginnings back to the early 19th Century when Elisha Waterman converted the chocolate factory on the banks of the Blackstone River into a mill for spinning yarn. ${ }^{1}$ This event heralded the future development of the 1.27 square mile community into the most densely populated city in the nation by World War II. The settlement depended for its survival and growth on one industry - textiles. This industry tells the story of Central Falls over the last 180 years. During this period other manufacturing activities have developed, but only out of support of textile production.

During the first 50 years following Elisha Waterman's innovation, Central Falls grew steadily into a leading New England producer of cotton cloth, woolen products, and horsehair cushions. It is estimated that in $1860,1,059$ people were employed in the city's burgeoning textile industry. 2

Following the Civil War a new era of growth was to begin for the small city. By 1895, Central Falls supported 3,500 textile employees and a population approaching 16,000. 3

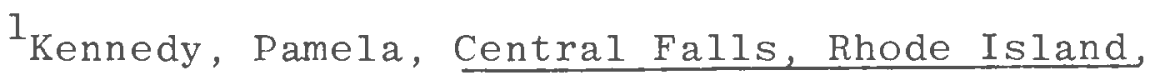
Statewide Historical Preservation Report, P-CF-1, (Providence, Rhode Island Historical Preservation Commission, 1978), p. 8

2 Ibid, p. 20

3 Ibid 
During this latter period the local population could no longer fulfill the labor requirements of the booming industry. A call for additional workers went out. The French-Canadians were the first to respond. As the new immigrants moved into the city, the older, better established Yankee groups moved out into the rural fringes. This process of immigration by new groups replacing older, more established immigrant populations has continued in the city until the present day.

By 1890, Central Falls had become a well-defined urban community surrounded by a growing rural-suburban setting. Yet it remained a part of the Town of Lincoln. As time passed, the divergent interests between the urban and rural areas became increasingly strained. In 1895, the question of the incorporation of Central Falls was put before the voters of Lincoln. They responded by voting overwhelmingly in favor of incorporation. 4

This separation was especially difficult. In addition to starting out with a debt, all surrounding undeveloped land was excluded from the new city. In the long run, this has made it impossible for Central Falls to experience the normal growth and development patterns of other urban areas. In effect, Central Falls was born a city full gorwn.

${ }^{4}$ Ibid, p. 39 
Rather than having an opportunity to expand and provide alternative residential and business developments, the city could only pack more of the same into the existing area.

ECONOMIC DECLINE

During the first twenty-five (25) years of independence, Central Falls continued to experience an era of prosperity and growth. Textile manufacturing increased, providing new employment opportunities for the city's rising population. But it was with this prosperity that future problems became evident, for the city lacked economic diversity. By 1920, textiles were Central Falls over 75 percent of the local labor force was engaged in textiles and textile related activities. ${ }^{5}$ The mass exodus of this industry during the coming decades was to begin a spiral of economic decline which continues today.

The mass migration of the New England textile industry following World War I is considered one of the greatest industrial movements in American history. In the short span of 50 years, Rhode Island's share of textile employment dropped from a high of 87,000 workers in 1923 to a low of 12,400 by 1973. This represents a decline from $50.2 \%$ of the State's total manufacturing employment to just over $11 \%$. 6

\footnotetext{
${ }^{5}$ Ibid, p. 43

${ }^{6}$ Rhode Island Development Council, Report of the
} Council, Basic Economic Statistics, (Providence, 1973), p. 84 
Central Falls, with its high concentration of textile manufacturing, was especially hard hit. Between 1935-1955, the city lost over one-half of its textile base, or approximately 2,000 jobs. Perhaps as important to the city's future development was the loss of new investments. As the growth of textiles began to slow following World War I and the industry showed signs of decline, local bankers and business concerns began to curtail investments in new facilities. This trend has continued to the present day and is substantiated by various statistical data.

During the $1970^{\prime} \mathrm{s}$, median family income in Central Falls was the lowest in Rhode Island, growing at approximately one-third of the pace of the median family income of the entire state. 7 In July of $1978,32.2 \%$ of the city's population was receiving some form of transfer payments. 8 New commercial construction from 1968 to 1978 throughout the city was 152,000 square feet, as compared to an average of over 359,000 square feet for other Rhode Island communities with comparable populations. ${ }^{9}$

${ }^{7}$ Rhode Island Department of Employment Security, Report of the Division of Statistics, (Providence, 1979)

${ }^{8}$ Central Falls, Welfare Department, Report of the Department (Central Falls, 1978)

9 Rhode Island Department of Economic Development, Report of the Department, Basic Economic Statistics, (Frovidence, 1980), p. 63 
The number of business establishments along Broad and Dexter Streets has decreased from 220 in 1960 to 148 in 1979. 10 From 1972 to 1979, the vacancy rate has risen from 12 percent to 19 percent. 11

DESCRIPTION OF LOCAL ECONOMY

As alluded to earlier, the local economy is dominated by the manufacturing sector. Approximately 75 percent of the city's labor force is employed in various manufacturing operations. This totals almost 5,000 workers. ${ }^{12}$

Table 1 was taken from a Monograph published by the Department of Economic Development and provides a description of the local economy through employment distribution. 13

${ }^{10}$ The Warren Ccmpany, Market Analysis, Central Falls, Rhode Island, 1980, p. 34

${ }^{11_{\text {Ibid, }} \text { p. } 55}$

12 Rhode Island Department of Economic Development, Report of the Research Division, City of Central Falls, Rhode Island, Monograph, 1976, p. 6

${ }^{13}$ Ibid 


\section{TABLE 1}

\section{Covered Employment and Payrolls in Central Falls} Subject to Employment Security

1 - All Industry

\begin{tabular}{|c|c|c|c|c|c|}
\hline $\begin{array}{l}\text { Code } \\
\text { Number } \\
\end{array}$ & Industry & $\begin{array}{l}\text { lst Qtr. } 76^{\prime} \\
\text { Number of } \\
\text { Firms } \\
\end{array}$ & $\begin{array}{l}1975 \\
\text { Annual } \\
\text { Payroll } \\
\end{array}$ & $\begin{array}{l}\text { March } \\
1976 \\
\text { Number } \\
\text { Employees } \\
\end{array}$ & $\begin{array}{l}\% \text { of } \\
\text { Total } \\
\text { Covered } \\
\text { Employees } \\
\end{array}$ \\
\hline $15-17$ & Construction & 22 & 472,253 & 52 & $0.8 \%$ \\
\hline $19-39$ & All Manufacturing & 70 & $37,277,829$ & 4,944 & 75.0 \\
\hline $40-49$ & Trans. Comm. \& Util. & 10 & 643,439 & 86 & 1.3 \\
\hline $50-59$ & Trade & 128 & $5,541,933$ & 863 & 13.1 \\
\hline $60-69$ & Fin. Ins. \& R.E. & 21 & 766,461 & 74 & 1.1 \\
\hline $70-89$ & Service Industries & 75 & $2,820,568$ & 570 & 8.7 \\
\hline TOTALS & & 326 & $\$ 47,522,483$ & 6,589 & $100.0 \%$ \\
\hline
\end{tabular}

Source: Central Falls, Rhode Island Monograph, Department of Economic Development 
Retail trade is the only other significant employer. This sector is represented primarily by small restaurants and variety stores located along Broad and Dexter Streets. A 1979 Market Analysis classified the retail district in Central Falls as a "neighborhood shopping district", providing basic goods and services to local residents, but not attracting significant trade from outside the city. ${ }^{14}$ MANUFACTURING

Central Falls has approximately seventy (70) firms engaged in the manufacture and processing of raw materials into finished products. ${ }^{15}$ The type of industry in Central Falls is directly related to its historic beginnings. Over 75 percent of the city's firms are involved in the manufacture of textiles, apparel and metals and machinery. These industries are clearly the dominant employers in the city, employing over 2,100 workers. The remaining 25 percent are diversified in the products they manufacture as is evident in Table 2 .

14 The Warren Company, Market Analysis, Central Falls, Rhode Island, 1980, p. 48

${ }^{15}$ Silverson, Donald, Survey of Local Manufacturers, Central Falls, Rhode Island, 1978, p. I 


\section{TABLE 2}

\section{Major Products}

$\begin{array}{lrrrr}\text { Type } & \text { Firms } & \underline{q} & \begin{array}{c}\text { Number of } \\ \text { Employees }\end{array} & \text { q } \\ \text { Food Products } & 8 & 16 & 279 & 8.2 \\ \text { Textiles } & 11 & 22 & 765 & 22.5 \\ \text { Apparel } & 1 & 2 & 750 & 22.0 \\ \text { Metals and Machinery } & 16 & 32 & 607 & 17.9 \\ \text { Jewelry and Silverware } & 4 & 8 & 140 & 4.1 \\ \text { Other: } & 1 & 2 & 31 & 0.9 \\ \quad \text { Photofinishing } & 2 & 4 & 12 & 0.4 \\ \quad \text { Plastics } & 3 & 6 & 30 & 0.1 \\ \quad \text { Woodworking } & 2 & 2 & 14 & 0.4 \\ \quad \text { Chemicals } & 1 & 2 & 650 & 19.1 \\ \quad \text { Glass Products } & 1 & 100 \% & 3.39 & 120 \\ \quad \text { Juvenile Accessories } & - & & 398 & 100.0 \% \\ \text { TOTALS: } & 50 & & \end{array}$

Source: Survey of Local Manufacturers', Central Falls Division of Planning, 1978 
The industrial base is largely made up of small firms employing less tran 50 persons. Eighty (80) percent of the city's manufacturers fit into this category. According to the 1978 Manufacturers' Survey, only 12 percent employ over 100 workers. Analysis of the size of firm by type of manufacturer indicates that forty (40) percent of the "small firms" manufacture fabricated metals and machinery.

Examination of the labor market for industry in Central Falls indicates that one in every three workers is a Central Falls resident. ${ }^{16}$ Seventy-five (75) percent of the employees in the city's industry are from the Blackstone Valley (Central Falls, Cumberland, Lincoln, and Pawtucket). Therefore, the industry in Central Falls relies heavily on local residents for its labor needs. This labor pool offers a distinct locational advantage to industry in Central Falls.

The 1978 Manufacturers' Survey attempted to assess the type of employment offered by local industry. Results indicated that the ratio of skilled to unskilled is $8: 1$. This data is somewhat misleading, however, since the majority of these positions are to operate the equipment in the textiles and fabricated metals industries. While these jobs require six (6) months to a year of training, starting salaries are low ( $\$ 2.65-\$ 4.00 /$ hour -1978$)$.

${ }^{16}$ Silverson, Donald, Survey of Local Manufacturers, Central Falls, Rhode Island, 1978, p. 10 
A description of local industry requires some information on the location of industry and the facilities they occupy. Figure 3.0 shows that industry in Central Falls is located in six (6) manufacturing sites. 17 Combined area for the six sites is 230 acres. Table 3 indicates that sites 1, 4, and 6 are totally occupied. Site 2 has physical characteristics that severely limit the industrial development potential of $64 \%$ and it is comprised of 66 acres. The land is below water level or marshy and within the flood plain of the Blackstone River. Site 3 is mostly taken up by industrial and other uses. The vacant land is fragmented into such small parcels that it can best be used as reserve for expansion by existing plants. Site 5 is partly developed. The remaining vacant area is marshy and site preparation work would be subject to wetlands regulation.

As one would expect, a city of Central Falls' size has very little open space for development. In light of this fact, the age and condition of its industrial building stock is important when considering the potential for industrial growth in Central Falls.

17 Rhode Island Statewide Planning Program, Land Zoned for Industrial Use:, Inventory and Analysis, Technical Paper Number 76, 1978 


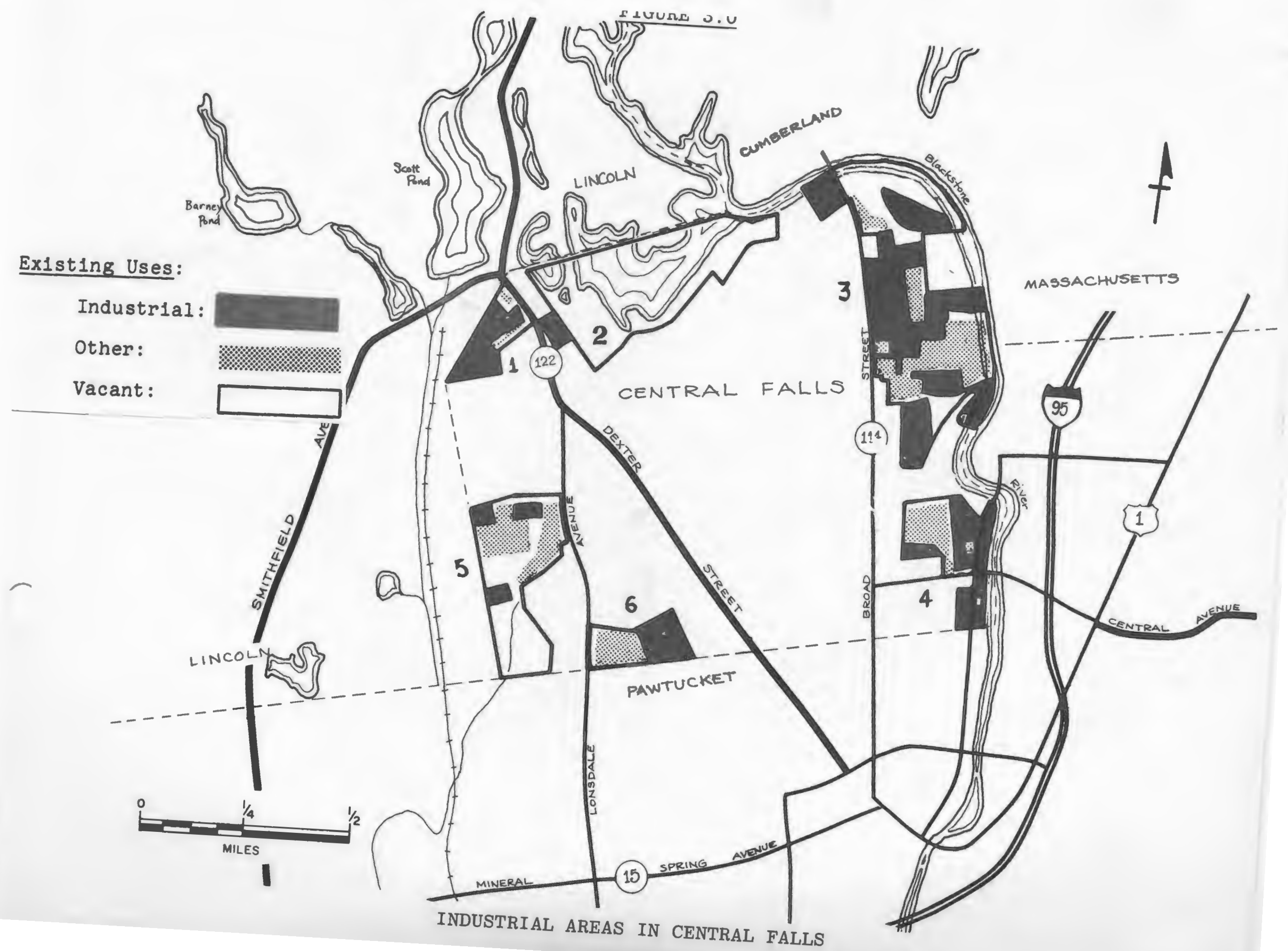


TABLE 3

ANALYSIS OF LAND ZONED FOR INDUSTRY

Central Falls

\begin{tabular}{|c|c|c|c|c|c|c|c|c|c|}
\hline \multirow[b]{2}{*}{$\begin{array}{l}\text { Site } \\
\text { Number }\end{array}$} & \multirow[b]{2}{*}{$\begin{array}{l}\text { Size } \\
\text { (Acres) }\end{array}$} & \multicolumn{4}{|c|}{ Existing Use (Acres) ${ }^{a}$} & \multicolumn{3}{|c|}{ Transportation Facilities ${ }^{c}$} & \multirow[b]{2}{*}{$\begin{array}{c}\text { Railroad Access } \\
\text { (On Site) }\end{array}$} \\
\hline & & 1 & 0 & $\mathrm{~V}$ & $\begin{array}{l}\text { Public } \\
\text { Utilities }\end{array}$ & $\begin{array}{l}\text { Within } \\
\text { l Mile }\end{array}$ & $\begin{array}{l}1-5 \\
\text { Miles }\end{array}$ & $\begin{array}{l}\text { Over } \\
5 \text { Miles }\end{array}$ & \\
\hline 1 & 10 & 8 & 2 & & $E, W, G, S$ & $\mathrm{~S}$ & I & $\mathrm{A}$ & No \\
\hline 2 & 66 & 2 & & 64 & $E, W, G, S$ & $\mathrm{~S}$ & I & A & No \\
\hline 3 & 80 & 47 & 22 & 11 & $\mathrm{E}, \mathrm{S}, \mathrm{W}, \mathrm{G}$ & $\mathrm{S}$ & I & $\mathrm{A}$ & Yes \\
\hline 4 & 22 & 14 & 7 & 1 & $\mathrm{E}, \mathrm{S}, \mathrm{W}, \mathrm{G}$ & $\mathrm{S}, \mathrm{I}$ & & A & Yes \\
\hline 5 & 38 & 4 & 14 & 20 & $E, W, G, S$ & $S, I$ & & A & No \\
\hline 6 & 14 & 9 & 5 & & $E, W, G, S$ & $S, I$ & & $\mathrm{~A}$ & Yes \\
\hline$\overline{6}$ & $\overline{230}$ & $\overline{84}$ & $\overline{50}$ & $\overline{96}$ & & & & & \\
\hline- & - & - & - & - & & & & & \\
\hline
\end{tabular}

\footnotetext{
a. I-Industrial; O-Other; V-Vacant

b. E-Electric; W-Water; S-Sewer; G-Gas

c. S-State Highway; I-Interstate Highway; A-Airport
}

Source: Rhode Island Statewide Planning Program, Technical Paper No. 76 Land Zoned for Industrial Use: Inventory and Analysis, 1978 
A significant portion ( $44 \%$ ) of the city's factories are over fifty (50) years old. Of these, 10\% are over 100 years old; clear reminders of Central Falls industrial past. While many of these structures have been properly renovated and maintained over the years; others present maintenance and operational problems. Despite this fact, surveys performed by the city's Division of Planning have shown that little vacant floor space is available. Much of this space, because of its antiquated design and location in the basement or in the upper stories, is underutilized.

MARKET AREA FOR PRODUCTS

Economic base theory asserts that there are two kinds of industries: One group exports its products and services outside its region; these are returned to the region in the form of money. The money brought into the region by the export (basic) industries contributes to the growth of industries (non-basic) which produce for local consumption. As a region's boundaries are extended, either through actual growth or arbitrary selection, export sales for the original industries tend to decrease and more sales occur within the region.

Of course, any theory has its flaws, and economic base theory is not an exception. Review of the survey results indicates that few industrial establishments produce exclusively for out of region or for local markets. 
Therefore, to place industries in either basic or non-basic categories is an oversimplification which is not supported by actual market behavior.

Some elementary economic base analysis provides an understanding of the distribution of products manufactured in Central Falls. If Rhode Island is defined as the region, with all sales outside the state designated export sales, $60 \%$ of the city's industrial establishments are basic, while just $12 \%$ ( 6 firms) are non-basic.

If the region's boundaries are extended to include all of Southeastern New England, with all sales outside the region considered export sales, $40 \%$ of the city's manufacturers are engaged in basic activities, while $22 \%$ are non-basic and distribute their products within the region. This is in line with economic base theory, which states that export sales tend to decrease as a regions boundaries are extended.

On the average, $48 \%$ of all products manufactured in Central Falls are distributed nationa11y, 23\% are distributed regionally (throughout Southeastern New England), $26 \%$ are manufactured for distribution within Rhode Island and only $3 \%$ of all the products are distributed internationally. If this data is aggregated, $74 \%$ of all products manufactured in the city are marketed outside Rhode Island. As cited above, $60 \%$ of the city's firms do over $90 \%$ of their business outside Rhode Island. 
One can conclude that a significant majority of the city's firms rely on export markets and that a large part of Central Falls industrial base is influenced as much by national economic trends as local economic conditions. Therefore, Central Falls industry brings new money into the Blackstone Valley and contributes to its economic stability and growth. However, because of this dependence on export markets, many firms are not tied to a location in Central Falls. It is significant to note that $46 \%$ of the city's firms have no sales within Rhode Island, and $38 \%$ have no sales in Southeastern New England.

CURRENT TRENDS IN LOCAL INDUSTRY

A 1978 Industrial Survey performed by the Blackstone Valley Chamber of Commerce reported that manufacturing as a percentage of total employment in the Blackstone Valley was decreasing. 18 From 1960 to 1977 , the portion of the work force engaged in industry dropped from 63 percent to 54 percent. In Central Falls, however, this has not been the case. Table 4 shows that the number of manufacturing employees was virtually the same in 1977 as it was in 1958 .

${ }^{18}$ Blackstone Valley Chamber of Commerce, An Inventory of the Status, Needs, and Potential of Industry to the Blackstone Valley, 1978, p. 3 
TABLE 4

Central Falls: Number of Firms, Manufacturing Employment and Payrolis

$\underline{1958-1977}$

\begin{tabular}{lcccr}
$\frac{\text { Year }}{77}$ & Firms & Employment & Central Falls & \multicolumn{1}{c}{ State } \\
76 & 69 & 4793 & $50,352,106$ & $1,333,296,294$ \\
75 & 72 & 5257 & $46,489,702$ & $1,214,923,742$ \\
70 & 69 & 4737 & $37,277,829$ & $1,047,109,517$ \\
67 & 79 & 3822 & $23,983,769$ & $819,792,283$ \\
58 & 82 & 3996 & $19,964,017$ & $771,672,700$
\end{tabular}

Source: Rhode Island Department of Economic Development, Report of the Department, Basic Economic Statistics, 1979, p. 67 
During this time period, the number of firms dropped from 84 to 69 , indicating that larger firms employed a greater portion of the labor force in 1977. The city's industrial base is still comprised of mostly small firms (less than 25 employees) that do under \$1 million of annual sales and a good portion of these rely on unskilled employees. A large portion (45\%) of employees in Central Falls manufacturing sector who work in textile or apparel industries. Both textiles and apparel are declining in the Blackstone Valley and throughout New England, having moved to the South and elsewhere to be closer to markets and supplies and to benefit from more favorable tax policies and non-union labor.

These data raise serious questions concerning the overall economic base in Central Falls. The larger number of persons holding low-paying jobs can contribute little to the city's housing stock, tax base, and retail sector. The large number of smaller firms are generally more susceptible to fluctuations in the economy than larger firms with better developed markets and deeper capital reserves. The lack of growth potential in the city's industrial mix is reflected in Table 5. New construction for manufacturers totaled just 59,000 square feet of floor space for the years 1970 through 1978. 
$-18-$

TABLE 5

New Construction for Manufacturers in Central Falls - 1955-77

1,000's of Square Feet of Floor Space

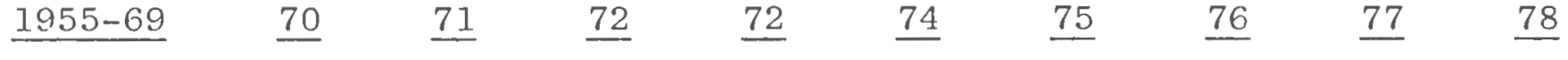

4.17

$-\quad 2$

6

5

$1 \quad 22$

$-\quad 12$

11

Source: Rhode Island Department of Economic Development, Report of the Department, Basic Economic Statistics, 1979, p. 34 
The importance of local industry to Central Falls economy was recognized by the Mayor when he enlisted the city's Division of Planning and Community Development in 1978 to study the needs and concerns of the city's manufacturing community. This symbolized an important first step on the part of municipal government in Central Falls to involve itself in industrial development. The 1978 Manufacturers' Survey emphasized five (5) areas of investigation:

(1) General background information

(2) Satisfaction with existing sites and buildings

(3) Needs and problems

(4) Plans for expansion and relocation

(5) Suggestions for city support

Some of the descriptive data has already been cited to introduce the reader to Central Falls industry. Beyond this, the survey gave local officials some insight into the issues and problems confronting local manufacturers. The survey indicated that $40 \%$ of all firms have expansion plans, either at the present site or at an additional plant. Another $15 \%$ indicated dissatisfaction with their existing site and plan to relocate.

Top priority needs of those firms surveyed were:

-- Improved shipping and receiving facilities

--More floor space

--More efficient heating system and building improvements to reduce energy consumption 
These same firms cited inadequate parking and poor access as major problems.

To address the needs, the manufacturers suggested that the city assist in the identification of available industrial sites and buildings. They also requested assistance in making contact with local, state, and federal funding sources. Further, technical assistance for meeting government regulations was requested.

In summary, Central Falls has a diversified economic base which can be attributed to a large number of small and medium sized manufacturing firms. A high percentage of these firms manufacture products that are distributed nationally and therefore, bring new money into the local economy through employment, capital investment, and taxes. While 50\% of the firms surveyed expressed satisfaction with their present site, a high percentage stated the desire to expand.

Central Falls must address the needs of this segment of the manufacturing community in a variety of ways to retain its industry. Initial outreach efforts have identified a number of areas in which local government can offer its support. While their suggestions are valuable and merit study, the city's industrial development problems require a more comprehensive approach. It is the purpose of this study to provide a clear and consistent strategy for addressing these needs. The development and implementation of this strategy can lead to multiple economic benefits for the community, specifically new employment opportunities and expanded tax revenues. 
CHAPTER II.

PUBLIC INVOLVEMENT IN ECONOMIC DEVELOPMENT 
FEDERAL AND STATE PROGRAMS

In the past few years, economic development has emerged as an important element of governmental policy in dealing with the problems of older urban areas. Economic development refers generally to joint public/private efforts to reshape and increase private investment. ${ }^{1}$ The overall purposes of these efforts are to increase employment and local tax revenues.

Nationally, urban area economic development is rooted in the provisions of the Public Works and Economic Development Act of 1965. The act created the Economic Development Administration in the U. S. Department of Commerce. Since 1969, EDA has offered assistance to cities. Such urban assistance has been steadily increased with progressively larger sums of money provided since 1975.* Other federal agencies' programs - The Small Business Administration, The Department of Housing and Urban Development and the Department of Labor - also have become important to economic development in urban areas.

${ }^{1}$ providence Industrial Development Task Force, Final Summary Report, An Industrial Development Program for Providence, Rhode Island, 1979, p. 13

* As of this writing, The Reagan Administration has proposed to eliminate EDA from the federal budget. They have proposed to include economic development funding with other community development funds in block grants for distribution by the states. 
The purpose of this study is not to describe and analyze the various Federal and State economic development programs, but rather to choose those programs that have direct relevance to the situation in Central Falls. What follows then is not a complete inventory of funding programs available to Central Falls, but a discussion of sources of technical and financial assistance that the city has had experience with or will utilize in strengthening its industrial base.

\section{FIIANCIAL ASSISTANCE}

Central Falls receives its broadest funding support from the Department of Housing and Urban Development's Small Cities Program. Currently, the city is in the last year of a three (3) year, $\$ 2.1$ million program. During the first two years, economic development funding was relatively small $(\$ 75,000)$. Funds were utilized to conduct a survey of Central Falls manufacturers and to organize a comprehensive program to revitalize the Central Business District. The latter program consists of public improvements, grants for storefront renovations and a market analysis.

In the current fiscal year (FY $81^{\prime}$ ), funds were set aside to establish an "economic development fund" for industry. The city will use these funds $(\$ 30,000)$ to provide secondary financing in the form of low interest loans to existing or new industry. These funds will be made available 
directly to the business or indirectly through the SBA sanctioned Ocean State Business Development Authority, a statewide non-profit development corporation that packages financing through SBA's 502 and 503 programs. Thus, by combining monies from two federal sources; HUD and SBA, the city will leverage private investment for industrial development .

Another program sponsored by HUD for economic development projects in older distressed cities is the Urban Development Action Grant Program. Enacted as part of President Carter's Urban Policy in 1977, UDAG provides a special mandate to stimulate private investment in central cities by providing federal funds for projects jointly sponsored by public and private sources. ${ }^{2}$ UDAG's role is to assist private investors by making up the difference between costly urban and less costly suburban development. past government programs for urban revitalization expended federal funds to encourage private investment often long before such investment was forthcoming. UDAG does not engage federal funds for any purpose until both cities and private investors give written evidence of firm private commitments to development.

${ }^{2}$ U.S. Department of Housing and Urban Development, Report of the Department, Action Grants: Revitalizing and Conserving Cities, (Washington, 1980), p. 7 
This new federal approach to economic development is designed to help cities and the private sector achieve their own ends rather than narrow ends dictated by the federal government. The broad federal goal of center city redevelopment is achieved in the process. Such flexibility is needed in dealing with the private sector, but puts the burden on the city to structure a "deal" that will accomplish the community's economic goals and still assure the developer a reasonable profit. This responsibility requires an entrepreneurial approach to problems of local industry, an unfamiliar role to local planners. To capitalize on development opportunities, the city must strengthen its economic development capacity by building support with local manufacturers and in turn rely on their expertise.

Central Falls' ability to package and finance economic development projects was greatly enhanced by the formation of the Ocean State Business Development Authority. Typically, local governments are ill-equipped to create local development corporations to accomplish business development. In a small city like Central Falls, there is insufficient demand, skills, and capital resources to maintain an intensive level of activity. OSBDA will function on a statewide level and provide the following services.

(1) Act as a conduit for a pool of federal grant programs, such as SBA's 502 and 503 loans, EDA's Revolving Loan Fund, OMBE's business development programs, etc. 
(2) Provide technical expertise for business packaging to firms desiring expansion loans.

(3) Provide venture capital for smaller commercial and industrial firms.

(4) Establish a local industrial job development program.

Specifically, the city will work with OSBDA to provide long term, low-interest financing to local industry. This is accomplished through the sale of debentures that are guaranteed by the Federal Government under SBA's 503 program. The proceeds of the sale of the 503 debentures will be offered at below market rates to the private sector for acquisition of real estate, construction and renovation, and the purchase of equipment.

Other federal programs that represent potential tools for economic development include EDA's proposed Development Finance and Revolving Loan Fund Programs, Historic Preservation Grants and Tax Incentives, the proposed Urban Jobs and Enterprise Zone Act, and State CETA's private sector initiatives.

The Development Finance Program would provide financial assistance to firms located in areas designated on the basis of economic distress. Types of activities funded under this program include fixed asset and working capital projects. Types of assistance include loan guarantees, direct loans, interest subsidies and direct grants. W'hile the above are available to private sector applicants, FDA's Revolving Loan Fund (RLF) Program provides a tool to eligible public applicants to fill in financing gaps in the local financial marketplace which may be hindering development. This program provides 
grants for the capitalization of a loan pool to carry out redevelopment programs. Loans can be used in a variety of ways to recycle land and facilities for job creation with the repayment of loans made by the RLF grantor to be placed in a revolving fund. Legislation to fund these proposals is in Congress. * However, EDA currently operates a business development program and a revolving loan fund under the Public Works and Economic Development Act of 1965, as amended. 3

Two mill sites in Central Falls are under consideration for nomination to the National Historic Register. They are the Coats and Clark mill complex on Pine street and the Central Falls Mill Historic District along the Blackstone River at Roosevelt Avenue. Coats and Clark is primarily located in Pawtucket with two sites located in Central Falls. The proposed Central Falls Mill District contains a large concentration of architecturally and historically important industrial structures including the original stone dam constructed in 1863. The advantages of Register status are eligibility for the Grant In-Aid Program and for special tax relief. The Grant Program provides 50 percent matching grants for the restoration or acquisition of properties listed in the National Register. ${ }^{4}$

${ }^{3}$ Bureau of National Affairs, Report of the Bureau, Competing Successfully for Action Grants, (Washington, 1980) p. 17

* The status of the entire Development Finance Program is uncertain, given the Reagan Administration's proposal to eliminate funding for EDA.

${ }^{4}$ Kennedy, Pamela, Central Falls, Rhode Island, Statewide Historical Preservation Report, $\overline{\mathrm{P}}-\overline{\mathrm{CF}}-\overline{1}$, (Providence, R. I. Historical Preservation Commission, 1978), p. 58 
Also, income producing buildings nominated to the Register or located in a National Register historic district are eligible for the tax incentives of accelerated depreciation provided by the Tax Reform Act of 1976. A tax payer may now amortize over a five (5) year period any capital expenditures incurred in rehabilitating a National Register property which produces income or is used in his business or trade. 5

The Historic Preservation Commission is potentially a resource for our economic development program in that it can provide mill properties for the benefit of the community. A 1978 report on Central Falls published by the Historic Preservation Commission cited the industrial buildings of Central Falls as a "potential, but under-used resource". The report further added:

"Because many of the mills seem to be outdated, demolition and replacement are often suggested. However, renovation can be less costly and will also preserve these handsome reminders of Central Falls' industrial past. A program of economic development and a concerted campaign to locate new industrial users for these mills is necessary... a continuation of industrial uses for most mill structures would be doubly beneficial; it would increase the viability of this rich heritage of mill buildings and promote emp loyment. "6

\footnotetext{
${ }^{5}$ Ibid, p. 56

${ }^{6}$ Ibid, p. 53
} 
These conclusions were translated into two recommendations:

(1) Encourage the continued and expanded use of historic mill buildings for industrial purposes, especially those on Roosevelt Avenue. Of particular importance are the Pawtucket Hair Cloth Mill and the Stafford Mill.

(2) In cases where industrial use of a mill building is no longer economically viable, explore the potential of converting mills to commercial and residential uses.

These recommendations will be returned to in later chapters.

Another proposed program that deserves mention is The Urban Jobs and Enterprise Zone Act of 1980. Under the Act, cities and other local governments could obtain approval from EDA for one or more jobs and enterprise zones within their jurisdictions. Once a jobs and enterprise zone is designated by EDA, the tax incentives would include the following. 7

(1) The affected local government would be required to reduce property taxes within any zone by five (5) percent a year for four (4) consecutive years.

(2) Social Security taxes on both employees and employers within a zone would be reduced.

(3) The capital gains tax rate would be cut 50 percent on investments in a zone business which employs at least half its workers with an enterprise zone.

(4) The income tax rate would be cut by 15 percent for enterprises where at least half of the employees are zone residents.

${ }^{7}$ Congressional Record, Vol, 126, No, 196, June 12, 1980 
(5) Greatly accelerated depreciation of business investments within the zone would be allowed to encourage increased investment in jobcreating enterprises.

The reduction on property taxes would provide a direct reduction in the cost of maintaining a business or home within a zone. The reduction in Social Security taxes would lead to job expansion within zones and increase takehome wages. These incentives represent a significant departure from past federal approaches consisting of massive subsidies. The theory here is that federal policies have been aimed at the symptoms of urban decline and have not significantly altered the costs of locating in urban areas. The Kemp-Chafee bill passes on the benefits directly to the business and the employer. With respect to foregone revenues, the rationale is that revenues are not lost on people who are already unemployed nor on buildings that are already abandoned.

The Urban Jobs and Enterprise Zone Program would be difficult for Central Falls to implement, primarily because of the tax cut required. Over the past ten (10) years, the costs of operating local government have risen dramatically. At the same time, the city's tax base has remained static, causing property taxes to increase each year. To reduce property taxes would force Central Falls to do two things:

(1) Cut-back on local services

(2) Rely more heavily on state and federal funding services. 
Both of these alternatives are undesirable for various reasons. The current service level for many of the city's programs is already quite low, especially in the schools. Salaries of local government employees are already below average and fail to keep pace with inflation. Secondly, Federal Funds continue to diminish due to increasing pressure to reduce government spending.

In light of these facts, Kemp-Chafee is not likely to benefit Central Falls. This small city does not have a sufficiently diverse economy, nor is it geographically large enough to allow for property tax cuts in parts of the city. If these tax cuts were subsidized by federal revenues, then this Act could provide attractive incentives to local industry without putting too severe a burden on local government.

A final source of financial assistance to aid in local economic development are CETA programs. Federal employment and training programs share a common objective with urban economic development efforts to increase employment opportunities for city residents. Local efforts to utilize CETA have been restricted to public service employment. However, CETA does offer cities the resources to link manpower training programs with private sector employment opportunities. CETA Title I funds can be used to reimburse private employers for on-the-job training, for classroom training for specific employment opportunities and job development efforts, and for 
vocational education programs to establish special schools for training in new and expanding industries.

Central Falls receives its CETA funding from the Balance of State prime sponsorship which covers the entire state except for Providence. The Job Development and Training Division is part of the state's economic development agency. This CETA program is explicitly designed to meet private sector needs by providing short term training for specific jobs, rather than social services or general occupational training. The Ocean State Training School, established by Rhode Island CETA, uses modern equipment and private industry trainers to teach workers the technical skills needed by industrial firms. Trainees are then placed in private sector positions.

To date, local efforts in employment training have been limited. The resources exist, however, to organize local industry to identify their labor needs. Rhode Island CETA can then provide the expertise, the facilities, and the financial incentives needed to upgrade the skills level of the local labor force. With the Central Falls population in transition due to the influx of Portuguese and Hispanic immigrants, Rhode Island CETA represents an important component to local industrial development. Many of these immigrants have language difficulties and are unskilled, causing them to be at a distinct disadvantage in the job marketplace. 
Therefore, efforts to increase their employability will not only benefit local industry, but will also prevent this segment of the population from becoming a tax burden on the community

\section{TECHNICAL ASSISTANCE}

In addition to the above mentioned financial incentive programs, these are a number of technical assistance resources available to Central Falls. Locally, the Blackstone Valley Chamber of Commerce is available to business and industry in Central Falls. The Chamber has primarily been involved in the development of suburban industrial parks in Lincoln and Cumberland over the past decade. Recently, however, with a shift in federal emphasis, the Chamber has expressed a shift in their policy toward urban economic development. This new focus seems to have been prompted by urban revitalization efforts on the part of local government in Pawtucket and Central Falls. Both communities have initiated programs to spur investment in their respective downtown business districts and in their industrial base. The Chamber has indicated their interest in these efforts by offering financial and technical support. Specifically, the Chamber has established a task force to study the feasibility of recycling mill structures in the Blackstone Valley for industrial use. After looking at several abandoned mill structures in Central Falls and Pawtucket, the task force will select one for possible redevelopment. Preliminary reports have indicated that the return on investment does not justify rehabilitation because 
of the low rental market. ${ }^{*}$ The costs of locating in an old industrial structure must be subsidized. The degree of subsidy will vary according to the individual project. However, the experience of the Chamber in this area would encourage local manufacturers to make needed capital investments in deteriorating plant and equipment.

The State Department of Economic Development also provides technical support. The Department's Research Division publishes "Basic Economic Statistics" annually. This report is a compendium of economic data summarizing business and industrial activity throughout Rhode Island. It is an important source of data for all those concerned with the state's economy, and especially has provided the city's Division of Planning with documentation of local economic trends.

The Department's Division of Business and Industry provides technical support to business and industry and local government throughout Rhode Island. Information on space availability, site location, and financing is provided by the staff of this division. In August of 1980, technical support was provided to the City of Central Falls to follow-up on the 1978 Manufacturers' Survey. Site visits and interviews were conducted to determine the needs of local industry. This information will assist the city in

*For example, renovation of the former Narragansett Braid Mill required rents of $\$ 5.00-\$ 6.00$ per square foot to cover rehabilitation costs. Available mill space is renting for $\$ 1.00-\$ 1.50$ per square foot, including utilities. 
forming an industrial development plan, and will also result in the packaging of expansion projects. It is expected that this survey, together with financial incentives, will leverage private investment and stabilize and expand local employment.

A final and most promising source of technical support is the Ocean State Business Development Authority mentioned above. OSBDA was formed to fill a vacuum in the state's economic development program. Rhode Island's Department of Economic Development is focused on large commercial and industrial businesses. Much of their efforts continue to be directed at attracting out-of-state firms into Rhode Island. Marketing efforts focus on filling suburban industrial parks in the southern part of the state.* The financing mechanisms that are available are designed for larger projects (over $\$ 100,000$ ).

As mentioned previously, OSBDA is a non-profit development corporation targeted at small business expansions. OSBDA acts as a conduit for SBA financing. Also, this organization will play a vital role in Central Falls' industrial development program by providing much needed technical support. OSBDA will determine the financial feasibility of a development project by analyzing financial statements, projections, and cost figures. They will then

*DED representatives has concentrated their efforts on developing Quonset Point and Howard Industrial Park. Both are in suburban locations south of the Providence-Pawtucket metropolitan area. 
work with the applicant to arrange the best financial terms for the project, and will provide the legal services necessary to secure the loan. These services are not provided by the city, and many times are only available to the small entrepreneur at a considerable fee. The fees and the expertise necessary to analyze a project are often obstacles which the small business cannot overcome.

$\underline{\text { SUMMARY }}$

This chapter has attempted to outline the various mechanisms which facilitate public involvement in economic development. Through these mechanisms, Central Falls can actively participate in the growth of the local economy. The extent to which local government can influence industrial development is considerable, if it adopts policies that help business and industry realize their full growth potential. In a recent survey conducted by the United States Chamber of Commerce, the impact of 100 new industrial jobs on a community was measured to be: 8

-- 359 more people

--100 more households

--91 more school children

- $\$ 710,000$ more personal income per year

- \$229,000 more bank deposits

${ }^{8}$ Small Business Administration, Report of The Administration, Loans to Local Development Companies, (Washington, 1976) 
- -3 more retail establishments

--\$331,000 more retail sales per year

--65 more persons employed in non-manufacturing positions.

In addition to the above multiple benefits, government efforts in economic development also serve to strengthen the tax base and in turn reduce the tax burden on the city's residents.

An underlying theme in this chapter is the development of strong partnerships between local and state government and the private sector. This concept forms the basis of national policy to revitalize America's cities:

"Stronger partnerships must be formed among Federal, State, and Local governments, neighborhood and voluntary groups, and the private sector to help revitalize urban areas and promote sound development patterns".

The President's National Urban Policy Report, 1978

In the next chapter, I will begin to incorporate previously discussed public resources into the development of a sound industrial development program. These programs and services, together with the active participation of the private sector, will form the basis for a planned effort to foster growth in local industry. 
CHAPTER I I I .

LOCAL INDUSTRIAL DEVELOPMENT

Purpose and Scope of Program 
In an article appearing in Nation's Cities on economic development strategies, the author makes an effective case for the preservation of older industrial neighborhoods. ${ }^{1}$ Most economic development efforts seem to be aimed at attracting companies from out-of-town, overlooking what the author believes to be important urban assets. While often in various states of deterioration and disrepair, the older industrial neighborhood offers potentially valuable physical resources and opportunities for business and employment that should be used. These areas make significant contributions to the local tax base and the jobs they provide would be difficult if not impossible to replace. These areas represent sizeable public and private investments: buildings, streets, roads, rail lines, and the necessary service systems are in place and, in most cases, completely financed. ${ }^{2}$

This case is strengthened by some research data. According to a Tennessee Economic Development Department Study (1973), most industrial growth occurs in towns of more than 10,000 people which are close to an interstate highway, and are within twenty-five (25) miles of a metropolitan area. 3

${ }^{1}$ Starr, Richard E., "No. 1: Industrial Preservation", Nation's Cities, April 1978, Vol. 16, \#4, p. 7

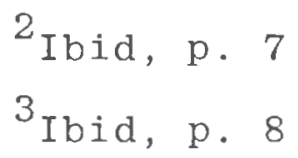


Other research indicates that half of all industrial expansion occurs in existing industries, and much of this involves the expansion of present facilities. ${ }^{4}$

Central Falls certainly fits the description of an "older industrial neighborhood". Its size of one square mile makes it smaller in area than many neighborhoods in larger cities. With approximately seventy (70) manufacturers and seventy-five (75) percent of its labor force engaged in manufacturing, one cannot overemphasize the importance of industry to this community. The lack of vacant land available for assembly significantly reduces the possibilities of recruiting industry from out-of-town. These facts point to the necessity of gearing any industrial development strategy toward the retention of existing industry .

GOALS AND OBJECTIVES

The general goals of the Central Falls Industrial Development Program, as outlined in a position paper prepared by the Division of Planning, are to work toward the expansion of the city's existing industrial base and to encourage the location of new industry in the city, when possible. 
These goals can be translated into the following specific objectives:

(1) To stabilize and increase the local tax base

(2) To provide new job opportunities

(3) To upgrade the skill level of the local labor force

(4) To increase the income level of Central Falls residents

(5) To increase the productivity and profitability of the manufacturing sector

The achievement of these objectives requires publicprivate cooperation along a broad range of policy issues. This means that the problems of industry in Central Falls are complex and their solutions require intervention in many areas, including transportation, finance, education, energy conservation, and intergovernmental relations. Policies must be developed in all these areas to encourage the growth of industry in Central Falls. Due to the density and the predominance of mixed-use development in Central Falls, its neighborhood residential character is a vital force in local planning. The city is not likely to accept any large scale clearance or relocation program. The kind of programs that will be acceptable to the community require a more delicate touch, fitting industry into the existing fabric. This kind of development is likely to be more costly and demands a higher level of public sector involvement and support. 
The following represents an outline of policies developed by the Division of Planning to better coordinate local industrial development. Individually, they represent methods in which industrial development can be encouraged at the departmental level. Together, they represent a positive framework within wich Central Falls can work with the private sector.

\section{Manufacturing}

1. Direct local efforts to attract and support higher paying growth industries such as metals and machinery, electronics, and service-based industries.

2. Enhance the desirability and utilization of the extensive floor space in older mill buildings with public actions (provision of parking, publicizing the existence of available space, subsidizing renovations).

3. Encourage the development of small parcels of vacant land available for public use.

4. Encourage the redevelopment of the Central Falls Historic Mill District.

\section{Transportation}

5. Promote the completion of nearby highway networks such as the Mohassuck Industrial Highway. Oppose the development of new highways through Central Falls, recognizing that a city of only eight hundred (800) acres cannot afford to lose acreage from its tax base.

6. Promote the improvement of city traffic circulation to enhance truck access. Specifically, widen the railroad underpasses which act as barriers to the northeast industrial area.

7. Promote low-cost and efficient mass transit service to metropolitan employment centers (Providence, suburban industrial parks, etc.). 
Employment and Training

8. Develop and promote programs to diversify the skills of the local labor force.

9. Develop and promote meaningful employment and training programs, particularly programs which emphasize onthe-job training; incorporate language instruction in training programs to meet the needs of the non-English speaking residents.

\section{Energy}

10. Encourage and promote the development of alternative energy sources, e.g. solar and hydroelectric power, by industrial users.

11. Encourage and promote energy conservation by industrial users; provide financial and technical assistance to local industry to stimulate investment in conservation measures.

\section{$\underline{\text { Fiscal }}$}

12. Lobby for additional state support to compensate for decreasing revenues from the Rhode Island Manufacturing Equipment and Machinery Tax.

13. Promote alternatives to the property tax structure that will generate additional revenues to meet the increasing costs of municipal services.

14. Utilize federal and state funds to leverage private investment in industrial plant and equipment; utilize the same funds to subsidize new investment in the industrial base.

\section{Organizational}

15. Encourage and promote regional industrial development efforts in the Blackstone Valley.

16. Organize representatives from the financial and business communities to work with local government to formulate an industrial development policy and to identify specific projects.

17. Educate local government officials in the importance of industry to the local economy; identify ways in which municipal services and regulations can better accommodate the needs of the manufacturing sector. 
18. Solicit the assistance of the State Department of Economic Development in promoting older, industrial areas.

ELEMENTS OF THE PROGRAM

To achieve results in each one of these policy areas, a concentrated effort must be undertaken. A partnership must be built between the public and private sectors. Information must be generated and shared. Technical and financial resources must be identified and allocated. Specific programs must be developed and implemented to solve problems which have been identified. These tasks will be part of a comprehensive industrial development program. This program should consist of the following elements: organizational, technical, operational, financial, and promotional.

These elements outline the scope of the Central Falls Industrial Development Strategy. Activities will be organized and programs developed around each element to facilitate the achievement of the aforementioned goals. These elements also establish the order of activities which will lead to the successful implementation of the strategy.

RESEARCH

The first step in any economic development program should be to understand the community's competitive economic position. A strategist must understand the dynamics of the local and regional economy and determine its assets and liabilities. There are several methods in which this under- 
standing can be developed. The first method is to review local economic data such as regional business patterns, census information, Department of Labor publications, and other aggregated sources. The major thrust of this effort is to define the structure of the economy, its major industries, and areas of industrial specialization. This information should also reveal major trends within the local economy. Problems may be anticipated if a major area of specialization is no longer growing. The high percentage of workers employed in the textile industry in Central Falls certainly limits the city's potential for growth as textiles is a declining industry with low-paying jobs. Finally, unemployment and income data should be reviewed in order to identify the dependent populations. This will provide an understanding of the relationship of economic development to social problems.

The second method to obtain a better understanding of the local economy is to talk with the local business community. Such discussions should focus on the strengths and weaknesses of the local economy from their perspective. Business people can often identify major areas that require action.

Also, these discussions not only indicate to the private sector that local government is concerned about their problems, but lay the groundwork for obtaining future cooperation from leaders in the business community. Because of the importance of this research method to the overall development 
program, a full-time staffperson should be assigned this function. In Central Falls, the position of Economic Development Specialist was created to perform a number of functions including; advocacy for the business community, problem-solving, serving as a liaison between the city and the private sector, and planning for industrial and commercial development.

A third method of obtaining information is to perform an economic base study. Studies of this type are expensive to perform and employ a broad range of analytical techniques. Experience suggests that local governments are poorly equipped to utilize the results of such studies, unless they have a sophisticated economic development program in place. The City of Central Falls should use available resources suggested by voluntary assistance from the business and financial communities. Available research funds should be reserved for very specific items which relate to program implementation after the broad outlines of a local economic policy have been framed. Research of this type might include engineering and marketing studies for specific projects. ORGANIZATION

The 1978 Manufacturers' Survey and other outreach efforts have indicated two things: 5

${ }^{5}$ Silverson, Donald, Survey of Local Manufacturers, Central Falls, Rhode Island, 1978 
(1) The manufacturing community has a continued commitment to the local economy.

(2) The needs and problems expressed by local manufacturers require a more aggressive and comprehensive approach by the city.

These findings have prompted Mayor Bessette to appoint a special task force of representatives from the business community to work with local government to develop an economic development policy and identify specific projects that could be undertaken jointly by the city and the private sector. The Task Force will be composed of twelve (12) members and will work with the city's Division of Planning and the Blackstone Valley Chamber of Commerce. The Task Force will undertake investigation in a number of areas, including energy conservation, expansion opportunities, financial mechanisms, municipal services, employment and training needs, education needs of the manufacturing community, and special projects.

Utilizing staff from the Chamber and the Planning Division, the Task Force will utilize the findings of their investigation to set objectives for the city in each of these areas. They will also make recommendations to the city on specific programs to achieve these objectives. This research, coupled with the recommendations, will serve as the foundation for Central Falls' Comprehensive Economic Development Plan for the $80^{\circ} \mathrm{s}$. Some possible elements of 
the plan might include:

--Development of energy audit capability

--Development of a revolving loan fund to help finance capital improvements

-- Improvement of certain municipal services

--Development of job training programs

--Development of a seminar series on selected topics (OSHA regulations, EPA requirements, etc.)

The Task Force will be chaired by Mayor Bessette and membership will be comprised of representatives of major manufacturing groups in Central Falls, the financial community, the Blackstone Valley Chamber of Commerce, and local government. After convening, the Task Force will outline its work plan and establish a time line. The proposed plan calls for the Task Force to divide into committees to research and analyze specific issues and problems. These committees, with staff support from the Division of Planning and the Chamber of Commerce, will report back to the larger group on a monthly basis.

Periodic reports and press releases will be used to document the group's progress. The Task Force will submit its findings to the Mayor in five to six (5 - 6) months. The report should include an analysis of the issues that have been identified and recommendations for programmatic solutions to these problems. The report should also include a list of specific industrial development projects which can be developed further. Finally, the Task Force 
should develop some mechanism whereby representatives of the industrial sector could continue to advise and assist Central Falls in its continued effort to strengthen its economic base.

TECHNICAL SUPPORT

A second critical element of the Central Falls Industrial Development Strategy is the provision of technical assistance to local industry. Surveys of local manufacturers, together with a review of economic data, have identified a number of areas in which technical assistance is needed. This need requires the establishment of formalized mechanisms for information exchange. Through the Task Force, as well as the city's daily contacts with the business community, additional areas needing assistance will be uncovered. However, initial findings indicate that technical assistance is needed in the following categories: energy conservation, financial packaging, space availability, architectural and engineering services, and compliance with government regulations and local ordinances.

Energy conservation is quickly becoming the most critical issue for industry in Central Falls. Energy costs have risen by over fifty (50) percent in the last year, reducing the amount of capital available for inventory, salaries, and re-investment in outdated plants and equipment. Unless innovative methods are developed to reduce energy 
consumption and utilize alternative sources, many firms in Central Falls will face hard decisions in attempting to reduce costs elsewhere. This may mean reducing employment, curtailing needed capital investment, or in the extreme case, relocating to a warmer climate.

The formation of the United States Department of Energy symbolizes the government's mandate to solve the nation's energy problems. Energy conservation programs using government funds have proliferated over the past few years. Conservation measures are not eligible activities under many federal programs, including HUD's CDBG and UDAG programs.

Because of this mandate, and the availability of resources, it is recommended that the city of Central Falis work with local industry to develop innovative methods to reduce energy consumption. By providing technical assistance to manufacturers, the city will indirectly strengthen the economic positions of its industry. Specific areas of assistance should include energy audits and information on conservation technology and hardware.

Emphasis should be placed on providing access to conservation measures that are easy to implement and result in immediate energy savings. Some examples are more efficient heating systems, insulation techniques, and passive solar energy systems. Should efforts be taken to insure that cost effective measures don't create aesthetic disasters, 
mills with windows that have been "cement blocked" could have a very negative effect on Central Falls in a mixed use setting.

A second area requiring technical support is financial packaging. In many of Central Falls' small manufacturing firms, chief executives play multiple roles in the operation of their businesses. Little time is available to search for capital needed for expansion. Often, especially in today's market, it is not a good business decision to rely on commercial banks. High interest rates have fostered the development of a variety of creative financing mechanisms, such as industrial revenue bonds, interest subsidies, loan guarantees, lease guarantees, and grants. Assistance in identifying and in packaging applications for financing from public or private sources is an important tool in helping existing businesses stay in the community and expand.

Parts of the strategy described earlier outlined in greater detail the specific financing options which are available to assist existing businesses. The Central Falls Industrial Development Program should have, as a major component, an inventory of such assistance and competent staff to explain the programs to business people. The city should also be prepared to offer actual application and packaging assistance to businesses seeking to use financing aids. 
The prospect of red tape and complicated forms can discourage a business from applying.

Packaging financial assistance for area businesses requires a substantial investment in personnel. Staff will have to become familiar with different programs, and develop the capacity to evaluate financial deals with an unprejudiced and trained eye. ${ }^{6}$ Staff may have to analyze the firm's own financial position in order to begin filing an application. Success in helping existing businesses obtain the financial assistance they need requires a broad range of talents. Presently, the city's staff commitment of helping the business community consists of one full-time person.

The city is fortunate to have formed an alliance with the Ocean State Business Development Authority. Their services include packaging financial assistance. In addition, a committee of area bankers was formed in the past to analyze the financial statements of applicants to a revolving loan program. These three sources of assistance (city, OSBDA, bankers) could be combined to offer a complete range of technical assistance in financial packaging. A third area for technical support is the provision of

${ }^{6}$ U.S. Department of Housing and Urban Development, Report of the Department, Local Economic Development Tools and Techniques, A Guidebook for Local Government, (Washington, 1979), p. 74 
an inventory of available industrial sites. An up-to-date inventory of available sites, both publicly and privately held, can be a very important tool in helping businesses to locate or remain in the community. 7 The maintenance of such an inventory can be used to match the needs of expanding businesses with available sites, and keeping track of sites which are not readily marketable. These can be targeted for greater attention as part of the overall industrial development effort. Sources of information on available sites include the Division of Planning and Tax Assessor's Office for publicly held sites, private real estate brokers who cater to commercial and industrial clients, and regular surveys carried out by city personnel. At this time, the Division of Planning and Community Development maintains an inventory of vacant industrial sites and serves as an agent in bringing together owners and potential tenants.

Another potential area needing support is architectural and engineering services. Many of the small firms in Central Falls lack the technical capacity to plan their expansion. Such a move often requires technical information such as site analysis, architectural drawings, and cost estimates. The city, through its Division of Planning can offer some of these services to a business to facilitate expansion, or to modernize an existing plant. These include

\footnotetext{
7 Ibid
} 
architectural assistance and cost estimating.

Finally, Central Falls manufacturers have reported that they require assistance in interpreting and complying with federal and state regulations, specifically, air and water pollution regulations, solid waste disposal requirements, and OSHA regulations. ${ }^{8}$ By conducting seminars and issuing position papers, the city could provide a needed service to these businesses, and further indicate that it cares about their problems.

OPERATIONAL

A third critical element of this strategy is the actual operational mechanisms developed for implementation. The term "operational" can be defined to mean any formalized effort of the public and private sectors related to the achievement of the pre-defined goals and objectives of the development strategy. These elements can be of varying scope and degree, ranging from a one-day seminar on environmental codes to a formalized program to perform energy audits on industrial buildings in the city. While it is not within the scope of this paper to develop detailed programs or cost estimates for the various operational elements, it is appropriate to identify some of the factors which must be considered in the implementation of the various strategic elements. This will be done in the context of identifying

${ }^{8}$ Silverson, Donald, Survey of Local Manufacturers, Central Falls, Rhode Island, 1978 
various elements of the strategy which require a concentrated effort to achieve results.

Preliminary discussions have led to the identification of several areas which present opportunities to positively influence the city's industrial climate. Some of these have already been mentioned in the course of outlining this strategy and include energy conservation, employment and training, business counseling, financial packaging, space availability, and special industrial development projects. While the city, through its Planning Division, cannot take on the sole responsibility for implementation in each one of these areas, it can act to coordinate public and private resources.

Leaders in local industry have indicated that they are aware that many of the factors influencing energy costs and supply are beyond local control. The role of local government is to assist industrial users in conservation efforts. Initially, this should take the form of an educational campaign, elements of which might include cost savings, amortization and payback information, tax benefits, and available technical and financial assistance.

A locational advantage for industry in Central Falls is the local labor force. Within a small area, there is a high percentage of skilled and semi-skilled workers. In Central Falis, and parts of Cumberland and Pawtucket, however, the demographics of the communities are changing. Within 
the last ten (10) years, immigrants from Fortugal and Latin America have come to the Blackstone Valley. These people often have language difficulties and lack the skills to successfully compete for a job. The state of Rhode Island conducts job training programs through its Division of Job Development and Training. Locally, the school department provides training by sending a small amount of students to Davies Vocational School. As the social fabric of the community continues to change, training efforts should be intensified to match the needs of local industry. The city can help to accomplish this in two (2) ways first, by organizing a more intensive outreach effort by the State's Manpower Training programs toward addressing the labor needs of local industry. This could be initiated through a series of meetings bringing together state officials and manufacturers with training needs. Secondly, the City of Central Falls can encourage an increased emphasis on vocational training in the school system. The Central Falls school system has one of the highest drop-out rates in the State of Rhode Island. 9 While social and economic factors contribute to this problem, the relevance of the curriculum must be examined. Changes geared to providing more practical education, coupled with opportunities for

$9_{\text {Rhode Island Department of Education (unpublished }}$ data), 1980 
hands-on experience in local industry, may represent a partial solution to this problem. A relationship already exists between the school department and the local CETA office. However, the effort could be strengthened through direct involvement with the city's Industrial Development Program.

As was mentioned above, other operational components of the Industrial Development strategy are loan packaging, the inventory of available industrial sites, and a special Projects Committee. The city should continue to develop its capability to package financing for development. In today's tight money market, the need for creative financing mechanisms is greater than ever. Bond financing, subordinated loans, grants, and tax deferrments can be used to make a particular project financially feasible. The Division of Planning, through its Economic Development Specialist, should continue to work with the financial community and public agencies to assess financing mechanisms. By building up its revolving loan fund, the city will be able to participate in the financing of projects.

The maintenance of a "space bank" of available industrial sites is an important component in that it provides information on potential development opportunities. As mentioned in previous chapters, Central Falls is without large amounts of land available for economic development. 
Vacant parcels are scattered throughout the city. However, these parcels, together with vacant and underutilized buildings, represent a resource that cannot be overlooked. Figures 3-1 and 3-2, display the number of sites that could be developed. Information on these parcels, such as location, size, lease or sale price, and owner will enable the city to match parcels with new or expanding industry. This service is critical in retaining the city's manufacturing base and in attracting new firms to Central Falls. To expand the city's ability to turn limited development opportunities into jobs and tax revenues, it has been recommended that Mayor Bessette and the Special Task Force establish a Special Projects Committee. This committee will identify development opportunities, analyze their potential, and make recommendations for marketing and promotional efforts. The function of this committee will be outlined in more detail in the next chapter.

\section{FINANCIAL}

Public subsidy of private economic development raises several policy issues. Do taxes make a difference? Will financial incentives attract firms that otherwise would not locate in a particular area? How important is financial assistance as opposed to physical help with plant start-up

${ }^{10}$ Central Falls Division of Planning and Community Development, 1975 


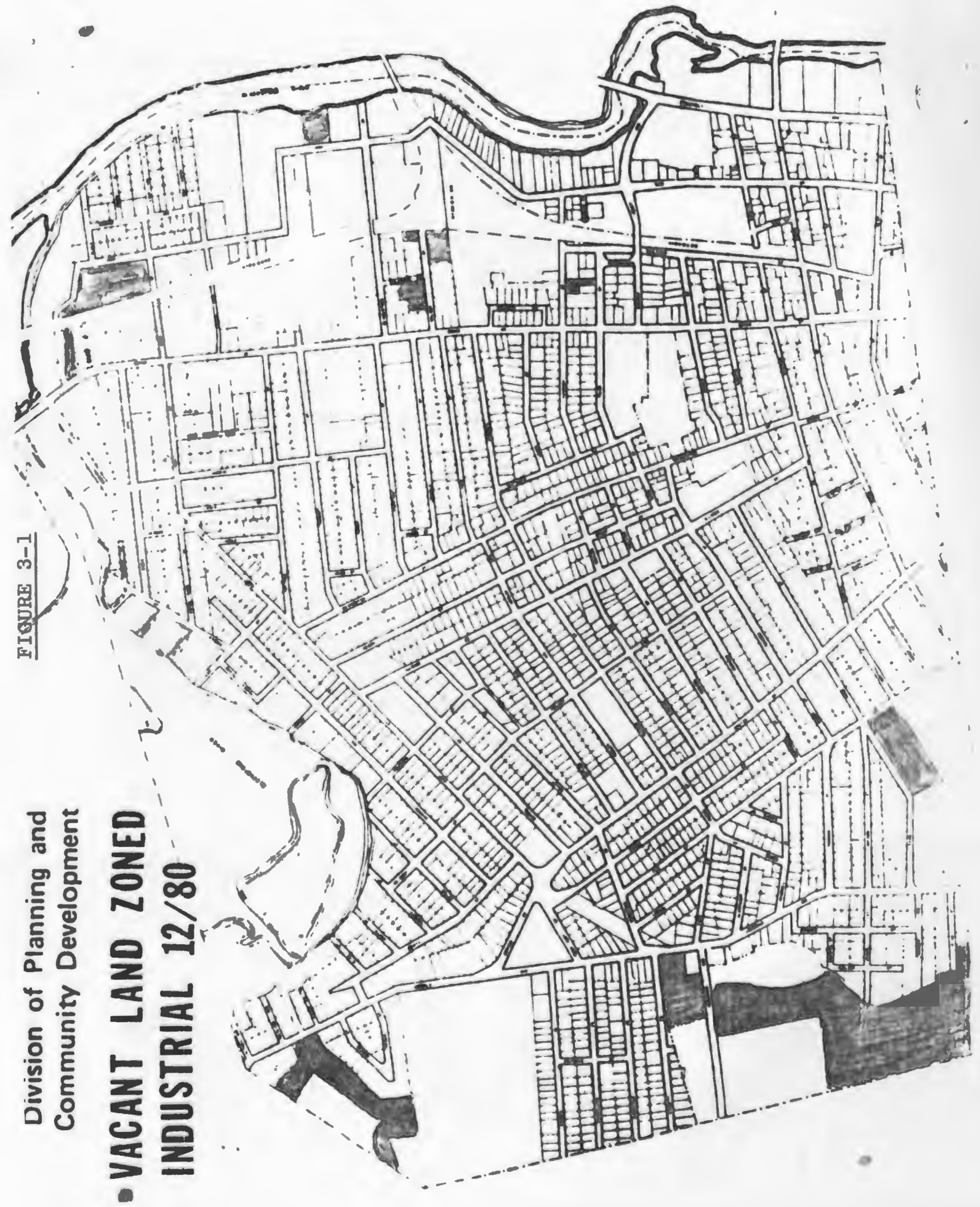




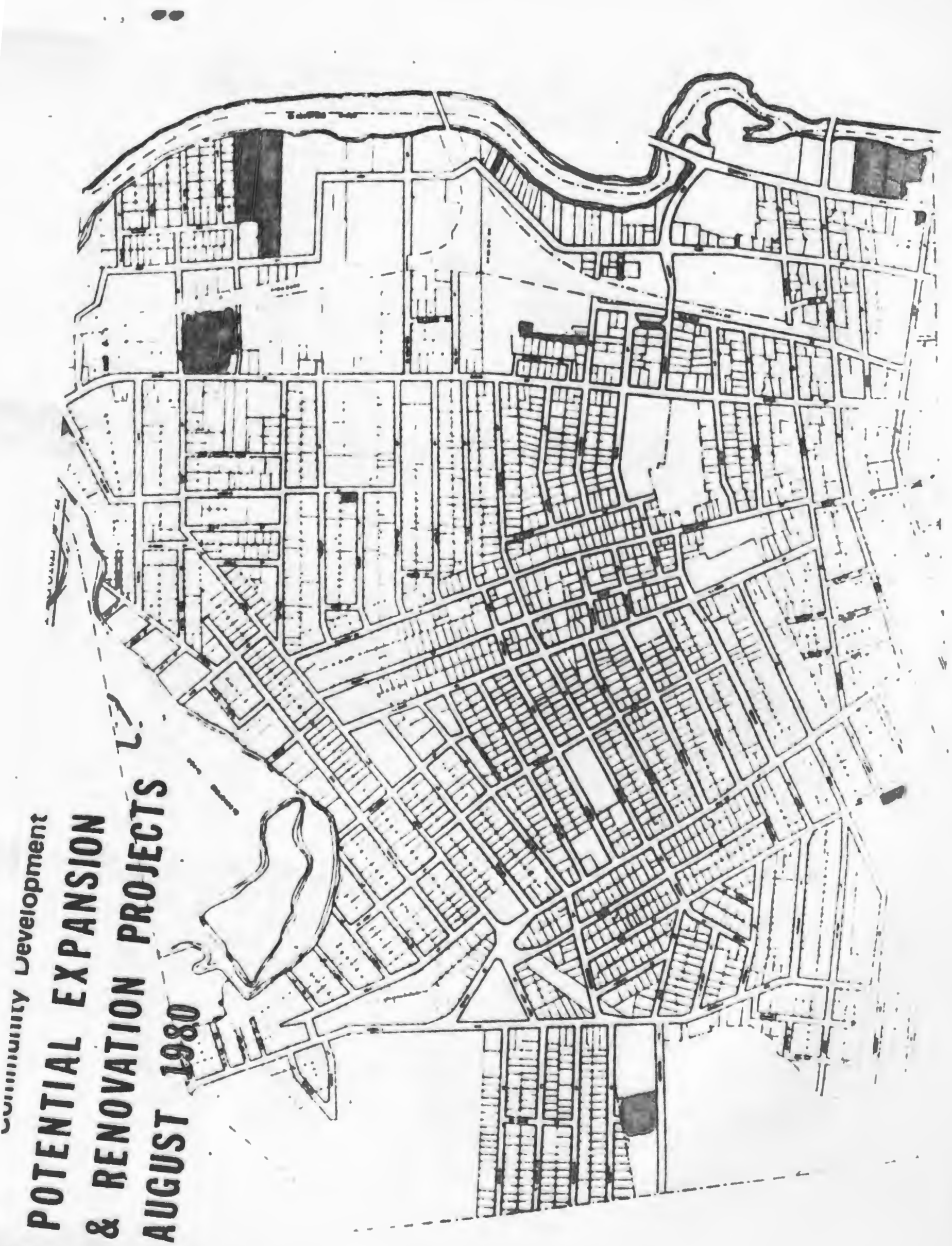


(new roads, sewerage lines, water mains, environmental permits, labor training)?

If effective, fiscal incentives can increase the tax base, create new jobs, reduce unemployment compensation and welfare costs, and improve the local economic climate. However, it has been found that non-fiscal factors (raw materials, markets, labor, energy, construction costs) nearly always dominate business location decisions. Studies indicate that little correlation exists between fiscal incentives and business location decisions, except possibly in selecting the precise location within an already chosen metropolitan area. ${ }^{11}$

The decision process of a manufacturer seeking a new plan involves, first identifying those regions that offer economical access to raw materials, markets, labor, and energy. These production and marketing costs, along with taxes, usually make up most of the total cost. Regional differences in construction, energy, and labor costs are generally too large to be outweighed by any potential tax and fiscal differences (See Tables 6, 7, and 8). For example, a comparison of business taxes and non-agricultural wages per $\$ 100$ of corporation profits in each of the 50 states

${ }^{11}$ Cornia, Gary C., Testa, William A., stocker, Frederick D., State-Local Fiscal Incentives and Economic Development, Academy of Contemporary problems, (Columbus, 1978), p. iii 
reveals that variations in business taxes among states are far less than the wide range in wages paid per $\$ 100$ of profits (Table 6). State tax differences per $\$ 100$ of profit have a range of around $\$ 25$, while wage differences per $\$ 100$ of profit exceed $\$ 250.12$ A considerable tax disparity would be required to offset such dissimilar wage rates.

For construction costs, interregional variations are substantial and can easily influence a location decision. The F. W. Dodge index of construction costs reveals a significant difference in building costs among the seventynine (79) largest SMSA's (Table 7). For example, it costs approximately thirty (30) percent more to build in New York City than it would to build a similar structure in Charlotte, North Carolina. ${ }^{13}$ Thirdly, regional differences in energy costs are considerable and represent a significant factor in commercial and industrial development. In 1975, the cost of electric power varied among regions by a factor of more than $2: 1 \quad(\text { Table } 8)^{14}$.

Once having decided on a particular region of the country, the manufacturer must then select the state or area that offers the greatest potential profit. At this stage, many of the cost cifferences that were significant

$$
\begin{aligned}
& 12 \text { Ibid, p. } 7 \\
& 13 \text { Ibid, p. } 8 \\
& { }^{14} \text { Ibid, p. } 12
\end{aligned}
$$


TABLE 6

WAGES AND TAXES PER \$100 OF BUSINESS PROFIT, BY STATE

New England Region

Maine

New Hampshire

Vermont

Massachusetts

Rhode Island

Connecticut

Middle Atlantic Region

New York

New Jersey

Pennsylvania

East North Central Region

Ohio

Indiana

Illinois

Michigan

Wisconsin
Taxes Paid Per $\$ 100$ of Profits

$\$ 21.00$

15.00

20.00

23.00

23.00

27.00

33.00

25.00

23.00

21.00

18.00

23.00

31.00

24.00
Non-agriculture Wages Per $\$ 100$ of Profits

$\$ 317.00$

324.00

339.00

382.00

324.00

396.00

385.00

396.00

388.00

481.00

457.00

445.00

557.00

440.00 
West North Central Region

Minnesota

Iowa

Missouri

North Dakota

South Dakota

Nebraska

Kansas

South Atlantic Region

Delaware

Maryland

Virginia

West Virginia

North Carolina

South Carolina

Georgia

Florida
Taxes paid per

$\$ 100$ of Profits

$\$ 28.00$

14.00

16.00

19.00

16.00

12.00

19.00

23.00

21.00

18.00

26.00

17.00

18.00

16.00

19.00
Non-agriculture Wages Per $\$ 100$ of Profits

$\$ 431.00$

400.00

382.00

323.00

338.00

347.00

353.00

461.00

336.00

334.00

400.00

304.00

317.00

326.00

342.00 
East South Central

Kentucky

Tennessee

Alabama

Mississippi

West South Central

Arkansas

Lousiana

Ok I a homa

Texas

Mountain Region

Montana
Idaho
Wyoming
Colorado
New Mexico
Arizona
Utah
Nevada

Taxes Paid Per $\$ 100$ of Profits

$\$ 14.00$

15.00

15.00

20.00

14.00

38.00

20.00

23.00

28.00

20.00

32.00

21.00

27.00

24.00

22.00

27.00
Non-agriculture Wages Per $\$ 100$ of Profits

$\$ 366.00$

323.00

350.00

284.00

299.00

442.00

343.00

357.00

405.00

344.00

N.A.

405.00

308.00

394.00

405.00

464.00 


\section{Pacific Region}

Washington

Oregon

California

Alaska

Hawaii
Taxes Paid Per

$\$ 100$ of Profits

$\$ 26.00$

19.00

32.00

19.00

20.00
Non-agriculture Wages Per $\$ 100$ of Profits

$\$ 416.00$

385.00

409.00

490.00

375.00

Source: Tax data from Business Taxes in Ohio: A Study of the Level of Business Taxation in Ohio Compared to Other States, Ohio Department of Taxation, August, 1974

N.A. Not Available 
$-65-$

TABLE 7

INDEX OF CONSTRUCTION COSTS FOR MAJOR SMSAS $(1.00=$ Average $)$

Index of

Labor Costs

Index of

Materials Costs

New England Region

Boston, Massachusetts

1.02

.98

Bridgeport, Connecticut

.94

1.00

Hartford, Connecticut

.95

1.00

Manchester, New Hampshire

.82

Portland, Maine

.77

1.00

Providence, Rhode Island

.90

.97

Springfield, Massachusetts

.92

1.25

Middle Atlantic Region

Albany, New York

.97

1.19

Buffalo, New York

1.08

.95

Camden, New Jersey

1.04

.99

Harrisburg, Pennsylvania

Nassau Suffolk, New York

.88

.89

1.16

.89

Newark, New Jersey

1.03

1.00

New York City, New York

1. 19

1.01

Philadelphia, Pennsylvania

1.04

1.01

.98 
$-66-$

Index of

Labor Costs

Pittsburgh, Pennsylvania

Rochester, New York

Syracuse, New York

Trenton, New Jersey

East North Central Region

Chicago, Illinois

Cincinnati, Ohio

Cleveland, Ohio

Columbus, Ohio

Detroit, Michigan

Evansville, Indiana

Indianapolis, Indiana

Lansing Michigan

Madison, Wisconsin

Milwaukee, Wisconsin

Minneapolis, Minnesota

Springfield, Illinois

West North Central Region

Bismarck, North Dakota

Des Moines, Iowa

Kansas City, Kansas
1.08

1.02

1.02

.89

1.03

1.03

1.12

.96

1.15

.93

.95

.95

.91

1.01

.95

.93

.78

.84

1.00
Index of Materials Costs
1.04
1. 04
.95
1.00

1.01

1.01

1.08

.93

1. 14

.94

1.00

.95

.90

1.05

1. 14

.94

1.10

.98

.98 


\section{Index of \\ Labor Costs}

Omaha, Nebraska

St. Louis, Missouri

Sioux Falls, South Dakota

Topeka, Kansas

Wichita, Kansas

South Atlantic Region

Atlanta, Georgia

Baltimore, Maryland

Charleston, West Virginia

Charlotte, North Carolina

Jacksonville, Florida

Miami, Florida

Norfolk, Virginia

Richmond, Virginia

Savannah, Georgia

Tampa, Florida

Wilmington, Delaware

East South Central Region

Birmingham, Alabama

Chattanooga, Tennessee

Jackson, Mississippi
.91

.97

.70

.84

.88

.81

.92

.92

.50

.78

.91

.74

.67

.76

1.06

1.00

.76

.75

.71
Index of

Materials Costs

1.05

.97

1.01

.95

.95

.91

.98

1.05

.91

.95

.82

.97

1.06

1.07

.83

1.01

.94

1.02

.92 
Index of

Labor Costs

Louisville, Kentucky

Mobile, Alabama

Nashville, Tennessee

West South Central Region

Austin, Texas

Dallas, Texas

El Paso, Texas

Houston, Texas

Little Rock, Arkansas

Oklahoma City, Oklahoma

Shreveport, Louisiana

Mountain Region

Albuquerque, New Mexico

Boise, Idaho

Cheyenne, Wyoming

Denver, Colorado

Las Vegas, Nevada

Phoenix, Arizona

Salt Lake City, Utah
.86

.79

.75

.72

.76

.69

.88

.73

.80

.76

.81

.87

.89

.92

1. 16

.92

.95
.91

1.03

.98

.89

1.07

Index of

Materiais Costs

1.01

.92

.84

.80

.90

.91

1.08

.92

.96

1.01

1.07

.86 
$-69-$

\begin{tabular}{ll} 
Index of & Index of \\
Labor Costs & Materials Costs \\
\hline
\end{tabular}

\section{Pacific Region}

Anchorage, Alaska

1.37

1.43

Honolulu, Hawaii

.85

1.35

Los Angeles, California

1.17

1.01

Portland, Oregon

San Diego, California

1.05

.99

1.10

.96

San Francisco, California

1.20

.99

Seattle, Washington

1.03

.99

Spokane, Washington

.99

.99

Source: Dodge Manual for Building Construction Pricing and Scheduling, (New York: McGraw Hill Information Systems Company, 1977) 
$-70-$

TABLE $\varepsilon$

$\frac{\text { AVERAGE COST OF ELECTRIC POWER, BY REGIONS }}{1975 \text { (Dollars per } 100 \mathrm{KWH} \text { ) }}$

Demand KW

New England

Middle Atlantic

East North Central

West North Central

South Atlantic

East South Central

West South Central

Mountain

Pacific

\begin{tabular}{|c|c|}
\hline 300 & 1,000 \\
\hline$\$ 3.38$ & $\$ 3.22$ \\
\hline 3.35 & 3.18 \\
\hline 2.65 & 2.48 \\
\hline 2.40 & 2.21 \\
\hline 3.03 & 2.77 \\
\hline 2.34 & 2.09 \\
\hline 2.72 & 1.81 \\
\hline 1.91 & 1.75 \\
\hline 1.68 & 1.55 \\
\hline
\end{tabular}

10,000
$\$ 2.95$
2.75
1.96
1.82
2.37
1.74
1.52
1.50
1.30

50,0000

$\$ 2.91$

2.66

1.86

1.76

2.31

1.72

1.47

1.52

1.28

Source: Revitalizing the Northeastern Economy, A Survey for Action, The Academy for Contemporary Problems, 1977, p. 189 
among regions, are no longer important. Construction and energy costs are likely to be similar within a region. At this stage, fiscal incentives are more likely to be influential, though non-fiscal considerations (public services, utility hook-ups, access to highways and railroads, and site availability) are still likely to predominate. ${ }^{15}$

In summary, many important costs influence location decisions. These costs are generally too large to be neutralized by tax and fiscal concessions, except in the final stage. Then the decision on a specific site within a metropolitan area may be affected by fiscal differentials. This conclusion is supported by data on the relative frequency with which various forms of public assistance are used (Table 9).

Schmenner concluded from his research that it is surprising how little public programs are used, even by supposedly knowledgeable Fortune 500 companies. ${ }^{16}$ Although seventy-one (71) percent of new plants received some sort of assistance, companies are very selective in the programs they use and typically do not exploit all government assistance available. Almost as surprising, for plant openings, physical help with plant start-up is valued more than are

15 Schmenner, Roger W., "Location Decisions of Large Firms, Implications for Public Policy," Commentary (a publication of CUED), Vol. 5, No. 1, (Washington, 1981), p. 6 ${ }^{16}$ Ibid, p. 6 
TABLE 9

PUBLIC ASSISTANCE USED BY NEW PLANTS

Types of Assistance

Physical Aid:

Roads, sewerage, water mains, etc.

Labor Training

Assistance with environmental permits

Zoning Changes

Expansion of sewage treatment

Traffic, parking adjustments

Used at Least One (1) Physical Aid

Financial Aid:

Industrial revenue bonds

Industrial revenue bonds for pollution control

Tax abatements or other tax concessions

Used at Least One (1) Financial Aid

Used at Least one (1) Financial/ Physical Aid
Percent of New Plants Using Assistance Plant Openings Relocating Plants

Source: Schmenner, Roger W., "Location Decisions of Large Firms, Implications for Public Policy", Commentary (Publication of CUED), Vol. 5, No. 1, January 1981, p. 6 
much heralded financial considerations. A state or town's provision of new roads, sewerage and water lines, labor training, and assistance with environmental permits are called on considerably more than industrial revenue bonds and tax concessions.

These findings suggest some recommendations for industrial development in Central Falls. Since tax incentives are unlikely to make much difference, their use as a carrot for economic development as well as adapting new financing arrangements as the focus of the development strategy should be avoided. As indicated earlier, the city has not predicated its industrial development strategy solely on financial incentives. A small portion of its CDBG funds, however, have been set aside for companion financing with SBA's 503 program. This has proved to be a prudent move, given the recent developments in Washington. Even before last November's election, it was clear that federal categorical programs aimed at job creation would be closely scrutinized. Congress and the Carter Administration had made dramatic cuts in funding for public service employment programs and had rejected another round of funding for local public works as too expensive. They had also cut funding for direct loan programs in favor of business loan guarantee programs that require federal outlays only as defaults occur. Finally, the Carter Administration had sought to eliminate a number of economic development programs as duplicative of programs in other agencies. 
The SBA 503 program allows "qualified" state and local development companies to issue debentures that carry a one-hundred (100) percent SBA guarantee, to sell those debentures using SBA as their sales agent, and to use the proceeds to make low-interest, subordinated, long-term loans to small businesses. 17 This program should appeal to both Democrats and Republicans in the 1980's because of a number of features, most notably, a funding mechanism that does not contribute to budget deficits, a delivery system that transfers administrative functions from federal employees to development company staff, an eligibility system that directs assistance to small businesses, and a program design that ensures low loss rates and high leverage rates.

By making $\$ 30,000$ in CDBG funds available to the Ocean State Business Development Authority in the form of seed capital, Central Falls expanded its capability to provide financial incentives to local industry without being dependent on federal grant programs. This will enable the city to leverage a small amount of CDBG funds $(\$ 30,000 /$ year) into hundreds of thousands of dollars of private investment. Further, participation in this program removes the administrative burden from the city.

${ }^{17}$ Ewing, Reid, "A Development Program for the 80 's, SBA's New Development Company Program", Commentary (a publication of CUED), Vol. 5, No. 1, (Washington, 1981), p. 20 
$\underline{\text { PROMOTION }}$

Central Falls suffers from an image problem. Its rich cultural heritage and proud tradition have given way to economic and social decline. These problems have been described and analyzed in Chapter one. In the past few years, community leaders have become more sensitive to Central Falls' image throughout the state. Efforts to revive its housing stock and commercial district have been successful. "Pride and friendliness" have become themes for community renewal.

The underlying impact of various community revitalization efforts is that community leaders have begun to take a more active role in Central Falls' future. This effort must extend into its economic development program. For Central Falls to sell itself, it must know what its assets are, be conscious of its liabilities, and know how to present itself positively to business and industry.

It is recommended that the city together with its Task Force, begin a formal promotional effort. Initial discussions with major manufacturers have indicated their general satisfaction with Central Falls. These perceptions can form the basis for promotional materials that provide extensive information to business prospects. A number of information categories should be considered in putting together this package. 
These categories should include government, local services, population characteristics, housing, medical and religious facilities, cultural and recreational facilities, news media, local industries, utilities, financial services, education, labor, and transportation. Information on these categories should not be restricted to Central Falls, but should be extended to the state and the region, when necessary. (For a more extensive outline, refer to the Appendix) .

Figure 3-3 summarizes the various elements of Central Falls Industrial Development Program.

\section{FIGURE $3-3$}

I. Research

Survey of Local Manufacturers

Needs and problems

Expansion plans

Available sites

II . Organization

Special Task Force for Industrial Development

Membership: Manufacturers, bankers, Chamber of Commerce, state and local government

Areas of Investigation: Energy conservation, municipal services, special projects, marketing and promotion

III. Finance

Economic Development Fund

CDBG funds for companion financing with SBA 503 program for acquisition and development of land, buildings, and purchase of equipment and machinery.

Source: Central Falls Division of Planning, 1981 
CHAPTER IV.

OPPORTUNITIES FOR INDUSTRIAL DEVELOPMENT 
A primary goal throughout the formulation of this strategy has been the expansion of Central Falls' industrial base. Through the proposed strategies, Central Falls will be able to retain existing firms and attract new firms with growth potential. To accomplish these ends, public-private programs should be established to deal with a variety of issues - expansion room, access, facilities and utilities, financial assistance, employee training, energy conservation, vacant structures, and organizing existing firms. From these programs, high priority projects can be selected. Some of these will be public improvements such as streetwork, utilities, and promotional programs. Others will require private investment. In this chapter, I will consider the latter, for private investment must follow any public economic development effort if the city's goals are to be met. To assist the private sector in development projects, the city's economic development officials must understand the development process. By being familiar with its many stages, economic planners can identify ways they can be of assistance, reduce the development costs, and, therefore, increase a project's feasibility. Given reductions in federal funds for the economic development, city officials can also use this knowledge for the more prudent allocation of public funds. 
The city must continually work to leverage its limited resources to create employment and tax revenues. This point will be addressed further in the discussion of project evaluation.

The development process has eight (8) identifiable steps: ${ }^{1}$

(1) Market Analysis

(2) Project Identification

(3) Site Acquisition

(4) Negotiation

(5) Planning, Design, Engineering

(6) Financing

(7) Construction

(8) Marketing

While volumes have been written about industrial development, the intent here is to briefly describe each stage of the process, especially those elements that are within the realm of influence of local government.

MARKET ANALYSIS

Before any firm makes a decision to locate a new plant or increase its existing investment, it will examine a number of locational factors. Broadly, these can be defined as energy, transportation, raw materials, labor supply, and the market. In the United states, as technology has progressed, sources of energy have become more

${ }^{1}$ U.S. Department of Housing and Urban Development, Report of the Department, The Private Economic Development Process - A Guidebook for Local Development, (Washington, I979), p. 23 
interchangeable and transportation more efficient. ${ }^{2}$

Improvements in transportation have lessened the cost of distance and industry is becoming more dependent on relatively mobile materials drawn from other manufacturing industries. The bulky and highly localized materials, so important in earlier stages of industrialization, no longer exert the same pull on plant location. The decrease in the importance of transportation and raw materials has been accompanied by an increase in the significance of the labor supply and the market. 3 The growing importance of the market as a factor in industrial location is associated with the desire of the large scale manufacturer of both consumer goods and industrial components to be near a major concentration of consumers. Some of the external economies usually found in major industrial agglomerations are becoming more mobile geographically. ${ }^{4}$

${ }^{2}$ Fernstrom, John, Bringing in the Sheaves - Effective Community Industrial Development Programs, U.S. Department of Agriculture, (Washington, 1974), p. 65 This has been the case at least until the oil supply increases of the early 1970's began to have an impact.

${ }^{3}$ Ibid, p. 66

${ }^{4}$ Ibid 
This is not just in labor supply or transportation, but also in services. Information can now be transmitted very efficiently over long distances with advances in telecommunications and computer technology. A small town, i.e. Central Falls, can now offer many of the services that a firm could expect to find in a large central business district (CBD). Much of this rationale was taken from Fernstrom's manual on "Effective Community Industrial Development Programs". He concludes that the increasing flexibility of many of the location factors is widening the location choices in many industries. Therefore, increasing the possibility of location decisions being made on grounds other than those that have directed or guided industry improves the likelihood that a community development group that is sensitive to the business perspective will have more opportunities in the future. In Central Falls, the cultivation of this sensitivity to business is presently underway. (See Chapter III - Organization)

Market information on Central Falls' industry reveals that $48 \%$ of all products manufactured in Central Falls are distributed nationally, 23\% are distributed throughout Southeastern New England, and 26\% are manufactured for distribution within Rhode Island. Further aggregation of the data reveals that $74 \%$ of all products manufactured in Central Falls are marketed outside Rhode Island. A significant 
majority of the city's firms, then, rely on export markets, meaning Central Falls' industrial base is influenced more by national economic trends than local economic development policy. An alternative view of this data is that many firms are not tied to a location in Central Falls, and can do business elsewhere. Significantly, $46 \%$ of the city's firms have no sales within Rhode Island, and $38 \%$ have no sales in Southeastern New England.

Central Falls' industrial marketing strategy should take two forms: retain existing firms with stable employment and production histories, stimulate reinvestment in plant and equipment; attract small firms engaged in the manufacturer of durable products related to modern technologies (biological products, medical and scientific equipment, computer components, electronics and electrical equipment, etc.). In conducting a market analysis for specific industrial projects, local planners should consider these points to better utilize existing resources. Efforts should be directed at those projects that will result in real economic growth for the community, rather than serving to delay the closing of firms that no longer can compete in their respective markets.

PROJECT IDENTIFICATION

Projects are identified by developers in a variety of ways. These range from very informal discussions by 
developers and local officials on the manner in which a problem should be handled, e.g. the need for industrial space, or the need to diversify the industrial mix, to a formal planning process in which problems, goals, resources, and strategies are all identified and systematically considered. 5 Local officials can stimulate a project by such actions as land assembly, rezoning, financial incentives, and provision of public facilities (parking, roads, sewers). Assembling a specific package of incentives for a given site can overcome certain market deficiencies, and make a project feasible. 6

Currently, the Special Task Force for Industrial Development is reviewing data for the purpose of identifying some special projects. Some of these projects require public action to develop certain sites. Others require reliance on the private sector. Examples of such projects will be described in later sections of this chapter.

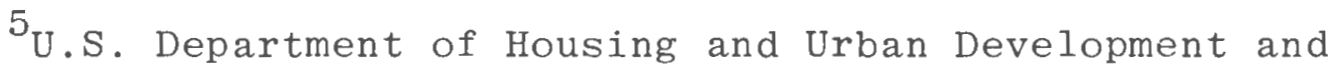
U.S. Department of Commerce, The Private Economic Development Process - A Guidebook for Local Development, (Washington, 1979), p. 24

${ }^{6}$ Deficiencies in these actions have been cited by Derthick (1972) and Cornia (1978). Specifically, assembling large tracts of land for development in a dense urban area is costly and tedious. Delays often aggravate the already high costs of construction. Also, financial incentives (tax concessions, interest subsidies) are insignificant in comparison to other costs (1abor, energy, raw materials) and only influence location decisions in the final phases. 
SITE ACQUISITION

Site assembly generally is accomplished in four basic ways:

(1) Agents for the developer acquire the necessary parcels as quietly and as quickly as possible to hold down price speculation among current owners.

(2) Real estate speculators slowly acquire properties as they become available until the resulting assemblage is suitable for new development.

(3) The property owners assume equity interests in the new development based on the values of their property contributions.

(4) The city uses its power of eminent domain to assemble the site which is then sold or leased to the developer for the project. ${ }^{7}$

In Central Falls, site acquisition is a particularly difficult problem for several reasons. First, because of its density, parcels of land are often too small, have poor access, or are not we11-adapted to redevelopment for industrial use. Secondly, vacant or undeveloped land is often in the hands of owners who have no incentive to sell it.

${ }^{7}$ U. S. Department of Housing and Urban Development and U. S. Department of Commerce, The Private Economic Development Process - A Guidebook for Local Development, (Washington, , 1979), p. 25 
Taxes are low, and each year the value of the land appreciates because of surrounding development pressures. Thirdly, the city's land use policies are often at odds with local economic development objectives. Variances for non-conforming uses have been granted without considering the implications in the city's manufacturing base. Therefore, the value of industrial land is artificially inflated.

The city's planning staff can act to overcome these problems by serving as a clearinghouse for available industrial sites, by acting as a broker to bring together buyers and sellers, and by using limited financial resources to help write down land costs. Finally, the city can plan to make certain public improvements to increase the potential of several underutilized parcels.

\section{NEGOTIATING THE PROJECT}

Most development in Central Falls requires extensive negotiations with local government. From local government's point of view, this provides an ideal opportunity to influence development in the community and turn it towards public goals as much as possible. Unfortunately, this opportunity can evolve into a bureaucratic nightmare for the developer if the regulatory process created to direct development towards public goals becomes cumbersome. 
In many parts of the United States, obtaining the necessary approvals to construct a project has become an increasingly difficult process for private developers. Typically, the zoning, sub-division, and other regulations operating in municipalities have not kept pace with the changes in demand in a given area. 8 In Central Falls, where vacant industrial land is at a premium and most industrial buildings were constructed before building and zoning codes were enacted, adherence to modern regulations is difficult and cost prohibitive. Due to the increasing complexity and uncertainty of the public permitting process, obtaining the necessary legal approvals and permits for new construction or renovation has become an increasingly larger factor in the development process and is weighed more carefully by developers now than in the past. As the major actor in administering the development permitting system, local government is in a position to influence the manner in which the system affects development. Specifically, local government can influence the risk that the front end investment in land options, analysis, and plan preparation may be lost, the direct costs of submissions and negotiations, and the overhead interest, and

${ }^{8}$ U. S. Department of Housing and Urban Development and National Community Development Association, Creating and Implementing an Economic Development Strategy, (Washington, 1980), p. 15 
other carrying costs during the time of public review and processing development applications. 9 The city, by acting to reduce these three variables, can encourage development, yet preserve the objectives of its regulatory system.

Recommended improvements are as follows:

(1) Improve the coordination among the various departments involved in the process. In Central Falls, development proposals are reviewed by the Building Inspector's Office for compliance with building codes and zoning regulations. The Division of Planning is consulted only when the proposal requires some action by the Zoning Board. On the other hand, development initiated by the Division of planning is not usually coordinated with the Building Inspector's Office. Consequently, a developer sometimes encounters conflicting positions on a specific project.

(2) Articulate clearly the city's development objectives and policies regarding development. This will reduce conflicting policies and corresponding regulations within government and give the private sector a clear indication of the consistency of a particular project with city policy.

${ }^{9}$ Ibid, p. 15 
(3) Maintain development ordinances in a way that accommodates current development practices and market conditions. Review of Central Falls' zoning ordinance requires a re-assessment of parking and setback requirements, given the density and shortage of vacant land.

(4) Anticipate problems with certain types of development and resolve the problems before development applications are submitted.

In general, the private sector is particularly sensitive to the political and regulatory environment and any steps local government can take to make that environment more accommodating will assist in promoting Central Falls' economic development objectives. PLANNING, DESIGN, AND ENGINEERING

Detailed plans and specifications are seldom developed before a project receives municipal approval. This work is very costly, and developers do not want to incur high expense on mere speculation. Local officials can have a considerable influence on planning and design work. The availability of water, electricity, telephone services, and sewer services is a key requirement for development. In Central Falls, such services are provided by public agencies and utility companies, with service availability controlled by the city. The major assistance which local government can offer regarding service provision is to undertake the 
necessary planning and investment to ensure that adequate capacity exists in the various service systems to accommodate new development. ${ }^{10}$ This is particularly important because the lead time on major service system development is often lengthy; lack of capacity coupled with long lead time to increase capacity may result in the loss of a development opportunity.

In addition, since virtually all projects require a convenient linkage into the transportation system which serves the area, and since local and state governments are responsible for developing and maintaining streets and highways, as well as regulating system access and operation, local and state governments play a critical role in determining whether and how the city's industrial areas will be linked to the transportation system. Given the importance of access to the location of industrial activity, it is particularly crucial that transportation system planning and investment be sensitive to the city's industrial development strategy and needs.

\section{FINANCING}

This report has given significant attention to financing's role in the development process in previous sections. Typically, a developer has three types of

${ }^{10}$ Ibid, p. 16 
financing to arrange: land acquisition, construction, and permanent. There are two potential sources: equity investors and debt lenders. ${ }^{1}$ Faced with a highly competitive market for capital, many projects that would be beneficial to Central Falls cannot attract the necessary financing from the private market at normal interest rates. This, however, may be less true for industrial development projects than for other types of development that depend on the local market for their success. As indicated previously, many of Central Falls firms have regional and national markets for their products. However, some banks take a more conservative view regarding the potential of run-down mill space or vacant industrial land. 12

Given this situation, local government can assist in making financing available in several ways. They can provide it directly, by subsidizing the interest rate, by assuming part of the investment risks, or by providing other incentives to lending institutions such as depositing large amounts of public funds. In Central Falls, it is recommended that the city continue to make available CDBG funds to reduce interest costs. Moreover, the city should

${ }^{11_{\text {Ibid, }} \text { p. } 17}$

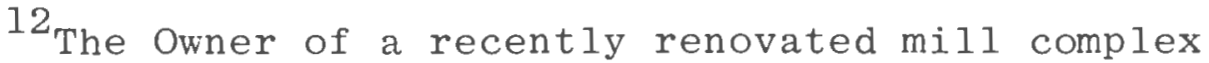
reported a certain banks unwillingness to finance the acquisition and renovation of the mill despite his firm's strong credit background. 
explore the possibility of depositing some of its federal funds in return for certain concessions from local banks. Finally, the city should prepare an application for UDAG funds to establish a revolving loan fund for the rehabilitation of industrial buildings and the purchase of new equipment and machinery. UDAG funds could be used to "write-down" current interest rates.

CONSTRUCTION

The construction phase of a project is probably the most risky, but also the most systematized. The risks derive from the uncontrollability of certain factors weather, labor supply, materials, etc. The actual work, however, is detailed in construction plans and specifications.

The ideal role of local government in the construction process is to perform its permitting and inspection functions in a conscientious and orderly fashion. The Building Inspector's Office should carry out its mandated functions without imposing undue delays and causing unnecessary costs. MARKETING

The City of Central Falls can play an ever increasing role in the marketing of new development projects in the community. Both through the preparation of promotional literature, and through personal contact with company officials, the city can assume a responsibility for keeping 
existing businesses and attracting new ones.

Presently, the Special Task Force for Industrial

Development is working with city officials to formulate a marketing program to improve the general perception of the city by the business community. The expected results of this work are an Inquiry Response Kit and marketing efforts on individual vacant or underutilized industrial parcels.

\section{EVALUATING DEVELOPMENT PROJECTS}

Local government agencies need to make every effort to insure that their limited funds are spent as effectively and economically as possible. This requires that local development agencies carefully evaluate every investment alternative in an attempt to maximize the overall public benefits of the economic development program while minimizing its cost. 13 In developing a model to measure costs and benefits, reference is made to the factors considered by HUD's Urban Development Action Grant evaluation staff. The criteria used to evaluate UDAG proposals are as follows: ${ }^{14}$

13 National Model Cities Community Development Directors' Association, A Guide to Local Economic Development Planning and Implementation, (Washington, 1976), p. 32

${ }^{14}$ Bureau of National Affairs, Report of the Bureau, Competing Successfully for Action Grants, (Washington, 1980), p. I-9 
(1) Private Sector Leverage - The ratio of private investment to public investment

(2) Permanent Employment - Number of permanent jobs created by the project; public cost per job

(3) Tax revenue generated

(4) Repayment of public funds to the city

(5) Impact on low and moderate income population Commitment to train and employ the unemployed, particularly minority residents.

In addition, HUD project evaluators look at the degree of commitment by the private developer and the length of time the project will take.

The real economic development benefits of the development come after the buildings have been completed and the land developed. Increased permanent employment, tax rate tables, and general business activity can only be measured after a building is in use. Local officials must be concerned whether new development results in an improved economic base or merely a shift in the component parts of the base.

The following estimates of industrial development impacts are highly generalized and were taken from a table comparing the impacts of various types of development. 15

${ }^{15} \mathrm{U}$. S. Department of Housing and Urban Development, and U. S. Department of Commerce, The Private Economic Development Process, (Washington, $\overline{1979), ~ p . ~} 32$ 
Type of Real Estate Project - Industrial

Employment Benefits

Number of job varies from ten to fifty $(10-50)$ per acre, with distribution activities at low end and labor intensive industries at high end. Important considerations are skill levels and wages; also new jobs created versus those displaced. Industrial jobs foster one to two times more jobs of other kinds. Thus, potential economic benefits are great.
Tax Base Benefits

New industrial development costs $\$ 200,000$ to $\$ 600,000$ plus equipment per acre, depending on floor area to land ratio, type of building, and type of industrial activity, e.g. warehouse space is inexpensive compared to research and development space.

These benefits and considerations must then be compared with the costs the city incurs for the project. Briefly, these are as follows: ${ }^{16}$

(1) The amount of the subsidy which the city must provide to implement the project.

(2) Any increased cost the city might incur in providing public services to the project.

(3) Negative influences of the project on neighboring development (traffic, parking, property values)

(4) Negative influences of the project on the city's economy or physical and social environment (noise, air pollution, blight, water consumption)

${ }^{16}$ National Model Cities Community Directors' Association, A Guide to Local Economic Development Planning and Implementation, (Washington, 1976), p. 33 
To these must be added the opportunity cost, that is the cost of foregoing opportunities that might be possible now or in the future. Assuming there are more desirable projects than the city's Community Development funds allow it to implement, the city must consider whether investment in a given project represents the best investment that could be made with the funds available.

In summary, Central Falls, through its Division of Planning and Community Development has the ability and resources to assist in the implementation of projects to benefit the local industrial base. However, the resources are limited. Therefore, the city should adopt a philosophy to guide its investment of public funds. This philosophy should attempt to do the following:

(1) Minimize public dollar investment as a portion of development cost in any given project.

(2) Minimize the time period of its involvement in a given project. The shorter the period of time over which Community Development funds are involved in a project, the sooner its funds will be free to invest in other projects.

(3) Give the highest priority to projects that generate an on-going investment in the community without further involvement by the city. For example, assist new or existing firms that have growth potential and will make continued investment in plant and equipment. 
(4) Select projects that complement one another so that the success of one project makes the success of the others undertaken by the city easier to achieve; select projects within the context of an overall strategy.

\section{ILLUSTRATIVE PROJECTS}

This section contains descriptions of actual or proposed projects that illustrate the recommendations outlined previously. Two of the projects involve public improvements to accommodate private development of manufacturing areas in the city. These descriptions are followed by three private development projects that are representative of a sound industrial development strategy.

\section{(1) Higginson Avenue Area}

An area on the west side of the city which may have industrial potential is located on Higginson Avenue, adjacent to the Mohassuck Industrial Highway. The area consists of approximately thirteen (13) acres, most of which is privately owned. However, there are a number of factors which prevent the immediate development of much of this area. A drainage problem is foremost among these. Storm sewer overflow from a large portion of the city is currently released into a drainage ditch, causing much of the area to be subject to flooding. A swamp at the south end of the area compounds the problem. 
This area represents the largest portion of vacant industrial land in the city. With the presence of the Industrial Highway and the resurrection of the ProvidenceWorcester rail line, the access to the area is excellent. As mentioned, much of the area is subject to flooding. Moreover, the area is a designated wetland. Reports indicate, however, that development is possible if adjustments are made to reduce the storm overflow into the area, and if the swamp is drained and filled. A coordinated effort is needed to undertake a study to determine the feasibility of developing this area. Elements of this study should include an assessment of the drainage problems, soil borings, a site survey, environmental impact analysis, and recommendations for possible solutions. Such a study would cost less than $\$ 20,000$, a small sum given the great potential benefits from a thirteen (13) acre industrial park.

\section{Reconstruction of Railroad Bridges}

Central Falls has access problems because it is a densely developed city. The city is bounded on the east by the Blackstone River. The city's most concentrated manufacturing area runs along the river. While much of it is developed, there are two large parcels of vacant land and several smaller underutilized sites. A major problem is access to the area. All vehicular traffic must travel under or over the Penn Central Railroad tracks. 
Of four entrance points, only one is accessible to trucks, the entrance that goes directly over the tracks on Hunt Street. The other three entrance points are low, narrow tunnels under the tracks. Thus, the area is effectively isolated for large truck traffic.

Before the area can be expected to reach its full industrial potential, these underpasses should be enlarged. The Railroad has not included this project in its Northeast Corridor Improvement schedule. Apparently, the city has not requested their inclusion. The city should obtain cost estimates for reconstruction of these bridges and explore the option of sharing the cost of the project with Penn Central. The city's share could be paid for by an Action Grant. While reconstruction costs might be substantial, the long term benefits of development of two or more parcels and retention of over six established firms demands further investigation.

3. Recycling of Old Industrial Space - Narragansett Braid Mill

FKC Engineering Corporation, founded in 1960, assembles electrical components for the aerospace, military, and marine industries. The firm, originally located in a nine-thousand $(9,000)$ square foot building in Pawtucket, required additional space for its operations in order to meet the increasing demand for watertight 
electronic equipment used on weapons systems, the offshore oil industry, and other marine-related industries. FKC wanted to remain near Pawtucket to retain its skilled work force of about fifty (50) employees.

In 1980, the firm located an old textile factory, the Narragansett Braid Mill, in Central Falls. The Narragansett Braid Company had gone out of business and FKC was able to acquire 52,000 square feet of space at a total purchase and renovation cost of about $\$ 300,000$. In order to expand its operation, FKC required working capital to hire an additional forty-five (45) employees and purchase materials for component assembly.

Because of Central Falls' Economic Development Program, and in conjunction with the Ocean State Business Development Authority, a financial package for purchase and renovation costs required FKC to invest on $1 \mathrm{y} 2 \frac{1}{2} \%$ of project cost as their equity in purchase and renovations. This freed up other FKC funds for working capital. The OSBDA worked with FKC to assemble the other $97 \frac{1}{2} \%$ of project cost. The sources of capital in the package were the following:

--A first mortgage loan, amounting to $60 \%$ of project cost, provided by a commercial bank for a term of twenty (20) years at an interest rate of prime, plus $1 \%$. 
--A subordinated loan, amounting to $30 \%$ of project cost, provided by SBA for a term of twenty (20) years at an interest rate of $8 \frac{1}{4} \%$.

--A loan for $7 \frac{1}{2} \%$ of project cost, provided by the City of Central Falis at a rate of $8 \frac{1}{4} \%$ for twenty (20) years.

- A building improvement grant provided by the city from its CDBG funding,

The costs to the city were $\$ 18,750$ with $\$ 10,750$

to be repaid over twenty (20) years. The benefits are a recycled mill building, $\$ 300,000$ in private investment, forty-five (45) new jobs, tax revenues $(\$ 8,351$ per year), renovation of an old theater which is part of the complex, and increases in retail sales in the nearby commercial district. Also, the city will benefit from an improved image throughout the Blackstone Valley and the state.

\section{Plant Expansion - Whittet_Higgins Company}

Whittet-Higgins Company has two metal-working plants in Central Falls, Whittet_Higgins and the William Collins Company. Whittet-Higgins manufactures bearings and other high-precision metal products. The firm hires and trains people to be high-precision metal workers, and presently employs over fifty (50) people. Their wage rate is above the national median for production workers, and is almost two (\$2.00) dollars above the average hourly earnings of a 
production worker in the apparel and textile industries. Whittet-Higgins has a national market for its products and is presently in a position to expand.

In the fall of 1980 , local officials received information that Whittet-Higgins had inquired about space in an industrial park in Lincoln, Rhode Island. Recognizing the importance of keeping these plants in Central Falls, they sought to work with the company's management to help them expand at their present site. Located on Higginson Avenue, Whittet-Higgins is bound on the east by a vacant lot and on the west by an auto reconditioning business. Expansion plans call for the construction of a 10,000 square foot addition. This would allow the firm to expand its production capability and hire more workers.

The obvious solution was the vacant lot, located east of the existing plant. However, lease options and an existing sewer line prevented acquisition of the site. The alternative was to buy out the auto reconditioning plant. When the city became aware of the situation, negotiations between the two parties had ceased and Whittet Higgins was threatening to relocate in Lincoln. In an effort to facilitate negotiations, the city offered to obtain the services of an independent appraiser to determine the current market value of the property occupied by the auto reconditioning firm (LIVCO Auto Reconditioning and Repair). In addition, 
an alternative site for LIVCO had been identified and the city offered to develop cost estimates for relocating LIVCO at the proposed site. Both parties seemed satisfied with this plan.

The results of this effort were mixed. Relocation costs were determined to be approximately $\$ 201,000$. The appraisal value of LIVCO's plant and land was determined to be $\$ 110,000$. While Whittet-Higgins was willing to pay a premium for the site, a purchase price could not be agreed upon. However, the city's effort to force an agreement had demonstrated to the management of Whittet-Higgins that the city realized their value to the community and, given time, could perhaps assist them in remaining in Central Falls. An alternative plan has been developed whereby Whittet-Higgins will consolidate its operations at the present site and relocate its shipping-receiving and subsidiary operations at another site. Whittet-Higgins is presently working with the city's economic development staff to identify a suitable site for the construction of a 20,000 square foot building and a shipping facility.

\section{New Construction}

There are presently two sites located on High Street that merit inclusion in the city's industrial development strategy. Both sites are large, have good access, are 1ocated in a manufacturing area, and represent good opportunities to attract new firms in Central Falls. The first is 
Plat 2, lot 39. This site occupies 112,000 square feet, has an 80,000 square foot building with loading platform, has a large parking area, and is not in use. Plat 2, lot 52, occupies 114,000 square feet, and has a 28,000 square foot building. This site is presently being used to store construction equipment, an unproductive use with little benefit to the city.

It is recommended that the city, through its special Task Force for Industrial Development, contact these owners and inform them of the city's efforts to revitalize its industry. They should be made aware of the limited land available for industrial development, and urged to work with the Task Force and the Chamber of Commerce to put this land to a better use. Through a combined effort, the sites could be packaged and marketed, with an eye on producing jobs and revenues for the city and a reasonable return for the prospective owners. Central Falls should also enlist the assistance of the State Department of Economic Development in marketing these parcels. 
CHAPTER V.

CONSTRAINTS AND SUMMARY RECOMMENDATIONS 
The 1970's have seen many communities throughout the country become more actively involved in solving their economic problems. This trend has been especially prominent in the Northeast, where disinvestment strategies, labor problems, imports, rising energy costs, and other factors have made government intervention necessary. Central Falls' economy has experienced a gradual decline over the past thirty (30) years. This trend can be linked to the decline of the textile and apparel industries in New England. Central Falls has lost eighteen (18) firms in the textile and apparel industries in the last thirty (30) years. ${ }^{1}$ Yet, these industry groups still account for $55 \%$ of all manufacturing employment in the city. ${ }^{2}$ Such a high dependency on textiles limits the growth potential of Central Falls' economy. Moreover, wage surveys reveal that the average hourly earnings of production workers in textiles and apparel are at the bottom of the wage scale, effectively limiting the amount of disposable income available for housing and consumer goods. 3

${ }^{1}$ Rhode Island Department of Economic Development, Report of the Department, Directory of Manufacturers', (Providence, 1950, 1972, 1980)

${ }^{2}$ Rhode Island Department of Employment Security, Report of the Department, 1980

$3_{U}$. S. Department of Labor, Handbook of Labor Statistics, 1978 
As other communities initiated public economic development efforts, planners and elected officials in Central Falls realized the benefits of economic growth in all aspects of community life. Over the past ten (10) years, Central Falls has assumed a more active role in strengthening its industrial base. Early efforts consisted of urban renewal programs to acquire and clear land for sale to private developers. History has proven this approach to be costly and ineffective. Acquisition, demolition, and site preparation required large public investment, often without any commitment from the private sector. Moreover, land clearance activities often had devastating effects on the surrounding neighborhood. The East Side Neighborhood Development Project in Centṛal Falls, where three blocks of housing were demolished to construct a beverage warehouse and a boat storage facility, is an example of the failure of the urban renewal approach. Neither facility has resulted in substantial employment.

When urban renewal programs were replaced by Community Development Block Grants, Central Falls shifted its focus to the rehabilitation of its housing stock and public facilities (infrastructure, public buildings, playgrounds, etc.). The economic development program was targeted at the city's commercial districts. Funds were used to conduct a market survey, make public improvements, organize the merchants, and provide grants for facade improvements. Little attention 
was given to local industry. In my opinion, this was a serious oversight, for Central Falls' manufacturers are the foundation of the city's economic base, employing over $70 \%$ of its work force and paying $25 \%$ of its tax revenues. ${ }^{4}$

\section{PROGRAM SUMMARY}

In the preceding chapters, I have outlined a comprehensive Industrial Development Strategy for Central Falls. This strategy consists of the following four elements: research and technical assistance, organization, special projects, and marketing and promotion. These elements represent a model which public and private officials can use to identify priorities and develop programs to address the needs of local industry. The Division of Planning and Community Development (DPCD) will play a significant role in the implementation of this strategy. DPCD will provide staff support, coordinate the allocation of public resources, including financing, and represent the city's interests in any negotiations.

The city has allocated $\$ 130,000$ of its Community Development Block Grant funds for economic development. Specifically, these funds will be used as local "injection money" in financing projects through the Ocean State Business Development Authority. Typically, the city's participation in a project will not exceed 5\% of the project cost

${ }^{4}$ Central Falls Division of Planning and Community Development, Report of the Department, 1980 
and will be loaned at below market rates. In addition, these funds can be used to conduct technical studies (architectural, engineering, financial analysis) and marketing efforts.

Organizational efforts are also underway to increase involvement in local economic development. The Special Task Force brings the expertise of the local manufacturers and the financial community to this effort. The Task Force will review the existing data, identify opportunities and constraints, and work with the city to develop certain sites. Development will occur through two other organizations; the Second Pawtucket Industrial Foundation and the Ocean State Business Development Authority. The Industrial Foundation, the development arm of the Blackstone Valley Chamber of Commerce, usually involves itself in speculative ventures and has considered doing a project in central Falls.

UPDATE - ISSUES AND PROBLEMS

Currently, Central Falls has made considerable progress in implementing this strategy. The Division of Planning has researched the condition of local industry and prepared reports on existing trends and specific needs and problems. The Division has surveyed existing industrial space and maintains an inventory of available space. The Division has also established a mechanism through which local 
manufacturers can obtain ninety (90\%) percent financing at below market rates. Finally, the Division has been successful in its organizational efforts to involve the private sector and is now working with the Task Force to analyze specific development opportunities and formulate a marketing strategy .

A number of problems exist, however, which will act as constraints on the overall industrial development strategy. The first constraint is the lack of available land suitable for industrial development. Surveys of the industrially zoned land in Central Falls have identified only one undeveloped area (Higginson Avenue) and a few underutilized sites (High Street). The Higginson Avenue site would require sewer and road construction, and would require considerable involvement to assemble the land. The other sites on High Street have poor access and would require some renovation to adapt them for heavier industrial use. A second problem is the poor image that Central Falls has in Rhode Island. The city has been the poorest community in the state for the past twenty (20) years. Its housing stock is deteriorating and lacks variety and its business and industry are declining. Despite gains made in all these areas over the last decade, the city retains its image as an undesirable place to live and work. Because of 
these image problems, efforts to revitalize local industry encounter considerable resistance. In fact, characteristics which are seen as problems by some, e.g. old industrial plants and unskilled labor, are viewed as positive locational factors by much of the industry in Central Falls. Inexpensive industrial space and a large pool of unskilled workers are reasons why many of Central Falls' firms are located in the city.

A third problem is the weak market demand for industrial development in Central Falls. While this weak market is related to the shortage of industrial sites and the city's poor image, the nature of this problem calls for further explanation. Training literature on economic development strategies maintains that the two primary responses of local government to weak market situations should be demand creation and cost reduction. 5 A public objective to promote economic activity in a weak market situation requires substantial public investment. The two responses, which both require a heavy commitment, are appropriate because they attack the market problem which forbids private

${ }^{5} \mathrm{U}$. S. Department of Housing and Urban Development, National Community Development Association, U. S. Conference of Mayors, Creating and Implementing An Economic Development Strategy, (Washington, 1977), p. 21 
investment, namely, a demand price below a supply price. 6 Demand creation techniques include public lease of space, user-financing, and public improvements. Similarly, cost reduction techniques include property write-downs, and tax exemptions and abatements. Other appropriate techniques in weak market situations relate to investment of public dollars in one form or another. As mentioned previously, Central Falls has a limited amount of public dollars available for any program. Tax revenues are almost exclusively utilized to provide municipal services, such as police, fire, schools, and local government operations. The city receives additional funds through HUD's Small Cities Program, but only $\$ 30,000$ per year is allocated for economic development. These financial restraints reduce the impact public efforts will have on the industrial base.

${ }^{6}$ Ibid, Article references in Chapter III (Cornia, 1978 ) argues against this point. Cornia states that cost considerations (labor, energy, construction, transportation) and market factors are far more important than tax and fiscal incentives in influencing location decisions. However, fiscal incentives can influence a firm once it has decided to locate within a region or metropolitan area. At this phase of the decision process, Central Falls can attract firms with appropriate public investments. 
Another significant constraint on the implementation of this economic development program is the city's lack of experience in administering such a program. The Central Falls' Development Program operates out of the DPCD which only has responsibility for those activities under the Community Development Program and has little control over other departmental policies. Further, examination of a priority list, as outlined in a Report of the New England Conference on Economic Development indicates Central Falls is lacking in each of the following areas: ${ }^{7}$

(1) Economic development policies supportive of long-range, comprehensive plans for community growth

(2) Planning and management experience implementing strategies to accomplish development objectives

(3) Working relationships with an understanding of non-municipal, quasi-public and private interests

(4) Experience testing innovative approaches to local economic issues and experimenting with new development techniques

Central Falls has not defined industrial development as a growth priority and therefore, initiatives in this area are sporadic and inconsistent with city policies. There is not enough active policy support from the Mayor and the Council for an aggressive development effort. An aggressive

${ }^{7}$ New England Municipal Center, proceedings of New England Conference on Economic Development. 
leadership role by elected government officials is essential. As a result, DPCD is pursuing development strategies on its own. This uncoordinated and leaderless atmosphere often frustrates public and private officials and weakens the confidence of prospective private developers in the community .

An example to support this point is the awarding of a variance by the Zoning Board for the construction of elderly housing in a manufacturing zone. ${ }^{8}$ The particular site is vacant and located in an industrial park. Both the Mayor and the Zoning Board were acting in direct opposition to the policies developed by DPCD. A second example is the recent formation of the Special Task Force for Industrial Development. The Mayor has not given the Task Force a specific mandate nor has he exercised the leadership such a group requires to be productive.

The city's limited capability to work with the private sector and inadequate assistance from the State Department of Economic Development constitute two other problems which impede the progress of the economic development program. As indicated, previous efforts to stimulate industrial development have lacked the support of the private sector. Limited resources and experience have

\footnotetext{
${ }^{8}$ Central Falls Zoning Board, Variance granted to Plat 8, Lot 330, August 27, 1979
} 
caused economic development planners in Central Falis to link their efforts more closely with the private sector. The recent establishment of the Task Force is an attempt to involve the private sector (bankers, manufacturers) in the formulation of the city's industrial development policy. Injection of public funds must be tied to private investment. Yet lack of experience and appropriate mechanisms, together with the traditional view of government as a regulator, limits the effectiveness of the publicprivate partnership.

Finally, the State Department of Economic Development has offered little support to local governments in Rhode Island. Their programs are not tailored to the small manufacturer reinvesting in plant and equipment. In addition, most of the state's marketing and promotional activity is targeted at firms which are located overseas or in other parts of the country. Development projects are almost always in suburban industrial parks. While revitalization of "urban industries" is listed as a goal in Economic Development Strategy for Rhode Island, 1979 , the State DED all but ignores existing industry in the urban centers, e.g. Central Falls, Pawtucket, Providence. ${ }^{9}$

${ }^{9}$ Rhode Island Statewide Planning Program, Economic Development Strategy for Rhode Island, State Guide PIan Element 211, 1979 
INVESTMENT PRIORITIES

Critical policy questions must be addressed in the formulation of a sound economic development strategy. City officials must make some important decisions regarding the allocation of public resources. Policies concerning the incentives, zoning, land usage, and public improvements must be dealt with as part of the industrial development strategy. While these issues require careful research and discussion, with consideration of the tradeoffs involved, a number of short-term strategies should be considered. These strategies should focus on supporting firms that are currently operating in Central Falls to prevent their movement out of the city. Problems that have been identified by existing firms include dock loading, traffic access, employee parking, and rehabilitation of existing space. Long-term strategies should deal with more complex problems, such as tax policies, space available for expansion, energy conservation, skills training, public improvements, image, and development mechanisms. Both long and short-term strategies should be based on the partnership approach that links the government business, financial, and labor interests together as a team to serve mutual needs. Translating these ideas into action for industrial development is not a rigid process, but requires a certain 
flexibility to satisfy the many interests involved. Some recommendations are needed to initiate the process and guide the involvement of local government.

\section{Short-Term Strategies}

(1) Continue to work with the Special Task Force for Industrial Development; concentrate on issues and problems that can be addressed and which will result in immediate benefits. Strong mayor and council leadership must be enlisted.

(2) Develop a traffic and parking plan for the Roosevelt Avenue industrial neighborhood; focus on solutions which require limited resources and can be easily implemented.

(3) Complete inventory of available industrial space (land and buildings); review with the Task Force for possible target development.

(4) Research feasibility of developing Higginson Avenue for industrial use; compile existing studies and contract with professional engineering firm, if necessary.

(5) Initiate program to educate municipal officials (Mayor, City Council, Building Inspector, Tax Assessor, City Engineer, Public Works Director, Planning and Zoning Boards) on problems confronting local industry and proposed strategy to address these problems. 
(6) Circulate newsletter to business community documenting local industrial development efforts and programs at all levels of government.

\section{Long-Term Strategies}

(1) Develop Industrial Reinvestment Program; utilize existing data on needed building improvements to organize investment activity, utilize federal resources (UDAG, CDBG) to subsidize investment.

(2) Plan development project with Second Pawtucket Industrial Foundation; target effort at mill rehabilitation or new construction on underutilized industrial space.

(3) Introduce legislation to tax vacant commercial or industrial land at full value.

(4) If development along Higginson Avenue is determined to be feasible, assemble land and construct necessary site improvements to make this land marketable. (This effort could produce up to thirteen (13) acres of vacant land).

(5) Develop marketing and promotional program to attract private investment to Central Falls; link this program with site development.

(6) Establish a formal development mechanism for Central Falls; this might take the form of an economic development commission consisting of local government officials, and representatives from business and industry, labor, and the financial community; this group should be given 
authority to set policy, review development proposals, and control the utilization of public resources allocated for economic development.

(7) Lobby state DED to alter the focus as to consider needs of older, industrial cities, not just suburbs and exurbs.

\section{FUTURE PROSPECTS}

Central Falls is Rhode Island's smallest and poorest community. Because of its size and density, the city has little land for new development. The prospects for expanding the tax base are limited, given these constraints. Meanwhile, the cost of municipal services continues to rise. The residents of Central Falls, an increasing number of whom are on fixed incomes or earn low hourly wages, cannot afford tax increases. Reliance on federal support to supplement local revenues has allowed the city to maintain service levels and rebuild its public facilities. Cutbacks in federal spending, however, are likely to return the responsibility of providing services to the local level. Central Falls cannot afford to assume the responsibility without reducing services and raising taxes.

Current changes in federal policy are directed at stimulating growth in the private sector. A similar policy is needed in Central Falls, where local industry forms the foundation of the local economy. While growth potential is 
limited, local officials must adopt innovative approaches to encourage local firms to reinvest and expand where possible. Vacant and underutilized industrial space must be developed to provide jobs and tax revenues for the community. A strong manufacturing base is essential for the future of Central Falls as a viable community. By preserving existing employment and creating new job opportunities, residents of Central Falls will be able to support a full-time government and school system. They.. will be able to support the commercial district, and supply the investment to preserve the city's housing stock.

The adoption of a sound and consistent strategy to strengthen local industry is the first step toward building a productive partnership with the private sector. Central Falls must stop asking companies to stay within its boundaries and start making it in their best interest to do so. 
APPENDIX 


\section{$-118-$}
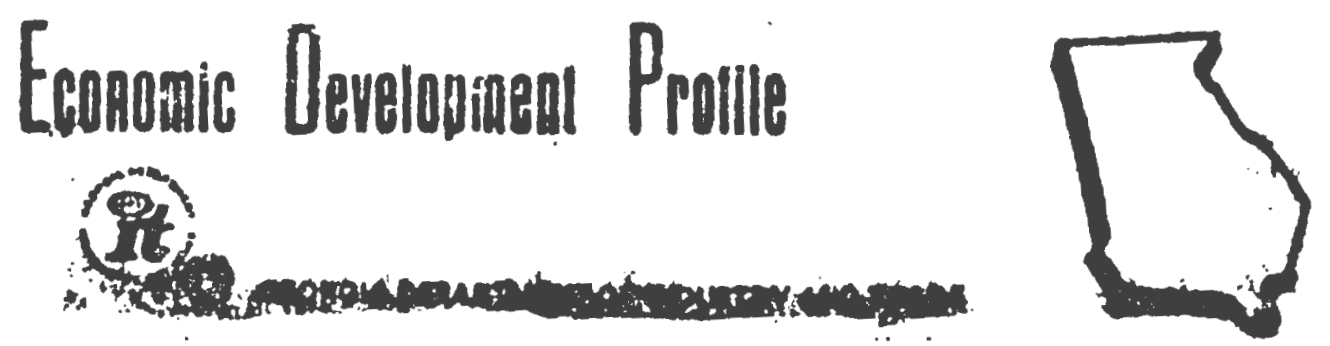

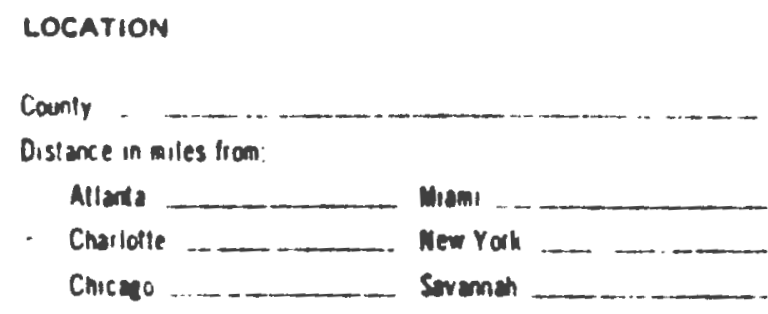

Population

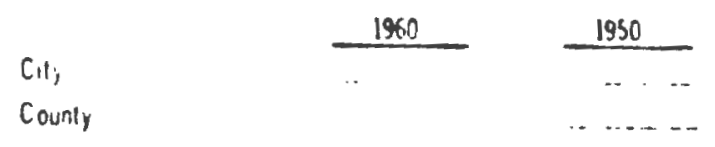

GOVERNMENT SERVICES

Troe of local goreinment:

Civy zoning recinance in effect ( ) yes ino

Counly coning ordinance in ellect. $($ lyes 1 ino

Subdivision ordinance with design standands in eflect.

$$
1 \text { iyes i ino }
$$

Number full.lite lice departme of dersonnel.

Murger vilid oel file decartmant aersornel

Fire insurane classilication

in crily

oulside cily

Aumber luillime policemen: city

counly

I willime bily engineer: ( Iyis I ino Licensed: ( I yes \& Ino

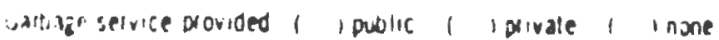

Pu: in lotaly: I yes 1 Ino

Posiallice in clly 1 , yes 1 , no

ll yes, cluss ol pust allice

\section{EOUCATION FACILITIES}

Pudic dementay and seconday schools

Munber of sohools in county

Entoliment grades 1 - 12

Muaba mos sonool gaduates anualy

Yocations education progreas in high schools

1 ) lind and industuce

1) busuness and allice

(1) Astidulion and serterine

(1) indertinat exts

Aies lectinical school

Nane

Locsion Eniolinenl

Junwi college

Nane.

Location Encoliment

Four-yez college

$$
\text { vine }
$$

Location Enoliment

Other educationat ixilities
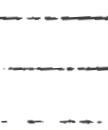

\section{COMMERLIAL SEAVICES}

Machine shoplsi a lyes i ino

tool and die senvicess: 1 ires I ino 


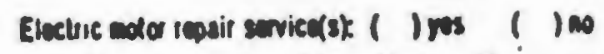

Tro a neweperer: ( Idaity I I weatly I the

$$
\text { ( ) now }
$$

Redio detion(s): ( ) wes I In mest:

number of TY chumals receivet:

Cole antems telovision serws city. ( Iyes I is

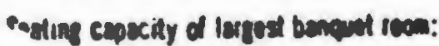

Soding capecily of Ingest endile ine:

Truval ecconacodations: molef loons

$$
\text { ..... - ... ndel roens }
$$

Nunter ol bains: . . . - Tolal assets:

Munter of sovines and lon assacidions.

Todal assets

Choter of conaerce: ( i yes 1 100

Manget is fulltine: 1 ives 1 ino

oner industrial developers:

Remariks:

\section{TAANSPORTATION SEAVICES}

RAIL

Railioxus): 1 I yes ( ino

name(s):

If no, distaxe to matest losding boin:

vilus

Puefrockservice: I Iyos I Ino

Reciprecalsmichine: I I yes I 100

WOTOR CARRIER

Inler-cily bus sevice: ( I yes I Ino

Hithway nubue(s): I cowal

Intersiza higumoy: 1 ives (1) ino

II no, distenco to noarest inlerchenge: miles

Number of acta freigh cerrers:

interstate

Number of nole freight caliews maint aining

local tominals:

\section{BARGE}

City ajouns aved ble rive: ( Iyes 1 ine

Nane of ine:

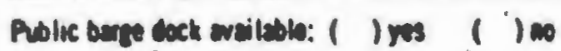

Chenal enpiti: inis

AlR

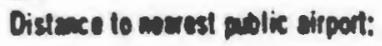
miles

Trpe of romer: ( ) ed I Ihad surice

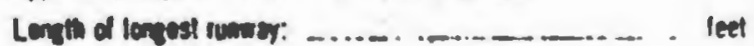

Rumery listhed: I I yes $($ ine

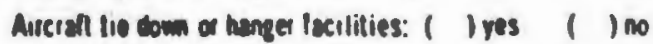

Awereft repain (cowes olent and/a arfiaso): ( ) yes ( ino

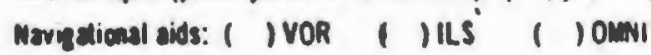

$$
\text { ( INOB I IGCA }
$$

Nezrest connetcial if tramporlation: miles

Laction:

Name(s) of sifline(s) serving point:

Length od line goods in trensil to:

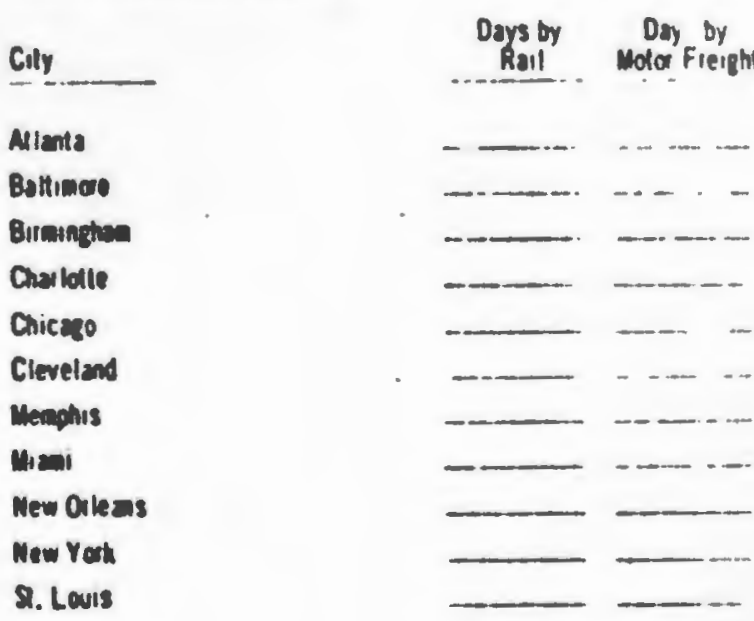

\section{ITILITIES}

\section{IATER}

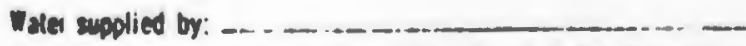
Dater suply aporoved by the Georia Deautent of Rolic Meallh:

1 inos 1 ino 
Capecily ul wallo plimit

Averape dusly risisumption:

uns num dinitr comsimpliox:

Dere of mourmitum

Aiver walm avalinise 1 ives 1 lino

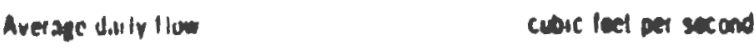

Late o seservolf I ives 1 ino liallous:

\section{SANITATIUN}

Trpe d stwage llexurent of ant

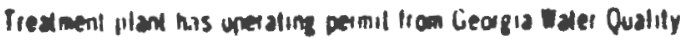

Coutrol Bans: I l ves 1 ino

Ouraclecislics of waste treatent pianl

Measulenen!
Gallons dei day
Population equivalen!

\section{MATURAL GAS}

Halval eas service: 1 i ves 1 ino

Hame of supplies:

Nane a disticibular

Blu conient

ELECTRICITY

Nane of subive

Nane of disilibuita

\section{LABOR MARKET ANF}

County.

Population idate

Civilien iaba lace

(annual average 196. 1:

Uneaployed

Unemployed as percenl of iator force

Tatat employtan!

Agricultua al employent

Non-agicultural emplovent

Munulaclutilig employment

Niw andulaclusting employment

llaln of lairsl buox mathel surver.

lianducied ur

kesulls avoulable male

owateble lemale

latal maldale

talions art ay

xallons

callons
$-120-$

Lerest mandactures in cily:

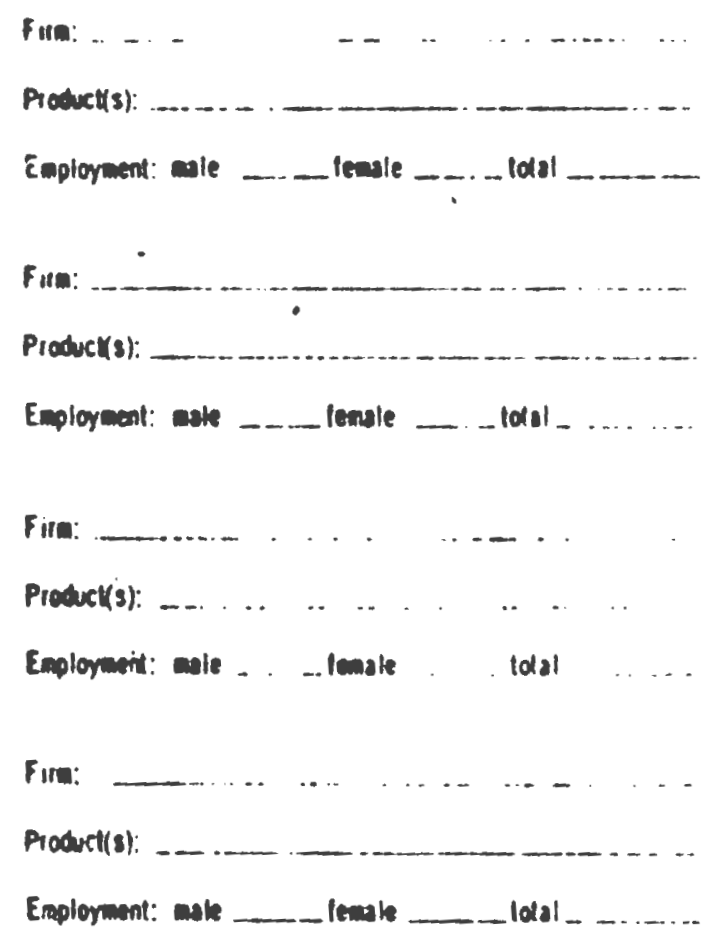

HEALTHFACILITIES

- . .

Nuaber of hospitals:

Muaber of beds: - _. . . . . . . . . . .

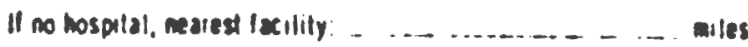

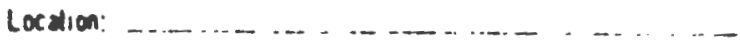

Public neath service: 1 I res 1 ino

Ornet facilities:

Munber of medical personnal.

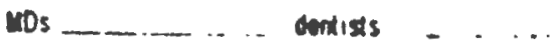




\section{RECREATION FACILITIES}

Fecilitios maildoie: I igoll coursus)

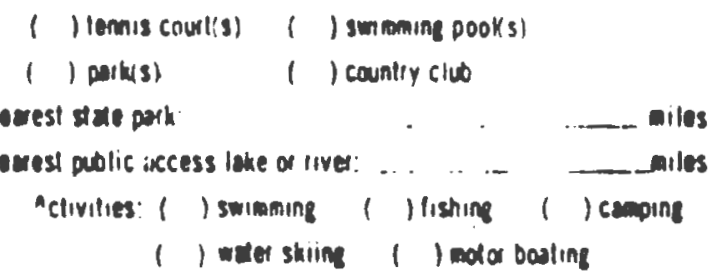

\section{TAX STRUCTURE}

Assessoment inio, cily moperly: _._. . . percent of real markal value

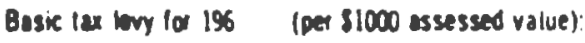
cilys .... . county .. . . states . . . lotals .........

\section{miscellaneous INFORMATION}

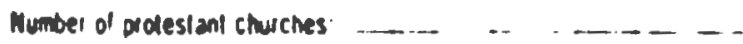
Romen Catholic chuch: 1 ives 1 ino

If no, disience to neares: anles

Jemsin temple a smagave $($ i nes ( ) no

II no. dislance to nearest:

Average cost if condiculion la residential nousing

S ... - .... . . - der saure lod

Outuanding communily awars, honoss a exhevenent:

$--\ldots .$.
INDUSTAIAL SITES AND INDUSTAIAL EUILOINOS

Tolal muber of indusinal stes matable

Tolal nutow of industrial buldines ovalable.

LOCAL INDUSTAIAL DEVELOPMENT OAGANIZATION

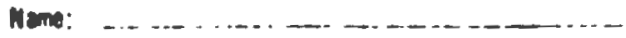

Local cont xet:

Muress:

Phene number:

Aiea code

PREPAREO BY

GEORGIA OEPARTMENT OF INDUSTRY AND THADE

P. O. Dox 38097, Allania, Georgie 30334 Ares Code $404-577.3450$ 


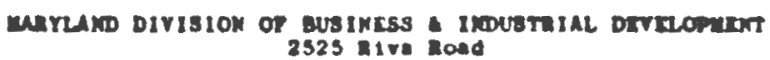

Annapolis. Warylend $\mathbf{3} 140 \mathrm{l}$

IDOUSTRIAL BITE NO.

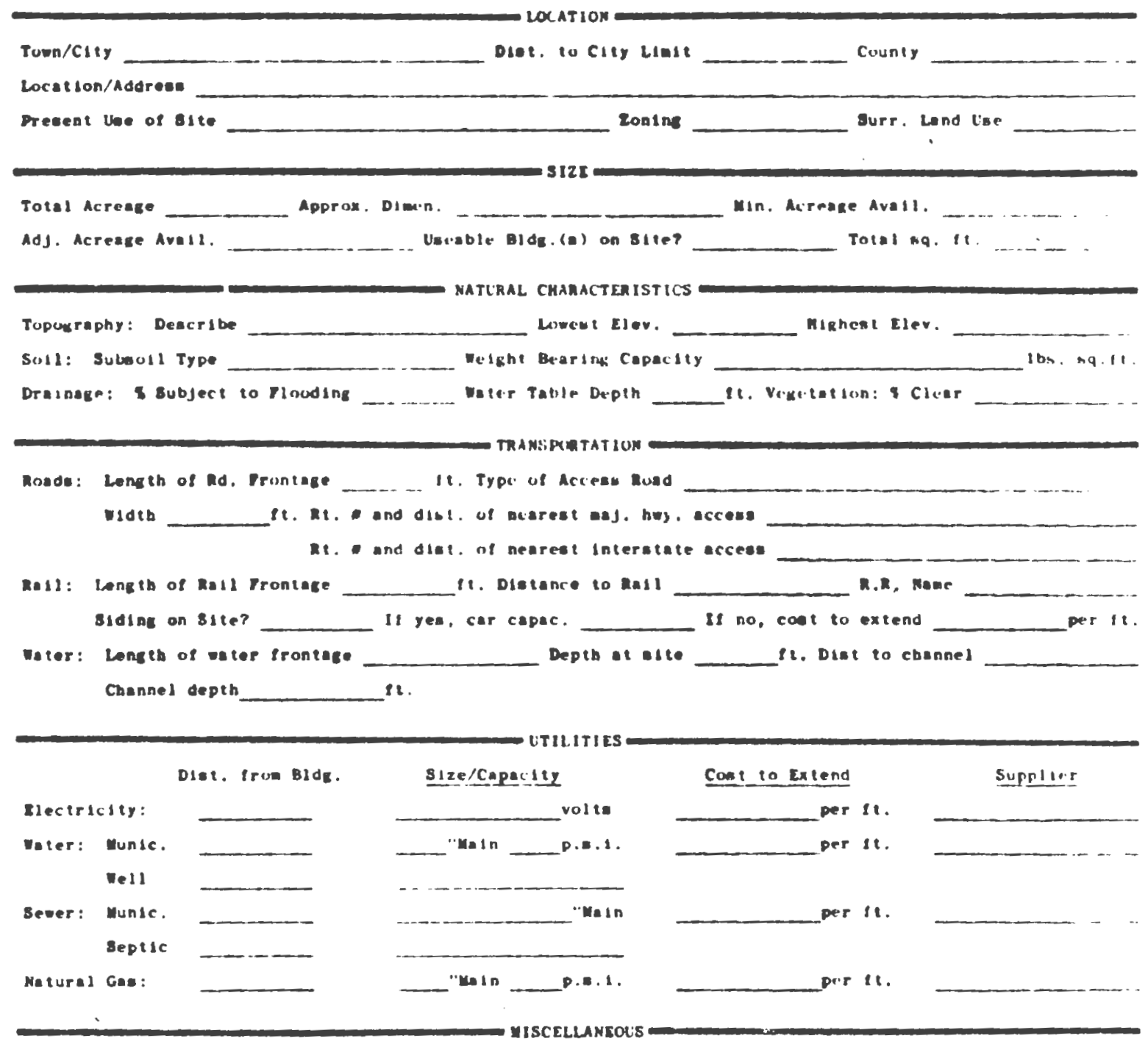

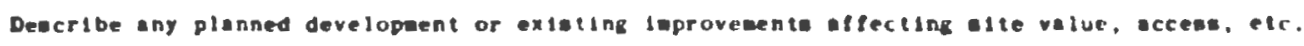

Dotosfpleternape Inclood (Circle). It mit, akelih property on reverae of aheet. 

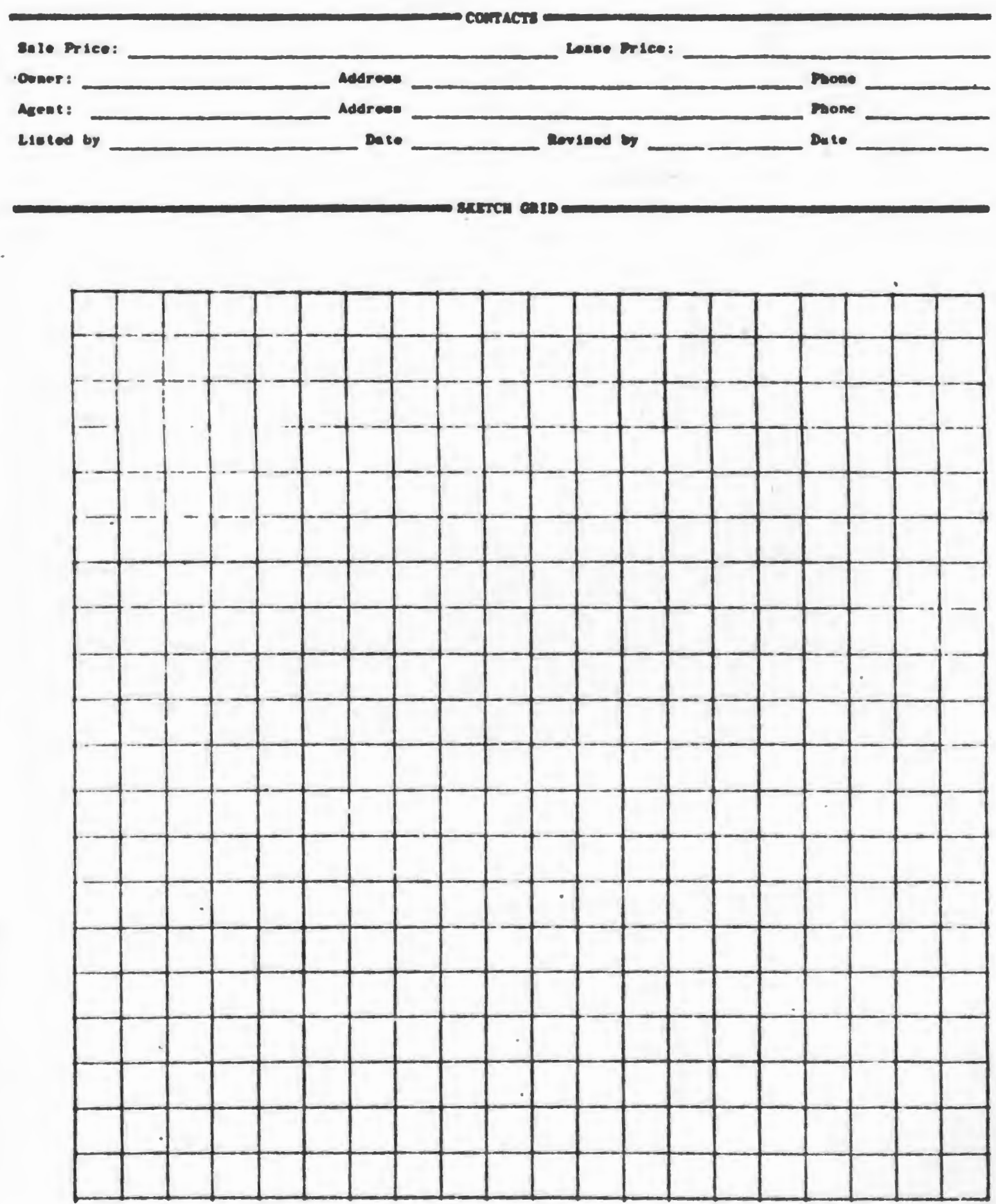


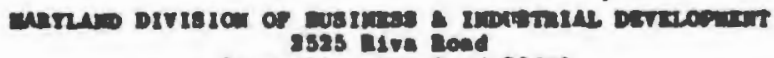 Anappols. Enrylaed 21601}

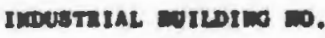

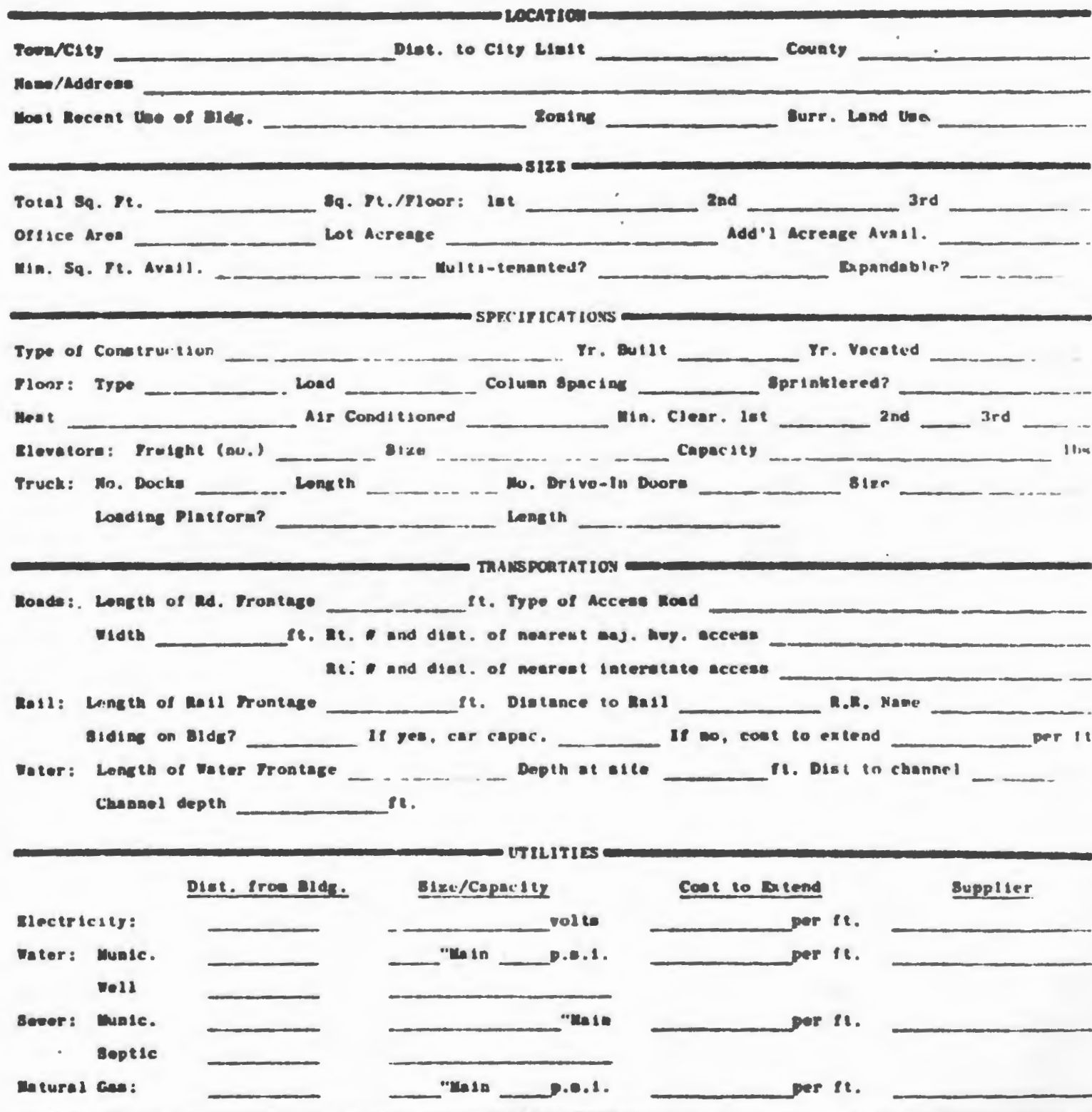

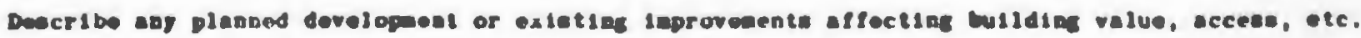

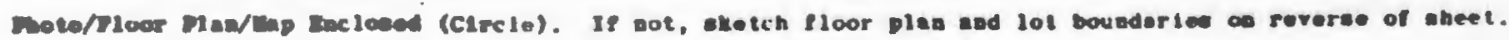



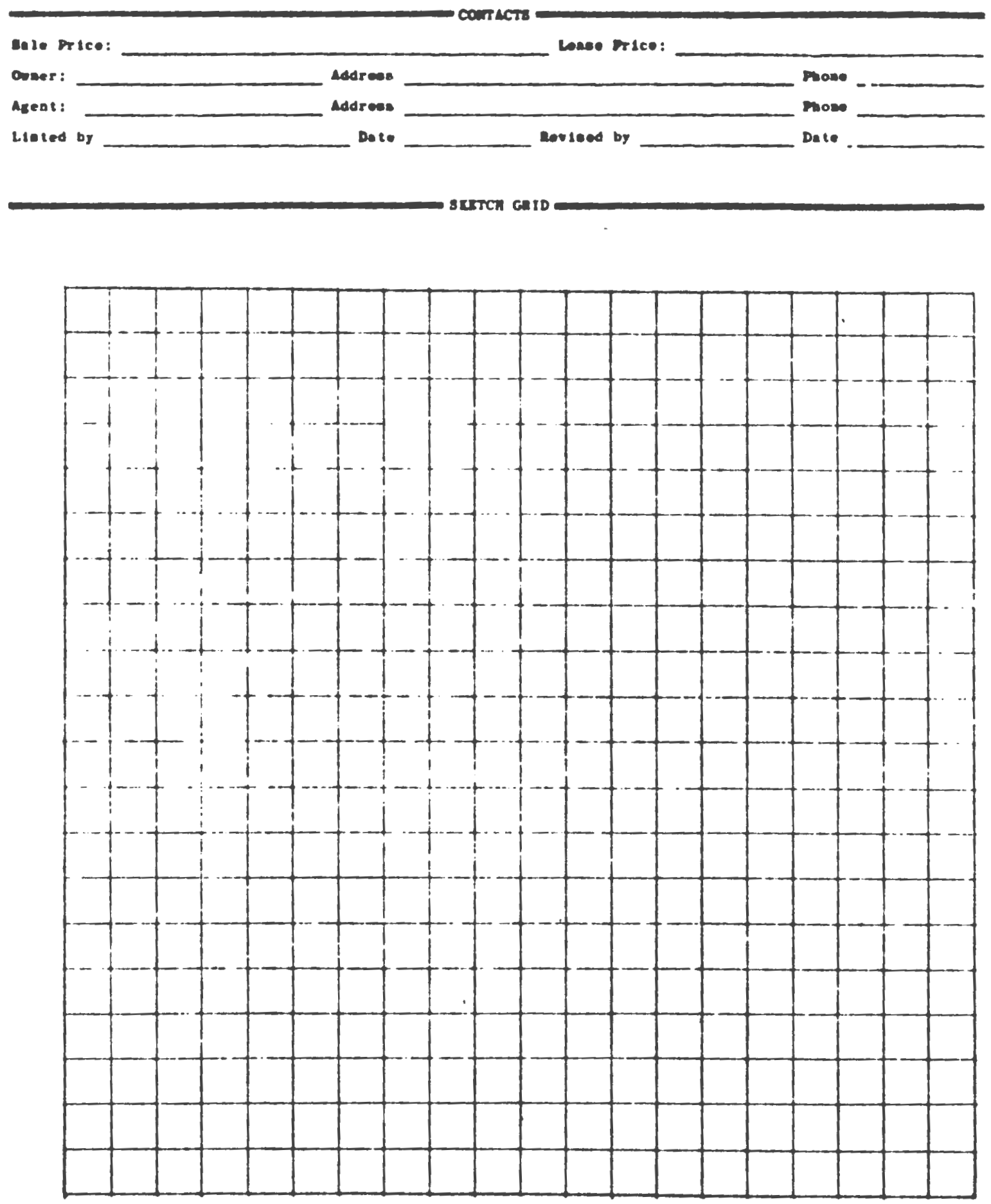
PLANT REQUIREMENTS CIECKLIST

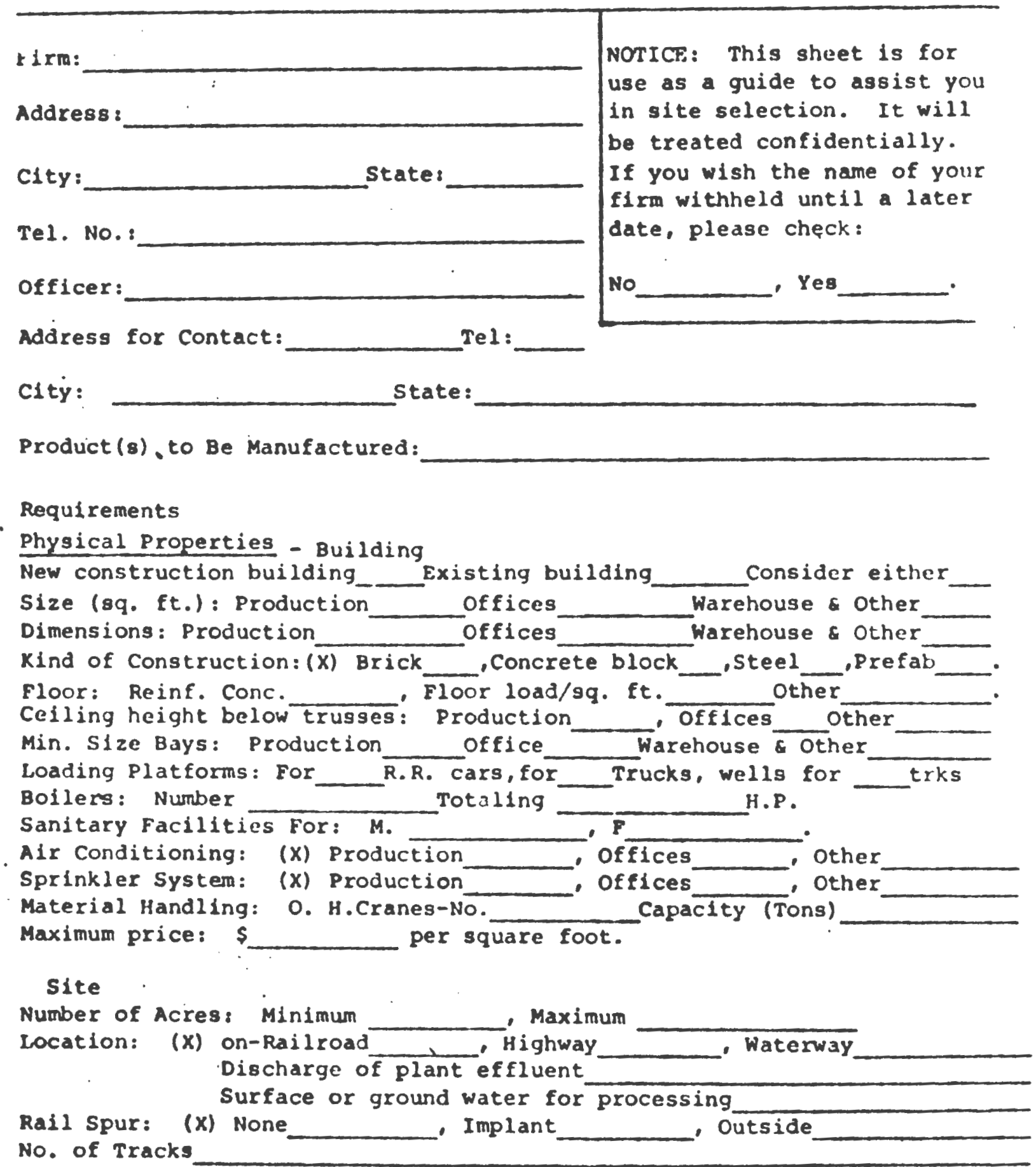


PLANT REQUIREMENTS CHECRLIST

\section{continued}

Ut111ties

$$
\text { Electric }
$$

Type of service:

Max. demand: $\mathbf{X W}$

Metering desired: $(X)$ Secondary

- Volts

Phase Krin,L.I. Primary

Puel

Type of service: (X) Natural Gas Interruption tolerance: (houra) .011 - L.P. Gas other

Monthly consumption:/unit of measure: Heating Type of gas contracts (x) Interruptable - Proceseing - Non-interruptable

\section{Water}

Avallability from: (X) Mulclpal _. Wells_., Surface _. Impounded Fst.quantity: Sanitary Chemical tolerance acceptable: Analysis of plant waste:

\section{Transportation}

Service: $(x)$ Rail Motor Carrier

Est. Annual Tonnage: Inbound-Rail M.Gal./Mo.Processing H.G.D. (or M. G./mo)

\section{Outboard-Rail}

Points of origin(annual tons) from: Ar - Truck - Truck Water-Importe Water water

\section{Personnel}

Adminiatration c office: Male Production: Initially-Male - Pemale Classiflcation: Sk1lied -Female, One-Year-Male special skills: Semi-sk111ed - Unskilled Temale Training program desired:

\section{Financing}

Est. Investment: Physical properties-\$ - Equip. $-\$$ ,other Financing Req.: $(x)$ None Land c Buildings Type of lease--if financed: (X) straight lease other Lease purchase

Term of lease deslred--years:

Area

Geographic Area Desired

Cornmunity size Desired:

Special or Personal Requirements: 
SURVEY OF LOCAL MANUFACTURERS

$-128-$ 


\section{METHODOLOGY}

A Iist of Central Falls' manufacturers was compiled from the Manufacturers' Directory published by the Blackstone Valley Chamber of Commerce. The Iarge number of firms (74) located in Central Falls precluded visiting each firm personally. A mail survey was agreed upon due to the amount and complexity of the data to be collected. A letter of introduction was mailed to every firm from the Mayor's Office defining the project and assuring them that the results would be held in strictest confidence. The survey instrument was designed with the assistance of Ms. Christine Howells of the Bureau of Government Research at the University of Rhode Island. The questionnaires were mailed out with a cover letter and a stamped, addressed return envelope to the President or Chief officer of each firm. Copies of the questionnaire and related mailings are included in the Appendix.

The firms participating in the survey took from two to four $(2-4)$ weeks to return the questionnaire. This lag time was attributed to the timing of the survey, July being a month when many factories close down. The response rate of $67.5 \%$ is considered excellent for a mail survey and should provide a reliable profile of the manufacturing community in Central Falls. 
Statistical analysis of the results consists of frequency tables for the responses to each question. Responses are reported in raw numbers and percentages. In those cases where respondents were required to prioritize certain items, the results were ranked according to the frequency of each response category. A detailed description and analysis of the responses to each question follows:

\section{SAMPLE QUESTIONNAIRE}

Name of Firm:

We would like to begin by asking some general questions about your firm.

1. What is the major product of your firm? (Check One)

Food Products

Textiles

Appare1
Metals \& Machinery Jewelry \& Silverware Other (Please specify)

2. Approximately what is your gross yearly sales volume? (Check One)

Under $\$ 15,000$

$\$ 15,000-24,999$ $25,000-49,999$
$\$ 100,000-\$ 499,999$

$500,000-999,999$

Over $\$ 1,000,000$ 
3. Where is the market for the products your firm manufactures? (Estimate the percentage of sales in each area)

Local (Within R.I.)

Regional (Southeastern, N.E.)

$\begin{array}{ll}{ }_{2} & \text { National } \\ \text { International } & \text { TOTAL }\end{array}$

4. How many people do you employ?

a. How many full-time employees?

b. How many part-time employees?

5. Estimate the percentage of employees of your firm from the following municipalities:

MUNICIPALITY

Central Falls

Pawtucket

Lincoln

Cumber 1 and

Other
PERCENTAGE

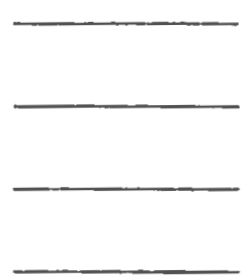

TOTAL $100 \%$

6. How many seven (or eight) hour shifts per day does your plant operate?

Please complete the following table:

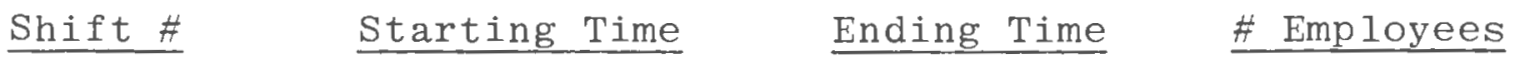


7. The Labor Force can be divided into four (4) categories: professional, craftsman, operative, and laborer. Within each of these four (4) categories, record how many workers of each type you employ in the right-hand column.

PROFESSIONAL

Managers

Administrators

Sales Persons

Clerks

CRAFTSMAN

Mechanics \& Repairman

Metal Molders

Pattern \& Model Makers

Plumbers

Sheet Metal Workers

Electricians

Tool \& Die Makers

OPERATIVES

Assemblers

Cutters

Dressmakers

Dyers

Filers

Polishers

Metal Platers

Packagers

Wrappers

Welders \& Flame Cutters

Textile Operatives

LABORERS

Warehousemen

Cleaners \& Vehicle Washers

Service Workers (Janitors)
\# OF WORKERS

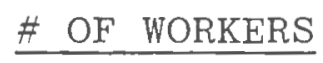

\# OF WORKERS
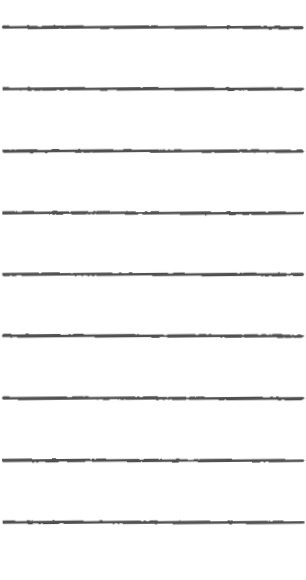

\# OF WORKERS 
Now, we would like to ask you some questions about the site on which you are located.

8. How old is the building in which you are located?_Yrs.

9. Do you own or lease this building? Own Lease

10. Is your firm the only occupant of the building? Yes No

11. What is the total amount of space available to your firm (Your Firm Only)?
In Use
Available, Unused

sq. ft. $\mathrm{sq} \cdot \mathrm{ft}$.

$\therefore \quad$ Please complete the following table:

\begin{tabular}{|l|l|l|}
\hline & & Area/Sq. Ft. \\
\hline TYPE OF SPACE & IN USE & AVAILABLE, HSED \\
\hline Manufacturing & & \\
\hline Storage & & \\
\hline Shipping/Receiving & & \\
\hline Parking & & \\
\hline
\end{tabular}

12. We would like to know if the building (s) you occupy are adequate for your current operations. This information could be used to apply for federal assistance for site and building improvements. For each of the following items, please indicate whether you believe it is a severe need, a moderate need, or not a need at this time. (Circle only 1 answer in each line).

a. More Floor Space

Severe Mod. Not a Not Need Need Need Sure

b. Greater Loading Capacity of floors

1

2

3

c. Improved Shipping/Receiving facilities 


$\begin{array}{llll}\begin{array}{l}\text { Severe } \\ \text { Need }\end{array} & \begin{array}{l}\text { Mod. } \\ \text { Need }\end{array} & \begin{array}{l}\text { Not A } \\ \text { Need }\end{array} & \begin{array}{l}\text { Not } \\ \text { Sure }\end{array}\end{array}$

d. More efficient heating system

1

e. Electrical wiring improvements

f. Greater sewer systems improvement

g. Other (please specify)
1

1

1
2

2

2

2
3

8

8

8

8

13. The following is a list of possible problems you might encounter in running your operation. For each item, please indicate whether you believe it is a severe problem, a moderate problem, a small problem, or not

a problem at all. (Check only 1 answer in each line):

\begin{tabular}{llll} 
Severe & Mod. & Minor Not A Not \\
Problem & Problem & Prob. & Prob. \\
\hline
\end{tabular}

a. Poor access to

loading dock for

shipping/receiving

1

2

3

4

8

b. Traffic congestion in

the vicinity of the

plant

1

2

3

4

8

c. Inadequate parking

for employees

1

2

3

4

8

d. Narrow width of the

roadway

1

2

3

4

8

e. Too many cars parked

along the street

1

2

3

4

8

f. Other (please specify) 1

2

3

4

8

14. From the list of alternatives below, check the statement that best reflects your moving and expansion plans during the next five (5) years:

Move to another location and maintain the plants current size.

Move to another location and increase the plants size. 
Open another plant at another location in addition to the existing one.

Expand the size of the existing plant at the present location.

Maintain the current plant size at the present location.

14a. How strong are your intentions?

Very strong Moderately strong

Not Too Strong

14b. If you have plans for moving and expanding, do you have any potential locations in mind?

Yes
(1) If Yes, Where? $\quad$ Be as specific as possible.

15. We would like your suggestions as to how the city can offer support for your business operation. Please number in order of importance those activities listed below which you would like to see the city undertake: ( 1 - Most important, 6 - Least important)

Assist you in making contacts with local, state, and federal funding sources.

Identify available sites and buildings for possible relocation and expansion.

Work with appropriate agencies to organize promotional activities.

Analyze traffic circulation problems and recommend improvements.

Provide technical assistance in meeting federal, state, and local regulations.

other (Please specify)

To help make the results of this survey more meaningful, any additional comments you wish to make on the back of this page will be most welcome. Please use the enclosed stamped, addressed envelope to return the questionnaire. Thank you. 

ANALYSIS OF RESULTS

Question 1: Major products of your firm

The results to this question indicate that $32 \%$ of the firms in Central Falls manufacture fabricated metals and machinery. The second largest manufacturing group is the textile industry, consisting of $22 \%$ of the city's firms. The third highest percentage of firms is involved in the manufacture of food products ( $16 \%$ ). The remaining $30 \%$ of the city's firms shows great diversity in terms of the type of products they manufacture, as is clearly seen in Table 10 .

While the highest percentage of firms manufacture metals and machinery, the textile and apparel industries employ the most people, a total of over 1,500 workers. This figure represents approximately $44 \%$ of the total number of workers employed by the city's manufacturing firms. Thus, Central Falls continued to depend heavily on the textile industry for tax revenues and employment. A signifigantly high percentage of persons are employed in glass products $(19.1 \%$ - 650) and metals and machinery (17.9\% 607). Thus, four of every five persons that work for Central Falls manufacturing firms do so in the categories named above, with the remaining $20 \%$ distributed among a variety of manufacturers (food products, jewelry, and silverware, etc.). 
TABLE 10

Question No. 1 - Major Products

\section{Type}

Food Products

Textiles

Apparel

Metals and Machinery

Jewelry and Silverware

Other:

Photofinishing

Plastics

Woodworking

Chemicals

Glass Products

Juvenile Accessories

TOTALS

\begin{tabular}{r} 
Firms \\
\hline 8 \\
11 \\
1 \\
16 \\
4
\end{tabular}

\begin{tabular}{l}
1 \\
2 \\
3 \\
2 \\
1 \\
1 \\
\hline 50
\end{tabular}

$\frac{\%}{16}$

22

2

32

8

2

4

6

4

2

$\frac{2}{100 \%}$

\begin{tabular}{c} 
\# of Employees \\
\hline 279 \\
765 \\
750 \\
607 \\
140
\end{tabular}

\%

8.2

22.5

22.0

17.9

4.1

0.9

0.4

0.1

0.4

19.1

$\frac{3.5}{100 \%}$ 
Examination of the results indicates that Central Falls' industrial base is diversified. Industries in this city manufacture machinery and related components, textiles, glass products, food products, jewelry and silverware, wire, wood products, chemicals, and many other items.

For a city which has been historically dependent upon one industry, the diversity of the present industrial base is in the city's best economic interests.

\section{Question 2: Annual Sales Volume}

A surprisingly high percentage (38\%) of the city's manufacturers have a gross yearly sales volume of over $\$ 1$ million. Table 11 indicates that $58 \%$ of the city's firms do over $\$ 300,000$ worth of business per year, and $88 \%$ over $\$ 100,000$. These figures are surprising when one considers that $60 \%$ of the firms located in the city employ less than 25 persons. These results are explained by the fact that the majority of the firms export their products outside Rhode Island, and many have national markets for their products. With today's high operating costs, it is encouraging that such a high percentage of firms have a large sales volume. It is recommended that these results be followed-up to determine those manufacturing groups that do the highest sales volume and which products bring the highest rate of return. 
TABLE 11

Question No. 2 - Sales Volume

Under $\$ 15,000$

$\begin{array}{rr}\frac{\mathrm{N}}{0} & \frac{\%}{0 \%} \\ 1 & 2 \% \\ 3 & 6 \% \\ 15 & 30 \% \\ 10 & 20 \% \\ 19 & 38 \% \\ 2 & 4 \%\end{array}$

$\mathrm{N} / \mathrm{A}$

$\$ 15,000-\$ 24,999$

$\%$

$\$ 25,000-\$ 49,999$

$6 \%$

$\$ 100,000-\$ 499,999$

$0 \%$

$\$ 500,000-\$ 999,999$

$0 \%$

Over $\$ 1,000,000$

$38 \%$

$4 \%$

Question No. 3: Market Area for Products

Economic base theory asserts that there are two kinds of industries. One group exports its products and services outside its region; these are returned to the region in the form of money. The money brought into the region by the export (basic) industries contributes to the growth of industries (non-basic) which produce for local consumption. As a region's boundaries are extended either through actual growth or arbitrary selection, export sales for the original industries tend to decrease and more sales occur within the region.

of course, any theory has its flaws, and economic base theory is not without exception. Review of the survey results indicates that few industrial establishments produce exclusively for out-of-region or for local markets. 
Therefore, to place industries in either basic or nonbasic categories is an oversimplification which is not supported by actual market behavior.

Time constraints and the manufacturer's desire for privacy have presented a more thorough application of economic base theory to the market situation in Central Falls. The underlying principals of economic base theory has been applied, however, to gain some understanding of the distribution of products manufactured in Central Falls. If Rhode Island is defined as the region, with all sales outside the state designated export sales, $60 \%$ of the city's industrial establishments are basic, while just $12 \%$ ( 6 firms) are non-basic.

If the region's boundaries are extended to include all of Southeastern New England, with all sales outside the region considered export sales, $40 \%$ of the city's manufacturers are engaged in basic activities, while $22 \%$ are non-basic and distribute their products within the region. This fits with economic base theory, which states that export sales tend to decrease as a region's boundaries are extended.

On the average, $48 \%$ of all products manufactured in Central Falls are distributed nationally, $23 \%$ are distributed regionally (throughout Southeastern New England), $26 \%$ are manufactured for distribution within Rhode Island, 
and only $3 \%$ of all the products are distributed internationally. If this data is aggregated, $74 \%$ of all products manufactured in the city are marketed outside Rhode Island. As cited above, $60 \%$ of the city's firms do over $90 \%$ of their business outside Rhode Island. One can conclude that a significant majority of the city's firms rely on export markets and that a large part of Central Falls' industrial base is influenced as much by national economic trends as local economic conditions. Therefore, Central Falls' industry brings new money into the Blackstone Valley and contributes to its economic stability and growth. However, because of this dependence on export markets, many firms are not tied to a location in Central Falls. It is significant to note that $46 \%$ of the city's firms have no sales within Rhode Island, and $38 \%$ have no sales in Southeastern New England.

Question 4: Number of Employees (full or part-time) Central Falls' industrial base is largely made up of small firms employing less than 25 persons. $60 \%$ of the city's firms fit this category. Another $26 \%$ can be categorized medium-sized, employing 26-100 persons. According to the survey, only $12 \%$ employ over 100 workers. (See Table 12) 
TABLE 12

Question No. 4-No. of Employees (full or part-time)

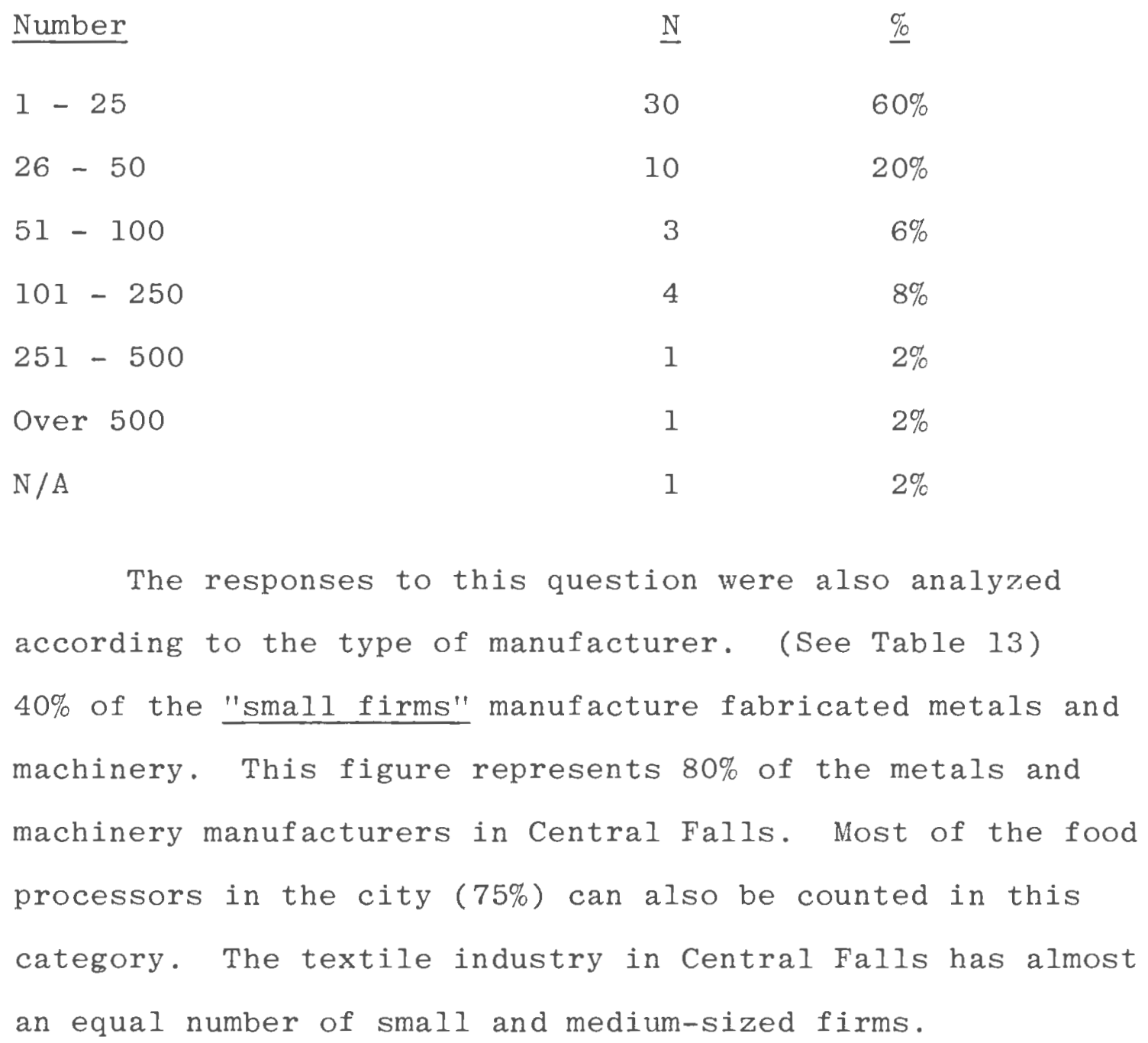


TABLE 13

Question No. 4 - No. of Employees VS. Type of Firm

Type of Firm

No. of Employees

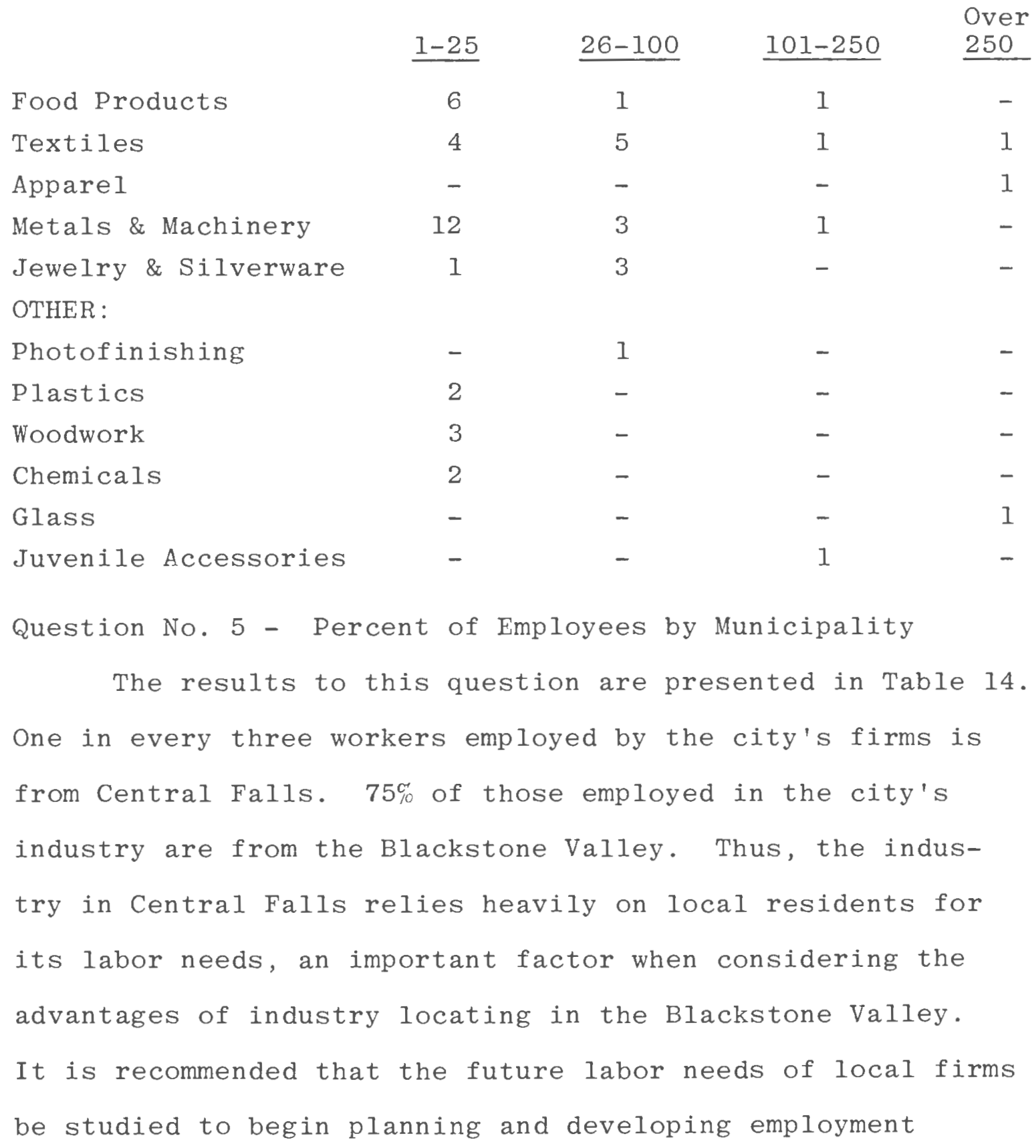


training programs for local residents. As mentioned earlier, the creation of jobs has multiple economic benefits for a community. The placement of Central Falls residents in jobs in local industry could do much to improve the standard of living in Central Falls. Question No. 5 - \% of Employees by Municipality

City/Town

Central Falls

Pawtucket

Lincoln

Cumberland

other

Number $=2,565$ (employed by 49 firms)

Question 6: Percent of Employees per Shift
Nightshift - any shift between 4 P.M. and 12 A.M.

Morningshift - any shift between 11 P.M. and 7 A.M. TABLE 15

$\underline{\text { Shift }}$

Dayshift

Nightshift

Morningshift

TOTAL $N=2,160$ ( 47 firms)

As can be seen from Table 15, approximately $86 \%$ of

those employed by local firms work between 7 A.M. and 5 P.M. A considerably smaller percentage ( $12 \%$ ) work between 4 P.M. 
and 12 A.M., and only 2.5\% of the city's industrial workers work between $12 \mathrm{~A} . \mathrm{M}$. and $7 \mathrm{~A} . \mathrm{M}$. One can infer from these figures that the majority of firms run one shift, or the major part of their production is during normal work hours.

Question 7: Classification of Labor Force

The results to this question show the ratio of skilled to unskilled workers in local industry is $8: 1$. A percentage breakdown shows the percentage of skilled and semi-skilled workers to be $70 \%$. The professionals represent the next highest group with $21 \%$ of the manufacturing labor force. Unskilled workers or laborers make up a small percentage $(8 \%)$. The majority of positions are to operate the machinery in the textile and machinery industries. These jobs require six (6) months to a year of training and call for an average starting salary ranging from $\$ 2.64$ to $\$ 4.00$ per hours.

Question 8: Age of Building

This question was asked to see the age distribution of existing industrial facilities in Central Falls. Since the city has very little open space for development, the age and condition of existing factories is important when considering the potential for industrial growth in Central Falls. Looking at Table 16, one can see that a significant portion ( $44 \%$ ) of the city's factories are over fifty (50) years old. While some may have been properly maintained 
over the years, others are in need of renovation. The renovation of some structures may not be a good investment, however. The acquisition and/or demolition of these structures could provide open space needed for redevelopment. It might also be noted that $10 \%$ of the respondents indicated they occupied structures that were over one-hundred (100) years old. These distinctive mill structures are reminders of Central Falls' historic past, and the feasibility of preserving them should be strongly considered. These buildings are commonly underutilized, perhaps due to their inability to accommodate heavy industry. The possibility of adapting these old mills for other use, be that light industrial or commercial, would increase their marketability and in turn provide jobs and tax revenues for the community. The age distribution of manufacturing buildings is presented in the following table:

TABLE 16

Question No. 8 - Age of Buildings Age Category (years)

$1-25$

$\begin{array}{rl}\frac{\mathrm{N}}{11} & \frac{\%}{2} \\ 9 & 22 \% \\ 17 & 18 \% \\ 5 & 34 \% \\ 8 & 10 \% \\ 50\end{array}$

TOTAL 
Question No.9-Occupant Own/Lease

$\begin{array}{lrr}\text { Own } & \frac{N}{29} & \frac{\%}{58 \%} \\ \text { Lease } & 19 & 38 \% \\ \text { N/A } & 2 & 4 \%\end{array}$

The results show that $58 \%$ of the firms surveyed own the building (s) they occupy, while $38 \%$ of the firms lease. A clear majority of firms in Central Falls have a substantial investment in the city.

The costs of moving to the suburbs are high, some of which are as follows:

--moving machinery, files, furniture, etc.,

--non-salvable equipment must be junked

--new supplies and subcontractors found

-new employees hired

--separation costs to long-service employees

Therefore, it is likely that most of them will remain in Central Falls and continue to represent a significant resource to the community in the form of employment, tax revenues, and potential economic growth. It is clear then, that their needs and problems must be addressed for any successful effort to revitalize the economy in Central Falis.

As mentioned previously in this report, the manufacturing community represents an important resource to Central Falls, and therefore the needs and problems of this element of the economy must be addressed. Questions 12 
through 15 were included in the survey to provide the city's manufacturers with the opportunity to describe their needs and problems, to indicate whether they had any plans for relocation and/or expansion, and to offer some suggestions for municipal economic development activities.

Question 12: Needed Building Improvements

Table 18 provides a detailed description of the kinds of physical improvements for which area manufacturers expressed a need. The responses to this question were ranked according to the frequency of response, with the point value decreasing with the intensity of the need. (See Table 19) Improvements in shipping/receiving facilities received the highest ranking. This is not surprising when one considers the narrow streets and the antiquated design of many of the city's factories. This condition is very apparent along Roosevelt Avenue where many of the factories have loading docks located on the street. Presently there is two-way traffic on Roosevelt Avenue and parking along both sides of the street. These factors further complicate the shipping problem.

The second most frequently expressed need was for more floor space. Open space for industrial use is at a premium in Central Falls. In addition to selective acquisition and demolition of existing buildings, the need for 
floor space can be addressed by identifying vacant or underutilized manufacturing space in the city. In the course of this study, data was gathered on the amount and location of vacant manufacturing space available.* Survey results indicated the demand for manufacturing space far exceeds the amount of space available.

A third type of building improvement needed in many of the local factories is a more efficient heating system. Improvements under this heading include not only a more modern and efficient heating apparatus, but also roof repairs, blocking off windows, and additional insulation, all contributing to a more efficient heating of the buildings.

A fourth need expressed in the survey is greater loading capacity of the floors. Many of the mills in Central Falls have several stories. Those levels above ground level not only present materials-handling problems, but also lack the loading capacity to support the heavy machinery of modern industry. This problem is significant when considering the marketability of the space in many of the old mill buildings in the city.

*This data is contained in memo submitted to the Planning Director in July, 1978. 
TABLE 18

Question No. 12 - Needed Building Improvements

A. More Floor Space

Severe Need

Moderate Need

$\underline{N}$

$\underline{\%}$

Not a Need

Not Sure

No Answer

B. Greater Loading Capacity

Severe Need

Moderate Need

Not a Need

Not Sure

No Answer

C. Improved Shipping/ Receiving Facilities

Severe Need

Moderate Need

6

14

26

1

3

N

7

7

3

35

0

5

$\mathrm{N}$

8

11

27

Not a Need

Not Sure

No Answer

D. More Efficient Heating

Severe Need

0

4

$\underline{N}$

6

Moderate Need

13

Not a Need

28

Not Sure

0

No Answer

3

$12 \%$

$28 \%$

$52 \%$

$2 \%$

$6 \%$

\%

$14 \%$

$6 \%$

$70 \%$

$0 \%$

$10 \%$

\%

$16 \%$

$22 \%$

$54 \%$

$0 \%$

$8 \%$

\%

$12 \%$

$26 \%$

$56 \%$

$0 \%$

$6 \%$ 


$\begin{array}{lrr}\text { E. Electrical Wireing Improvements } & N & \frac{\%}{K} \\ \text { Severe Need } & 4 & 8 \% \\ \text { Moderate Need } & 8 & 16 \% \\ \text { Not a Need } & 33 & 66 \% \\ \text { Not Sure } & 0 & 0 \% \\ \text { No Answer } & 5 & 10 \% \\ \text { F. Sewer Systems Improvement } & \underline{N} & \frac{\%}{1} \\ \text { Severe Need } & 2 & 4 \% \\ \text { Moderate Need } & 2 & 4 \% \\ \text { Not a Need } & 39 & 78 \% \\ \text { Not Sure } & 8 & 16 \% \\ \text { No Answer } & 6 & 12 \% \\ \text { G. } & \mathrm{N} & \\ \text { Other } & 1 & \\ \text { Inadequate Power to Building } & 3 & \\ \text { Roof Repairs } & 2 & \\ \text { Paint Building } & 1 & \\ \text { Heating Costs - blocking windows } & & \\ \quad \text { for heat efficiency } & 1 & \end{array}$

TABLE 19

Rank of Needed Building Improvements

\#1 - Improved shipping/receiving facilities

\#2 - More Floor Space

$\# 3$ - More efficient heating system

\#4 - Greater Loading Capacity of Floors

\#5 - Electrical Wireing Improvements

\#6 - Sewer System Improvements

Building improvements and renovations in all forms are encouraging signs of a firm's stable investment in a community. It is a recognizable trend in federal urban planning policy to reinvest in urban areas by working with the private sector. The role of municipal government is to 
identify economic development programs and work with private investors and government representatives to obtain financial assistance to make these needed improvements. Such efforts would serve to demonstrate the city's commitment to economic revival and stimulate further investment of private capital in the community.

Question 13: Operating Problems

This question was asked to determine what operating problems, specifically traffic-related, the city's manufacturers are experiencing. On-street parking in the vicinity of the plant was mentioned most frequently. This condition impedes traffic flow and interferes with shipping and receiving activities in many cases. Poor access to the loading docks was the second most frequently mentioned problem, followed by inadequate parking for employees. These problems are predictable in a densely populated area such as Central Falls. The majority of the city's roadways were built prior to 1900 and not designed for today's traffic demands.

The feasibility of eliminating on-street parking in manufacturing areas of the city should be examined, along with the possibility of organizing cooperative efforts to provide parking for employees. In the meantime, greater cooperation is required from the police department to regulate parking violations. The following table (Table 20) 
provides a description of the frequency and distribution of responses to Question 13.

TABLE 20

Question No. 13 - Operating Problems

$\begin{array}{lrr}\text { A. Poor Access to Loading Dock } & \frac{\mathrm{N}}{7} & \frac{\%}{-} \\ \text { Severe Problem } & 11 & 22 \% \\ \text { Moderate Problem } & 7 & 14 \% \\ \text { Minor Problem } & 23 & 46 \% \\ \text { Not a Problem } & 2 & 4 \% \\ \text { No Response } & \end{array}$

B. Traffic Congestion in Plant Vicinity $N$ \%

Severe Problem $\quad 5 \quad 10 \%$

Moderate Problem $\quad 10 \quad 20 \%$

Minor Problem $\quad 9 \quad 18 \%$

Not a Problem $\quad 24 \quad 48 \%$

$\begin{array}{lll}\text { Not Sure } & 0 & 0 \%\end{array}$

No Response $\quad 2 \quad 4 \%$

C. Inadequate Parking for Employees $\quad$ N

Severe Problem $\quad 9 \quad 18 \%$

$\begin{array}{lll}\text { Moderate Problem } & 6 & 12 \%\end{array}$

$\begin{array}{lll}\text { Minor Problem } & 7 & 14 \%\end{array}$

$\begin{array}{lll}\text { Not a Problem } & 27 & 54 \%\end{array}$

$\begin{array}{lll}\text { Not Sure } & 0 & 0 \%\end{array}$

$\begin{array}{lll}\text { No Response } & 1 & 2 \%\end{array}$

D. Narrow Width of Roadway $\quad$ N

Severe Problem $\quad 5 \quad 10 \%$

$\begin{array}{lll}\text { Moderate Problem } & 10 & 20 \%\end{array}$

$\begin{array}{lll}\text { Minor Problem } & 7 & 14 \%\end{array}$

Not a Problem $\quad 23 \quad 46 \%$

$\begin{array}{lll}\text { Not Sure } & 1 & 2 \%\end{array}$

No Response $\quad 4 \quad 8 \%$ 
E. On-Street Parking

Severe Problem

\begin{tabular}{rr}
$\frac{\mathrm{N}}{8}$ & $\underline{\%}$ \\
11 & $16 \%$ \\
6 & $22 \%$ \\
19 & $12 \%$ \\
1 & $38 \%$ \\
5 & $2 \%$ \\
$\mathrm{~N}$ & $\underline{\%}$ \\
\hline 3 & $6 \%$ \\
1 & $2 \%$ \\
1 & $2 \%$ \\
1 & $2 \%$
\end{tabular}

Rank of Business Operating Problems

\#1 - On-street parking in vicinity of plant

\#2 - Poor access to loading dock for shipping/receiving

\#3 - Inadequate employee parking

\#4 - Traffic congestion in vicinity of plant

\#5 - Narrow width of roadway

Question 14: Moving and Expansion Plans

While $50 \%$ of the firms surveyed indicated they are maintaining the current plant size at the present location, several firms have plans for expansion. The results are as follows:

$-24 \%$ ( 12 firms) have plans to expand the size of the existing plant at the present location

$-16 \%$ ( 8 firms) have plans to move to another location and increase the plant's size $--16 \%$ ( 8 firms) have plans to open another plant at another location in addition to the existing one. 
Of those firms that have moving and/or expansion plans:

--14 firms have no potential location in mind - 7 firms do have potential locations

- a smaller number have revealed that they are actually moving out of Central Falls.

From this data, we can make certain inferences about the relocation and expansion plans of the manufacturing community. Approximately $80 \%$ of the firms surveyed plan to remain in Central Falls and maintain their current size, expand at the existing site, or open an additional plant, keeping the current plant in operation. A considerable smaller percentage, approximately $15 \%$ of the city's firms have relocation plans, and therefore, pose a potential threat to the local economy.

\section{Question 15: Suggestions for City Support}

This last question was asked to determine the kind of support the manufacturing community would like from the city. Many of these suggestions are offered as possible solutions to the needs and problems described earlier. The most frequently mentioned suggestion was for the city to assist in identifying available sites and buildings for possible relocation and expansion. The second most frequent 
request for the city to assist manufacturers is making contacts with government funding sources. Thirdly, the manufacturing community requested that the city provide technical assistance to help them meet government regulations. The responses to this question are detailed in Table 21.

\section{TABLE 21}

Question No. 15 - Suggestions for City Support

A. Assist in making contacts with government funding sources

$\begin{array}{lrr} & \underline{\mathrm{N}} & \underline{\%} \\ \text { Most important } & 10 & 20 \% \\ \text { 2nd most important } & 2 & 4 \% \\ \text { 3rd most important } & 5 & 10 \% \\ \text { 2nd least important } & 6 & 12 \% \\ \text { least important } & 9 & 18 \% \\ \text { No answer } & 18 & 36 \%\end{array}$

B. Identify available sites and buildings for possible relocation and expansion.

Most important

2nd most important

3rd most important

2nd least important

least important

No Answer

$\begin{array}{rr}\frac{\mathrm{N}}{\%} & \frac{\%}{-} \\ 12 & 24 \% \\ 5 & 10 \% \\ 0 & 0 \% \\ 12 & 12 \% \\ 15 & 24 \% \\ & 30 \%\end{array}$


C. Work with appropriate agencies to organize promotion activities.

Most important $\underline{N} \quad \underline{q}$

2nd most important $36 \%$

3 rd most important $4 \quad 8 \%$

2nd least important

$4 \quad 8 \%$

least important

$7 \quad 14 \%$

No Answer

$1948 \%$

D. Analyze traffic circulation problems and recommend improvements

Most important

2nd most important

3 rd most important

2nd least important

least important

No Answer

$\begin{array}{rr}\mathbf{N} & \frac{\%}{\%} \\ 6 & 12 \% \\ 4 & 8 \% \\ 2 & 4 \% \\ 6 & 12 \% \\ 14 & 28 \% \\ 18 & 36 \%\end{array}$

E. Provide technical assistance in meeting federal, state, and local regulations

Most important

2nd most important

3 rd most important

2nd least important

least important

\begin{tabular}{rr}
$\mathrm{N}$ & $\frac{\%}{\%}$ \\
\hline 8 & $16 \%$ \\
4 & $8 \%$ \\
5 & $10 \%$ \\
10 & $20 \%$ \\
18 & $36 \%$
\end{tabular}

F. Other Suggestions

Better enforcement of traffic laws, especially dealing with parking violations

Police protection against vandalism 
F. Other Suggestions

Reduce taxes on real estate and reduce unemployment insurance

Prohibit private solicitors

from canvassing

Rank of Suggestions for Government Assistance

\#1 - Identify available site and buildings for possible relocation and expansion

\#2 - Assist in making contacts with government funding sources

\#3 - Provide technical assistance in meeting government regulations

\#4 - Analyze traffic circulation problems and recommend improvements

\#5 - Work with appropriate agencies to organize promotional activities 
CENTRAL FALLS MANUFACTURERS AND PROCESSORS

Employment Code

\begin{tabular}{|c|c|}
\hline Letter & No. Employee \\
\hline A & $0-49$ \\
\hline B & $50-99$ \\
\hline $\mathrm{C}$ & $100-249$ \\
\hline D & $250-499$ \\
\hline $\mathrm{E}$ & 500 - Over \\
\hline
\end{tabular}

NAME

Chasen Mfg. Co. Health-Tex, Inc. Rosal, Inc.
ADDRESS

471 Roosevelt Ave. 558 Roosevelt Ave. 1281 Broad Street

Chemical
Dytex Chem. Co. General Polymer, Inc. Shur-Az Chem. Mfg.
1280 High Street

59 Foundry

871 High Street
EMPLOYMENT CODE

A

E

A

A

A

A

Fabricated Metal Products

Amer. Clad Metals

Dexter Tool Co.

Whittet-Higgins Co.

521 Roosevelt Ave.

B

1 Crown Point Road

33 Higginson Ave.

417 Roosevelt Ave.

10 Cross Street

59 Foundry Street

Ocean State Cable Co.

Swanezy Tool

A

A

\section{Food and Kindred}

Central Beverage Co.

500 High Street

Nissen Baking Co.

817 Dexter street

Royal Sausage Co.

166 Tremont Street

Ratty \& Sons Catering

781 Broad Street

Sackal's Bakery

C.F. Provision Co.

847 High Street

Wilk's House

468 High Street

L. B. Thomsen, Inc.

Furniture and Fixtures

Kenmore Venetian Bline 635 Roosevelt Avenue

A

Nursery Originals, Inc.

280 Broad Street

B

143 Washington Street 
Jewelry

NAME

Charisma Creations

Emco $\mathrm{Mfg}$. Co.

Liberty Plating Co., Inc.

Sanford-White Co.

Dunn-Well Jewelry Co

$$
\begin{aligned}
& \text { ADDRESS } \\
& 486 \text { Broad Street } \\
& 14 \text { Chapel Street } \\
& 6 \text { Chace's Lane } \\
& 96 \text { Hadwin St. } \\
& 7 \text { Chace's Lane }
\end{aligned}
$$

\begin{tabular}{c}
$\begin{array}{c}\text { EMPLOYMENT } \\
\text { CODE }\end{array}$ \\
\hline$A$ \\
$A$ \\
$A$ \\
$A$
\end{tabular}

\section{Lumber and Wood Products}

Central Falls Mfg. Co. 120 Chestnut Street A

Hammart, Inc. 176 Washington St.

Pohlson Galleries, Inc. 547 Roosevelt Ave.

A

Standard Earrell Co.

877 High Street

\section{Machinery}

Allan-Tex Machinery Co. 111-129 High Street William Collins Co. 430 Central Street

Gowdy Reed Co.

Metal Spraying Co.

Gervais Harness Mfg. Co. 1211 High Street

Nixen Engineering Co. 79 Chestnut

Rand Material Handling 24 Central Street

Wardwe 1 Printing Publishing and Aliied Industries

Beau-Monte Press 1361 Broad Street A

Dennis Printing A 478 Dexter Street A

Hayle Printing \& Supply 882 Dexter Street A

Professional Scientific and Controlling Instruments

Harcourt Knitting Co. 131 Clay Street A

Brule Manufacturing Co. 125 Washington Street A

Rubber and Plastic Products

Band-age, Inc.

Shredded Foam Products

Technicote, Inc

\section{Glass Products}

Corning Glass Works

1193 Broad Street

Textiles

Central Braid and Rug

1420 Broad Street

1075 High Street

86 Tremont St.

Commonwealth Braid Co.

Crown Spinning Milis

Dawson Mfg. Co.

467 Roosevelt Ave.

462 Central street

Elizabeth Webbing Mills

Felipe Braid Co.

Imperial Textile Co.

521 Roosevelt Ave.

68 Hadwin Street

1359 Broad Street
325 Illinois street

900 Lonsdale Ave.
131 Clay Street

1304 High Street

Roosevelt Ave.
A

A

A

C

C

A

A

A

A

E

A

B

A

A

B

A

$\mathrm{C}$

B

A 


\section{Textíles}

NAME

Lawson-Hemphi11, Inc .

Leedon Webbing Co.

Lyon Fabrics Co.

Murdock Webbing Co.

Narragansett Braid Mills

Ocean state Lace Corp.

Spintex Corp.

Van Craft Knitting Mills

Richmond Concerting Co.

Carlton Mfg. Co.
1461 High Street

678 High Street

1152 High Street

Miscellaneous

Dorset Corp.

Emblem Supply Co.

International Accessories

Vanguard Case Co.

Hasbro Industries
ADDRESS

26 Hadwin Street

86 Tremont Street

409 Roosevelt Avenue

27 Foundry Street

161 Rand Street

430 Pine Street

66 Hadwin Street

EMPLOYMENT

CODE

A

A

A

C

A

B

B

A

A

131 Clay Street

15 Eben Brown Lane

Roosevelt Avenue

Roosevelt Avenue

Broad Street

TOTAL: $\quad 72$ 



\section{CENTRAL FALLS INDUSTRIAL PROFILE}

1. Total employment in Central Falls has increased slightly (approximately $10_{\%}^{\circ}$ ) over the last 20 years, while manufacturing employment decreased by approximately $4 \%$. Manufacturing still accounts for nearly $70 \%$ of all employment, but this percentage has shown a declining trend since 1960. (See Table 22)

2. Central Falls maintains a "blue collar" work force with $42 \%$ of employed workers listed as operatives as compared to the state total of $24 \%$. Conversely, the city has a significantly lower percentage of white collar employment in the professional sales and clerical occupations when compared to the state as a whole. (See Table 23)

3. Although Central Falls' reliance on textiles and apparel has been diminishing (loss of 18 firms over the last 30 years, Table 24), these industry groups still account for $55 \%$ of all manufacturing employment. The remaining manufacturing employment is spread among 15 other industries groups with Glass, Miscellaneous Manufacturing and Rubber and Plastics accounting for the major share. (See Table 25)

4. A review of the overall industrial mix in Central Falls over the last 30 years reveals a slight diversification of industry types, with the heavier losses in the textiles and machinery firms and largest gains in the Fabricated Metals, Rubber and Plastics, Lumber and Wood Products, Instruments and Electrical Machinery Industries. Despite this diversification, a good portion of the gains in manufacturing employment was in the city's textile and apparel firms. 
5. Over $75 \%$ of Central Falls' manufacturing employment is in industries whose average hourly earnings on a U.S. scale fall below the median for all industry groups. (See Table 26 for 1977 U.S. industry wage rates)

6. As illustrated above, Central Falls is heavily reliant on the manufacturing of non-durable goods a a major element of its industrial base. Textiles and Apparel have been the mainstay of the community throughout its history and still plays an extremely important role. Realistically, the city cannot continue to solely rely on this industrial mix if its to meet its goals of improving the economic conditions of its people and reindustrialization of its industrial base.

\section{TABLE 22}

AVERAGE ANNUAL TOTAL AND

MANUFACTURING EMPLOYMENT

IN CENTRAL FALLS $1960-1980$

\begin{tabular}{lcccc}
\hline $\begin{array}{c}\text { TOTAL } \\
\text { Firms }\end{array}$ & Employment & \# Firms & Employment & \%ola \\
\hline 388 & 5,601 & 75 & 4,443 & .79 \\
368 & 5,009 & 81 & 3,763 & .75 \\
347 & 5,243 & 79 & 3,822 & .73 \\
317 & 6,413 & 69 & 4,737 & .74 \\
330 & 6,139 & 72 & 4,255 & .69 \\
& & & &
\end{tabular}

Source: Rides 
TABLE 23

CENTRAL FALLS EMPLOYED WORKERS

BY BROAD OCCUPATIONAL CATEGORY

(1970 CENSUS)

\begin{tabular}{lrccc} 
& Number & \% of Total & State \%'s \\
\cline { 2 - 3 } Professional/Tech & 450 & 6 & 14 \\
Craftsmen/Foremen & 1,015 & 13 & 15 \\
Operatives & 3,198 & 42 & 24 \\
Managers/Officials & 266 & 4 & 7 \\
Sales \& Clerical & 1,371 & 18 & 24 \\
Other & 1,249 & 17 & 16 \\
TOTAL: & 7,549 & $100 \%$ & $100 \%$
\end{tabular}

TABLE 24

CENTRAL FALLS MANUFACTURING FIRMS

1950,1972 , and 1980

\begin{tabular}{lrrrr} 
& 1950 & 1972 & 1980 & $+\begin{array}{c}\text { Change } \\
1950-1980\end{array}$ \\
\cline { 2 - 5 } Food \& Kindred Products & 9 & 8 & 6 & -3 \\
Tobacco Mfg. & 1 & 0 & 0 & -1 \\
Textile Mili Products & 36 & 24 & 18 & -18 \\
Apparel & 4 & 3 & 4 & 0 \\
Lumber \& Wood Products & 1 & 1 & 3 & +2 \\
Furniture \& Fixtures & 1 & 3 & 2 & +1 \\
Paper \& Allied Products & 0 & 0 & 1 & +1 \\
Printing \& Publications & 1 & 4 & 3 & +2 \\
Chemicals \& Allied Prod & 2 & 3 & 1 & -1 \\
Petroleum Refining & 0 & 0 & 0 & 0 \\
Rubber \& Plastics & 0 & 3 & 4 & +4 \\
Leather Products & 1 & 0 & 1 & 0 \\
Stone \& Clay \& Glass & 1 & 1 & 1 & 0 \\
Primary Metals & 2 & 3 & 2 & 0 \\
Fabricated Metals & 2 & 7 & 10 & +8
\end{tabular}


TABLE 24 (Continued)

\begin{tabular}{|c|c|c|c|c|}
\hline & 1950 & 1972 & 1980 & $\begin{array}{l}+- \text { Change } \\
1950-1980 \\
\end{array}$ \\
\hline $\begin{aligned} \text { Machinery (exc. } & \text { elec.) }\end{aligned}$ & 12 & 11 & 3 & -9 \\
\hline $\begin{array}{l}\text { Electrical \& Elec- } \\
\text { tronic Machinery } \\
\text { Transportation Equip }\end{array}$ & -0 & 1 & 1 & +1 \\
\hline $\begin{array}{l}\text { ment Instruments } \\
\text { Miscellaneous }\end{array}$ & 0 & 2 & 2 & +2 \\
\hline Manufacturing & 10 & 6 & 10 & 0 \\
\hline TOTAL: & 83 & 80 & 72 & -11 \\
\hline
\end{tabular}

Source: 1950 - Directory of Manufacturers in Rhode Island (RIPIDC) - 1972 \& 1980 - Department of Employment Security

TABLE 25

PERCENT DISTRIBUTION OF

MANUFACTURING EMPLOYMENT

BY INDUSTRY TYPES IN

CENTRAL FALLS - MARCH, 1980

Industry Type

(SIC Code)

23 Apparel

22 Textiles

32 Stone \& Clay \& Glass

39 Miscellaneous

30 Rubber: \& Plastics

33 Primary Metals

34 Fabricated Metals

20 Food

35 Machinery

36 Electrical Machinery

38 Instruments

24 Lumber

26 Paper

25 Furniture

27 Printing

28 Chemicals

31 Leather
$\%$ of Total

Mfg. Employment

32

22

12

9

7

4

4

3

2

2

1

1

$<1$

$<1$

$<1$

$<1$

$<1$

Source: Rides 
TABLE 26

AVERAGE HOURLY EARNINGS OF U.S. PRODUCTION WORKERS

ON MANUFACTURING PAYROLLS, BY

MAJOR INDUSTRY GROUP - 1977

(BY HIGHEST TO LOWEST ORDER)

Petroleum \& Coal products

7.72

Primary Metal Industries

7.45

Transportation Equipment

7.18

Chemicals \& Allied Products

6.30

Ordnance \& Accessories

6.25

Machinery (Exc. electrical)

6.20

Printing \& Publishing

6.09

Paper \& Allied Products

5.92

Fabricated Metal Products

5.84

Stone \& Clay \& Glass

5.76

Tobacco Manufacturing

5.49

Electrical Equipment

5.34

Food and Kindred Products

5.34

Instruments \& Related Products

5.20

Rubber \& Plastics

5.12

Lumber \& Wood

5.06

Miscellaneous Manufacturing

4.34

Furniture \& Fixtures

4.30

Textile Mill Products

3.97

Leather Products

Apparel \& Other Textile Products

3.64

3.62

Median

Source: U.S. Department of Labor, Handbook of Labor Statistics, 1978 


\section{CENTRAL FALLS TARGETING STRATEGY}

1. Central Falls should encourage continued diversification of its industrial base with emphasis on the manufacturing of durable goods rather than continued heavy dependence on non-durable goods. Industries which are low energy consumers, non-polluters, and produce high growth/high value added goods should be targeted.

2. The city should encourage the location of smaller, "incubator" type firms which are likely to experience a greater rate of growth than the general economy. Dependence on these smaller firms will allow the city to withstand cyclical fluctuations in the economy better than its reliance on a small number of firms with large employment rolls. In addition, existing industrial space in the city is better-suited and probably more affordable for these smaller firms.

3. Examples of the types of industries the city should attempt to attract are listed below. These have been compiled specifically for the State of Rhode Island by an independent consulting firm who considered such factors as growth potential, production requirements, labor requirements, and physical plant needs.

Target Industries for Rhode Island $\quad$ SIC Code

Biological Products 2831 Medicinal Chemicals 2833

Pharmaceutical Preparations 2834 Medical Electronic Equipment 3693

Dental Equipment and Supplies 3843 
Target Industries for Rhode Island

Small and Medium Turbines

Two-Way Communications Equipment

Instruments for Measurement, Display and Control of Process Variables

Instruments for Measuring and Testing of

Electricity and Electric Signals

Laboratory, Scientific and Research

Instruments $\underline{\text { SIC Code }}$

3511

3662

3823

3825

3811

Additionally, Central Falls should attempt to take advantage of the high-tech boom in New England by targeting firms in the following SIC Classification:

3573 Electronic Computing Fquipment

3574 Calculating Machines

3679 Electronic Components

3691 Storage Batteries

5065 Electronic Parts and Equipment

Since the city and the state as a whole does not have an extensive source of engineers or electronic technicians highly desired by high-tech firms, the area may be best suited for subassembly work such as the manufacturing of electronic couplings, panel boards, etc.

4. These efforts should not be instituted at the expense of existing industry. The city should attempt to analyze the needs of existing firms and develop an overall plan of action to continue to make Central Falls a profitable area in which to do business. 
SBA's 503 PROGRAM

H I GHLI GHTS

* Provides 90\% Financing

* Interest Rates 1\% - 2\% below prime

* Applicable to both Industrial and Commercial Ventures

* Financing up to $\$ 1$ Miliion

ELIGIBLE ACTIVITIES

* New Construction

* Purchase of Old Buildings

* Purchase of Land

* Purchase of Capital Equipment

* Major Renovations and Improvements

\section{INELIGIBLE USES}

* Working Capital and Inventory

* Refinancing

* Residential Property

* Real Estate Development \& Speculation

* "Rolling Assets" (trucks, moveable machinery, etc.)

\section{REQUIREMENTS}

A Business must submit the following:

* Business Plan and 2 year projected operating statement

* Personal Financial Statements

* Balance Sheets for the last 3 years

* List of all outstanding debt

\section{SOURCES OF FINANCING}

* 50\% from Bank at Standard Rates

* $40 \%$ from SBA at Treasury Note Rates

* $10 \%$ from Business Equity 
The Ocean State Business Development Authority is a private, non-profit corporate partnership established and supported by business and government to encourage economic growth in the state.

\footnotetext{
$* * * * * * * *$
} 
The proposed Central Falls Mill District (Figures 63 and 64) contains a large concentration of architecturally and historically. importan: industrial structures. Its boundaries are drawn to in. clude the six original water-power privileges along Roosevelt Avenue created in 1823 and the stone dam constructed in 1863. Among the notable buildings within this proposed district are:

Stafford Mill Complex, 581 Roosevelt Avenue, 1824 and 1860 s.

P. swtucket Thread Manufacturing Company Mill, 527 Roosisvelt Avenue, 1825.

Central Falls Woolen Mill, 523 Roosevelt Avenue, 1870.

Pawtucket Hair Cloth Mili. 501 Hoosevelt Avenue, 1864.

Royal iveaving Mill, 471 Roosevelt Avenue, 1897.

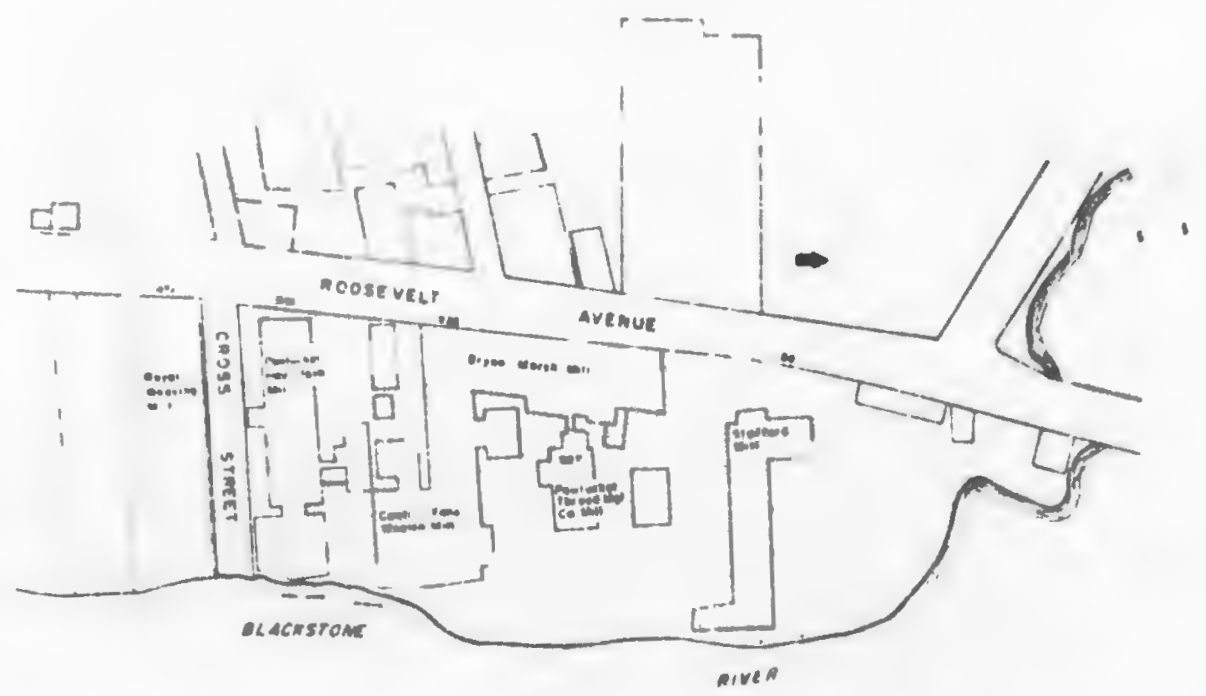

Proposed Central Falls Mill Historic District, National Register.

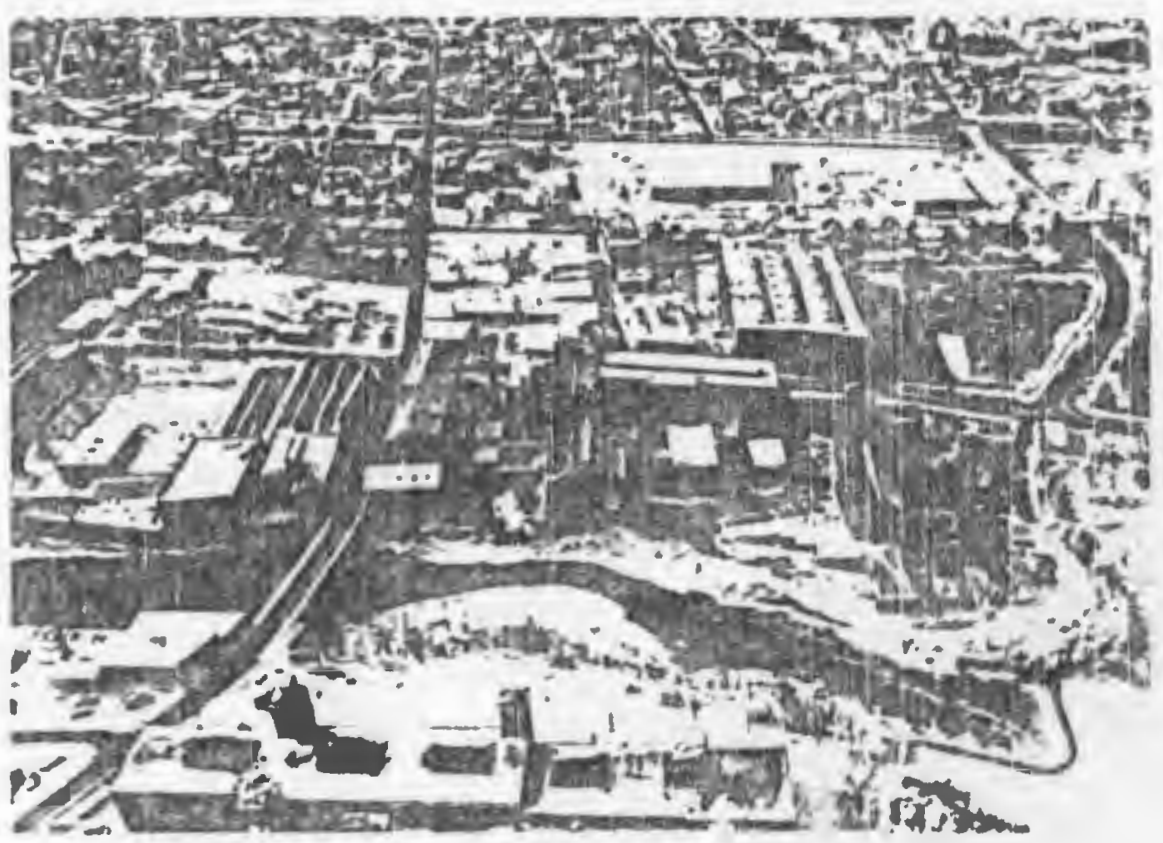

Aerial View of Proposed Central Falls Mill Historic District. National Register. 
BIBLIOGRAPHY 
Blackstone Valley Chamber of Commerce, An Inventory of the Status, Needs, and Potential of Industry to the Blackstone Valley. 1978 .

Bureau of National Affairs, Competing Successfully for Action Grants. Washington, 1980 .

Central Falls Welfare Department, Annual Report of The Department. Central Falls, 1978.

Congressional Record. Vol. 126. No. 196. June 12, 1980 .

Cornia, Gary C.; Testa, William A.; and Stocker, Frederick, D. State-Local Fiscal Imperatives and Economic Development. Academy of Contemporary Problems. Columbus, 1978.

Ewing, Reid. "A Development Program for the 80's, SBA's New Development Company Program". Commentary (a Publication of CUED). Vol. 5 No. 1. Washington, 1981.

Fernstrom, John. Bringing in The Sheaves - Effective Community Industrial Development Programs. U.S. Department of Agriculture. Washington, 1974.

Kennedy, Pamela. Central Falls, Rhode Island. Statewide Historical Preservation Report, P-CF-1. Rhode Island Historical Preservation Commission. Providence, 1978.

National Model Cities Community Development Director's Association. A Guide to Local Economic Development Planning and Implementation. Washington, 1976.

New England Municipal Center, Proceedings of New England Conference on Economic Development.

Providence Industrial Development Task Force. Final Summary Report. An Industrial Development Program for Providence, Rhode Island, 1979.

Rhode Island Department of Economic Development. Annual Report of the Research Division. Basic Economic Statistics. Providence, 1973, 1978, 1979, 1980. 
Rhode Island Department of Economic Development. Report of the Research Division. City of Central Falls, Rhode Island, Monograph. 1976.

Rhode Island Department of Education. Unpublished data. 1980 .

Rhode Island Department of Economic Development. Annual Report of The Research Division. Directory of Manufacturers. 1950, 1972, 1980.

Rhode Island Statewide Planning Program. Economic Development Strategy for Rhode Island. State Guide Plan. Element 211. 1979.

Rhode Island Statewide Planning Program. Land Zoned for Industrial Use: Inventory and Analysis. Technical Paper Number 76. 1978.

Schmenner, Roger W.; "Location Decisions of Large Firms, Implications for Public Policy". Commentary (a Publication of CUED). Vol. 5 No. 1. Washington, 1981.

Silverson, Donald. Survey of Local Manufacturers. Central Falls Division of Planning. 1978.

Small Business Administration. Loans to Local Development Companies. Washington, 1976 .

Starr, Richard E. "No. 1: Industrial Preservation". Nation's Cities. Vol. 16 No. 4. 1978.

U.S. Department of Housing and Urban Development. Action Grants: Revitalizing and Conserving Cities. HUD-CPD-541 (3). Washington, 1980.

U.S. Department of Housing and Urban Development and the National Community Development Association. Creating and Implementing an Economic Development Strategy. Washington, 1980 .

U.S. Department of Housing and Urban Development. Local Economic Development Tools and Techniques, A $\overline{\text { Guide- }}$ book for Local Government. HUD-PDR-483. 1979. 
U.S. Department of Housing and Urban Development. The Private Economic Development Process -

A Guidebook for Local Government. HUD-PDR-482. Washington, 1979 .

U.S. Department of Labor. Handbook of Labor Statistics. 1978. 